\title{
Sussumo Matsui
}

\section{MEDICINA E POLÍTICA:}

A polêmica de Platão com a medicina na República.

Brasília 


\section{Sussumo Matsui}

\section{MEDICINA E POLÍTICA:}

\section{A polêmica de Platão com a medicina na República.}

Dissertação apresentada ao programa de Pós-graduação em Filosofia da Universidade de Brasília, Linha de Pesquisa Filosofia Antiga e Medieval, como requisito parcial à obtenção do título de Mestre em Filosofia.

Orientador: Prof. Dr. Gabriele Cornelli

Brasília 


\section{Sussumo Matsui}

MEDICINA E POLÍTICA:

Polêmica de Platão com a medicina na República.

Dissertação apresentada ao programa de Pós-graduação em Filosofia da Universidade de Brasília, Linha de Pesquisa Filosofia Antiga e Medieval, como requisito parcial à obtenção do título de Mestre em Filosofia.

Orientador: Prof. Dr. Gabriele Cornelli

Prof. Dr. Gabriele Cornelli

Universidade de Brasília

Prof ${ }^{\mathrm{a}}$. Dr ${ }^{\mathrm{a}}$. Míriam Campolina Diniz Peixoto

Universidade Federal de Minas Gerais

Prof. Dr. Rodolfo Lopes

Universidade de Brasília

Brasília 
Dedico este trabalho à minha esposa, que soube compreender os meus momentos de ausência. 


\section{AGRADECIMENTOS}

Ao prof. Dr. Gabriele Cornelli pela confiança, pela infinita disponibilidade e por toda orientação na condução deste trabalho.

À prof ${ }^{\mathrm{a}}$. Dr ${ }^{\mathrm{a}}$. Míriam Campolina pelos conselhos e conversas que muito me ajudaram no amadurecimentodeste tema.

Ao prof. Dr. Silvio Marino, que mesmo estando na Itália, sempre me ajudou com as indicações bibliográficas e com os primeiros passos na tradição hipocrática.

À prof ${ }^{a}$. Dr ${ }^{\mathrm{a}}$. Agatha Bacelar, amiga, sempre gentil, alegre e presente.

À prof ${ }^{a}$. Dr ${ }^{\mathrm{a}}$. Loraine de Fátima Oliveira pelas muitas dicas e por estar sempre pronta a ouvir.

À CAPES pela bolsa concedida, pois sem esta seria impossível a realização deste trabalho. 


\section{RESUMO}

O fio condutor deste trabalho gira em torno da relação entre a filosofia platônica e a medicina. Em seu "nascimento", a medicina encontra diversas interfaces de diálogo com a filosofia também "nascente". Diversos comentadores se dedicaram a desvendar os percursos desta relação. Falar sobre a relação de Platão com a medicina exige que esse diálogo seja enquadrado no ambiente da polis dos séculos $\mathrm{V}$ e IV aEN, sempre em diálogo com os escritos hipocráticos. Ao contrário de Galeno e da tradição platônica, seguimos a hipótese que Platão estaria polemizando contra a medicina de sua época. Para demonstrar isso, voltamos à crítica de Platão à medicina "hipocrática" e suas respectivas consequências sociais na Grécia clássica. A hipótese desta dissertação é que Platão teria sido um conhecedor das teorias médicas da sua época e, atacando as novas correntes terapêuticas nascentes, se posiciona a favor de uma reforma na medicina da Atenas histórica. Reforma de um projeto de medicina decadente, que ele chama de pedagogia da doença, pois gera cidadãos hipocondríacos, que usam a saúde como álibi para se esquivarem das obrigações políticas.

PALAVRAS-CHAVE: Platão, medicina hipocrática, saúde, filosofia, política. 


\begin{abstract}
The thread of this work revolves around the relationship between Platonic philosophy and medicine. In his "birth", the medicine has different dialog interfaces with philosophy also "spring". Several commentators have dedicated themselves to unravel the pathways of this relationship. Talk about Plato's relationship with medicine requires that this dialogue be framed in the polis of the environment of the fifth and fourth centuries BCE, always in dialogue with the Hippocratic writings. Unlike Galen and the Platonic tradition, we follow the hypothesis that Plato would polemic against the medicine of his time. To demonstrate this, we turn to criticism of Plato medicine "Hippocrates" and their social consequences in classical Greece. The hypothesis of this work is that Plato would have been a connoisseur of medical theories of his time, and attacking new therapeutic currents springs, stands in favor of a reform in medicine historic Athens. Reform a decadent medicine project, which he calls the "pedagogy of the disease", because it generates hypochondriacs citizens, using health as an alibi to shirk the political obligations.
\end{abstract}

KEYWORDS: Plato, Hippocratic Medicine, Health, Philosophy, Politics. 


\section{SUMÁRIO}

INTRODUÇÃO

CAP. 1. PROBLEMAS NAS ABORDAGENS DE PLATÃO E A MEDICINA

1. PLATÃo $E$ A MEDICINA NOS DEBATES ANTIGOS E CONTEMPORÂNEOS.

1.1. Gênese do problema: Platão e a medicina na Antiguidade.

1.1.1. A medicina na Academia antiga.

1.1.2. O médico das almas e do corpo no medioplatonismo.

18

1.1.3. Galeno: Platão, o imitador de Hipócrates.

1.1.4. A medicina em Platão depois de Galeno.

1.2. Debates contemporâneos.

1.2.1. A teoria das três correntes de medicina: hipocrática, itálica, cnidiana.

1.2.2. A questão hipocrática e Platão: onde está o verdadeiro Hipócrates?

1.2.3. Interpretação de Platão como leitor de Hipócrates.

1.2.4. Platão como cientista natural.

2.1. Platão e a medicina na leitura "unitarista". 
2.2. Platão e a medicina na leitura "evolucionista".

2.2.1. Pressupostos "evolucionistas" na abordagem dos diálogos.

2.2.3. A medicina segundo o "evolucionismo": craft-analogy $e$ descontinuidades.

2.3. A medicina em Platão no contexto político.

2.3.2. Leitura moralizante da República e o debate sobre o vegetarianismo e saúde.

2.3.3. A leitura totalitária da República III: A crítica de Popper ao historicismo e engenharia social de Platão. 
1.2. Medicina como analogon.

1.2.1. O desenvolvimento do analogon no Livro II.

2. CRÍTICA À MEDICINA: NOVAS DOENÇAS, NOVAS TERAPIAS, NOVOS DOENTES.

2.1. Novas doenças: mais tribunais e mais médicos.

2.1.1. Analogon: multiplicação de tribunais.

2.1.2. Multiplicação de clínicas e novas doenças.

2.1.3 Crítica ao progresso a qualquer custo.

2.2. Novas terapias: medicina de Asclépio versus Heródico.

2.2.1. As práticas terapêuticas na Ilíada: o tratamento de Macáon e de 77 Eurípilo.

2.2.2. Novas terapias: Heródico e a "pedagogia da doença".

2.3. Novos doentes: os dois grupos. 
1.1. O conceito de justiça e a alma tripartida.

1.2. O conceito de ações justas e a saúde.

2. O CONCEITO DE MEDICINA.

2.1. O Princípio da Oposição e o Princípio da Qualificação.

2.2. Medicina: ciência da saúde e da doença.

3. O CONCEITO DE MÉDICO.

3.1. Os médicos gregos: busca pela autoridade.

3.2. Os agathoi iatroi e a reforma do sistema de saúde.

3.2.1. Ataque ao mito de Asclépio: filho de um deus não é ávido de ganho sórdido.

3.2.2. Os bons médicos e sua formação.

3.2.3. Os bons médicos e cura do corpo pela alma.

CONCLUSÃO

APÊNDICE 1

APÊNDICE 2

REFÊNCIAS BIBLIOGRÁFICAS 


\section{INTRODUÇÃO}

Em praticamente todos os diálogos platônicos há uma referência à saúde, medicina, tratamento, cura ou médico. Apesar disso muito pouco se tem escrito sobre a relação entre Platão e a medicina (VEGETTI, 1995, p.vii). Talvez porque estudar esta relação seja uma tarefa especialmente desafiadora. Existem, de fato, algumas dificuldades neste estudo que podem não ser percebidas antes de se iniciar tal investigação.

A primeira dificuldade é o fato de Platão não escrever um diálogo específico sobre a medicina. Temas médicos permeiam todo o Corpus de diálogos, se encontrando, confrontando e ilustrando vários temas, com propósitos diversos. Eles se situam (VEGETTI, 1995, p.vii) no plano metafórico, analógico, epistemológico, crítico e médico-biológico tout court $^{1}$. É difícil achar um fio condutor que ligue todas as referências à medicina nos diálogos, por isso é necessário a sua contextualização. A noção de saúde e doença, por exemplo, é utilizada para explicitar (LLOYD, 2003, p.142) alguns aspectos nucleares do pensamento platônico como sua psicologia e sua teoria da justiça. Porém nem sempre estas "teorias" platônicas (se é que exista uma) possuem consenso entre os estudiosos, logo as analogias evocadas para explicitá-los ficam à mercê de suas interpretações.

A segunda dificuldade reside nas características do diálogo: Platão nunca fala em primeira pessoa. Ele usa Sócrates, Teeteto, o Estrangeiro de Eléia, Diotima, o Ateniense, Timeu, etc. Neste contexto, alusões preciosas sobre a medicina do seu tempo aparecem ora na boca de Sócrates, ora na boca de seus interlocutores; muitas vezes, a conclusão deste elenchos é uma aporia formal, tornando ainda mais difícil compreender a valência teórica das aproximações com a medicina.

Por fim, a terceira dificuldade está no tratamento das fontes. Platão não cita os tratados hipocráticos como ele cita Homero, antes ele dialoga com as ideias da medicina utilizando-as para seus próprios propósitos (KUCHRASKI, 1939, p.301ss). Por isso, não se pode dizer que Platão leu determinado livro do Corpus hippocraticum, ou que determinado diálogo é uma reação direta a estas obras.

\footnotetext{
${ }^{1}$ Como é o caso do Timeu.
} 
Acrescenta-se que, com os livros e fragmentos que chegaram até nossos dias, dificilmente podemos identificar algum tratado que tenha derivado diretamente da pena de Hipócrates. Ao falar sobre Hipócrates ou médicos hipocráticos, somos necessariamente obrigados a entender um evento cultural e "antropológico", um campo de pensamento produzido no âmbito do saber médico, que surgiu no século $\mathrm{V}$ aEN.

A tradição, através de Galeno, nos legou uma ideia que Platão estaria adaptando os conceitos e o vocabulário da medicina hipocrática para sua filosofia. Platão pareceria ser de fato um grande admirador de Hipócrates, como comprovaria o elogio que faz de seu método no Fedro.

Todavia, este entendimento tem sido questionado, especialmente nas últimas décadas. Platão parece, de fato, estar mais interessado em polemizar e colocar um limite na medicina. Esta ideia nos surgiu ao ler a crítica à medicina no Livro III da República. Levin (2014, p.115) admira que a um texto tão rico para o debate não foi dada a devida atenção por parte dos estudiosos. A passagem não é uma simples digressão; ela faz parte de uma série de críticas à paideia da Atenas histórica. O texto nos levou a levantar a hipótese que Platão estaria fazendo, pela verdade, uma crítica à medicina hipocrática e não, como se considera em geral, buscando nela um paradigma para suas ideias políticas.

A metáfora entre medicina e política não é uma inovação de Platão. Ela aparece já antes de 430 aEN, mas se torna frequente durante e após a peste que assolou Atenas durante a Guerra do Peloponeso (BOYASK, 2007, p.1-7). Não faltaram menções à saúde e doença nas tragédias e nas comédias. Tucídides (6. 14) utiliza a expressão "médico da cidade", em um contexto de voto e discussão sobre o bom cidadão.

Se Platão polemiza contra a Weltanshauung de sua época, da qual os sofistas, os poetas, os trágicos, Tucídides e os políticos são seus representantes; e se eles se valeram do modelo grego de medicina para esclarecer ou desenvolver suas teorias políticas, então Platão parece tentar refutar este modelo de medicina também. O uso platônico destas metáforas e analogias é meticulosamente articulado. Não parece que ele esteja usando o mesmo conceito de medicina que os gregos frequentemente imaginavam. Isso pode ser confirmado no Livro I da República, onde Trasímaco evoca a figura do médico. Sócrates retruca apelando para o bom médico. 
Dizer que Platão está polemizando contra a medicina hipocrática pode incorrer no risco de sermos mal interpretados, ao pensar que o alvo específico de Platão foi Hipócrates e seus discípulos. Além disso, existe o espinhoso e árduo problema da datação. Não há como precisar o ano específico em que os tratados hipocráticos foram escritos. Alguns escritos foram considerados do século $\mathrm{V}$ aEN, mas outros foram, sem sombra de dúvidas, redigidos durante o período romano. Para isso, apresentamos no Apêndice 1, um quadro das obras hipocráticas datadas dos séculos IV e V aEN. A datação apresentada segue os mais recentes estudos de Schiefsky (2005), Jouanna (1992) e Garcia Gual (2008); e tenta ser o mais geral possível limitando-se a dizer o período do século em que provavelmente a obra foi "publicada".

Estudar mais precisamente a crítica de Platão à medicina "hipocrática" e às suas respectivas consequências sociais é importante para lançar luz às margens dos diálogos platônicos. Acreditamos que Platão deva ser interpretado, obviamente pelo seu texto, mas também pelas diversas alusões que ele faz aos seus contemporâneos. Por isso, pensamos que o estudo platônico deve andar em conjunto com a filologia, a história, a medicina, a matemática; porém tomando sempre o cuidado de não se reduzir a estes. Seguindo este pressuposto, nos valemos de diversas e mais atuais fontes de pesquisa: historiadores, filólogos, historiadores da medicina, intérpretes de Platão, etc.

A necessária economia desta dissertação não nos permite ir muito além, visitando todas as passagens do Corpus platônico, por isso nos limitamos a investigar os quatro primeiros livros da República. Esta escolha se deu por causa da centralidade da República nas discussões sobre a política em Platão. Da mesma forma, os primeiros livros apresentam uma abordagem filosófica da política na qual a medicina exerce um papel especialmente importante. Para isso, dividimos a presente dissertação em três capítulos.

No primeiro capítulo, identificaremos a gênese da relação entre Platão e os hipocráticos na Antiguidade e seu desenvolver nos nossos dias. O frequente uso socrático das metáforas médicas unidas com o desejo de uma salvação deu origem à imagem helenística de um "Platão médico das almas". Com Galeno, esta metáfora toma um rumo diferente: Platão é discípulo de Hipócrates. Platão é visto como um médico, que escreveu sobre medicina. Sob formatos diferentes, estas ideias persistem até a atualidade. Veremos também alguns pontos de intersecção entre as interpretações do Platão político com a temática da medicina. 
No segundo capítulo analisaremos o uso da medicina na craft-analogy, iniciando pelo Livro I de República. No desenrolar dos Livros II e III, veremos como Platão se vale da medicina no analogon entre a cidade e a alma. Em seguida, caminharemos para considerar os pormenores da crítica ao sistema médico da Atenas dos séculos V e IV aEN.

No terceiro capítulo, iremos tentar responder à pergunta sobre quem seria o bom médico para Platão. Para responder de uma maneira mais precisa possível, buscaremos no Livro IV os conceitos de saúde e medicina. Neste momento, visitaremos os conceitos de saúde e de medicina que existem nos tratados médicos unanimemente datados dos séculos $\mathrm{V}$ e IV aEN. Em seguida, confrontaremos os resultados com a abordagem platônica à medicina.

Como resultado da pesquisa, constatamos que, na República, Platão está atacando as novas terapias da medicina que lhe era contemporânea e propondo uma reforma no seu meio. Ele parece polemizar com a medicina da mesma forma que polemizava com os sofistas, ou seja, apropriando-se de seus conceitos para usá-los contra eles. Para que se veja com clareza, é necessário a desconstrução de uma imagem de Platão, a imagem que Galeno construiu: Platão, o grande imitador de Hipócrates.

Por fim, para as obras e autores da Antiguidade nos valemos das abreviaturas de Liddell-Scott-Jones. Utilizamos as normas do Archai (2014, p.193) para a transliteração dos caracteres gregos. 


\section{CAPÍTULO PRIMEIRO}

\section{PROBLEMAS NAS ABORDAGENS DE PLATÃo E A MEDICINA.}

Parte da imagem que temos de Platão é um constructo que se desenvolveu desde a Antiguidade tardia, dentro e fora do que se chama hoje de platonismo. A relação de Platão com a medicina de seu tempo está inserida nesta invenção que se prolongou até hoje se mesclando com as diversas interpretações de Platão.

Além disso, aquele que tenta escrever sobre Platão e a medicina logo verá o porquê tais escritos não são tão comuns. Não se pode fazer jus ao tema sem uma mínima discussão sobre as noções platônicas de alma, política, techne, etc. Nem se pode falar sobre esta questão sem tocar nos debates atuais sobre a cronologia dos diálogos, sobre as hipóteses "unitaristas" e "evolucionistas" do pensamento de Platão e sobre a imagem de um Platão político.

\section{PLATÃo E A MEDICINA NOS DEBATES ANTIGOS E CONTEMPORÂNEOS.}

A relação entre Platão e a medicina de seu tempo foi notada desde a antiguidade tardia. De um lado, alguns filósofos de influência estóica interpretavam a filosofia como uma medicina da alma, capaz de curar os medos e as tristezas humanas. Referiram a Sócrates e Platão como sendo médicos das almas. De outro lado, Galeno tentou conciliar os diálogos de Platão com os escritos de Hipócrates. O médico de Pérgamo escreveu uma obra extensa conhecida como De Placitis ou As Doutrinas de Hipócrates e Platão, além de um comentário ao Timeu, do qual restaram apenas fragmentos. 
Na modernidade os classicistas buscaram o verdadeiro Hipócrates ${ }^{2}$. Este debate rendeu duas frentes. Na primeira frente, tentou-se separar a escola de Cós, racional, da escola de Cnido, empírica. Na segunda frente, tentou-se descobrir qual era o escrito que Platão citava no Fedro, para descobrir o escrito da pena de Hipócrates. Surgia o debate chamado Questão Hipocrática. No meio deste debate, muitos classicistas e pesquisadores do platonismo fizeram ligações entre o Corpus hippocraticum e Platão. Estas ligações se deram através da análise de vocábulos e analogias que lhes eram comuns.

\subsection{Gênese do problema: Platão e a medicina na Antiguidade.}

Platão morreu no primeiro ano da centésima oitava Olimpíada, no décimo terceiro reinado de Felipe da Macedônia, 347 aEN, e foi enterrado na Academia. Existem poucas informações confiáveis sobre sua vida ${ }^{3}$. Em seus escritos, Platão se manteve fora de cena ${ }^{4}$. Ele aparece somente duas vezes nos diálogos, uma no julgamento de Sócrates (Ap. 34a) e outra para explicar sua ausência nas últimas horas do seu "mestre" (Phd. 59b).

Alguns amigos e discípulos escreveram sobre ele, entre eles estão Espeusipo, Xenócrates, Filipo de Opunte, Hermodoro e Erasto. Porém, suas obras foram mais elogios que biografias e mesclaram lendas e fatos (GUTHRIE, 1990, p. 19-20). Seu sobrinho, Espeusipo, atribuiu-lhe uma origem divina, o deus Apolo (DL, 3.2). Todos estes primeiros escritos se perderam e a Vita mais antiga que chegou até nós foi escrita por Apuleio ${ }^{5}$ no séc.II d.E.N. ${ }^{6}$ Ele escreveu sobre Platão em De Platone et eius dogmate apoiando-se em relatos legendários e anedóticos provindos da Academia antiga (1. 1-4).

\footnotetext{
${ }^{2}$ Este debate se consolideou com Littrè (1839-1861), mas antes dele inúmeros clacissistas levantaram diversas hipóteses, para uma discussão pormenorizada ver Lonie (1978, p.42-75; 1978, p.77-92).

${ }^{3}$ Para a vida de Platão cf. Nails (2011, p.17-27); Guthrie (1990, p. 19-41); Vegetti (2003, p.9-22); Crombie (1962, p.13-21).

${ }^{4}$ Se a Carta VII é autêntica, pode-se declarar que estamos diante de um documento autobiográfico. Contudo existem muitas controvérsias sobre sua autenticidade. Para esta discussão ver: Brisson (2003, p.23-34); Irwin (2009, p.7-43); Guthrie (1990, p.16-34); Vegetti (2003, p.9-21). Vegetti nota que a maioria dos que levantam argumentos contra ou a favor da autenticidade da Carta VII, fundamentam-se no pressuposto de um Platão político ou despolitizado. Nós aceitamos a Carta como, se não autêntica, um testemunho verossímil da vida de Platão.

${ }^{5}$ Albert (2011, p.47-54) defende a tese que Apuleio, apesar de carregar o título de philosophus platonicus, não era um platonista em sentido estrito, pois mesclava as teorias de Platão com elementos aristotélicos, estóicos e herméticos. Porém esta é uma posição controversa. O próprio Albert o considera ao lado dos medioplatônicos.

${ }^{6}$ Há também uma Vita anônima e outra escrita por Olimpiodoro no século VI da nossa era.
} 
Não muito posterior está o livro de Diógenes Laércio, Vida e doutrina dos filósofos ilustres. Este último carece de critérios críticos aceitos na atualidade, mas é sem dúvida a mais valiosa biografia por causa de sua menção de fontes antigas, entre os quais estão contemporâneos de Platão e Aristóteles.

A maioria dos biógrafos da antiguidade segue o padrão de vida feito na medida do bibliotecário alexandrino Apolodoro ${ }^{7}$, dividindo as vidas dos antigos em quatro períodos de vinte anos (NAILS, 2011, p.17). Segundo este esquema, Platão teria nascido em 427 aEN, encontrado com Sócrates aos 20 anos, fundado a Academia aos 40, viajado para Sicília aos 60 e vindo a falecer aos $80^{8}$.

\subsubsection{A medicina na Academia antiga.}

Em algum momento de sua vida Platão fundou a Academia nos jardins públicos de Atenas dedicado ao heroi Academo (DL, 3. 7). Todavia parece pouco provável que a "escola" de Platão gozasse de um reconhecimento oficial por parte da polis ateniense (VEGETTI, 2003, p.204). Existem várias hipóteses sobre a Academia afirmando que era: uma sociedade "festiva" onde se realizavam banquetes, uma seita religiosa de salvação espiritual, um seminário universitário de pesquisa científica, uma comunidade de formação política, uma nova forma de sociedade secreta que aspirava a conquista do poder (VEGETTI, 2003, p.201). Talvez exista um pouco de verdade em cada uma destas suposições.

A Academia era uma comunidade de intelectuais reunidos em torno de Platão, que autossustentavam e buscavam vários interesses. É provável que não existisse um corpo docente e nem alunos que assistiam uma série de cursos para qualificá-los a exercer algum cargo, ofício ou posição na polis (MUELLER, 2013, p.201). Testemunhos antigos atestam uma forte tendência para os estudos de geometria, astronomia e matemática dentro da Academia $^{9}$. Mas um fragmento do comediante Epicrates ${ }^{10}$, contemporâneo de Platão, sugere que na Academia eram realizados estudos de outras disciplinas.

\footnotetext{
${ }^{7}$ Para maiores detalhes sobre o gênero biografia na antiguidade cf. Untersteiner (1980, p.223-48). Untersteiner sustenta que as biografias tardias se fundem com os diadochai e com os doxai do filósofo.

${ }^{8}$ É necessário ter em mente que nem todos escreveram elogiando Platão. Cf. Brisson (2003, p.35-54); Chroust (1962, p.98-118); Guthrie (1990, p.20-23). Durante a antiguidade houve um anti-platonismo que tentava desvalorizar uma doutrina em detrimento de outra com a acusação de plágio. Chroust afirma que nenhum autor da antiguidade foi tão atacado como Platão.

${ }^{9}$ Cf. Vegetti (2003, p.208-13); Mueller (2013, p.201-9). Ver também Isoc. 15. 354.
} 
Neste fragmento alguém pergunta o que Platão, Espeusipo e Menedemo estão fazendo agora, que tipo de argumento eles estão investigando. Outra pessoa responde que, no festival panatenaico, ele viu jovens alegres nos ginásios da Academia fazendo distinções e definições sobre a natureza, a vida dos animais, a natureza das árvores e o gênero dos vegetais. Entre outras coisas, diz o narrador, estavam discutindo o gênero da abóbora. Refletiam se a abóbora era um legume, uma gramínea ou uma árvore. Então, um médico siciliano, que ouvia essas coisas, bufou para aqueles tolos. Platão estava presente. Tranquilamente mandou que eles começassem de novo a definir o gênero da abobora e eles continuaram.

Esta representação cômica, que faz da figura de Platão um supervisor uma classificação biológica dentro da Academia, parece não ser compatível com a proposta educacional da República. A esta objeção Vegetti (2003, p.206) e Mueller (2013, p.204) respondem que a Academia deve ser concebida como um ambiente em que o texto da República foi escrito, elaborado e discutido, e não como um local onde seu programa educativo deveria ser aplicado ${ }^{11}$. Cherniss (1962, p.62-3) defende que esta paródia de Epícrates é uma evidência do método de divisão e classificação praticado pelos membros da Academia. Porém isto não elimina a possibilidade de existirem discussões internas sobre as teorias físicas e fisiológicas quando Platão escreveu o Timeu.

A comédia nada fala se o médico siciliano pertencia ou não à Academia. Nada podemos inferir da imagem de um médico, a não ser que ele desdenhou da discussão através de um bufão e considerando-a frívola e tola. Porém existem alguns "médicos" e filósofos da natureza que são relacionados com a Academia na antiguidade: Timeu de Locros ${ }^{12}$, Filistíon de Locros $^{13}$ e Eudoxo de Cnido ${ }^{14}$. Mesmo que alguns sejam considerados míticos, existem fortes indícios que Platão tenha debatido também sobre a medicina os quais serão demonstrados ao longo desta dissertação.

Após a morte de Platão começaram muitas controvérsias dentro da Academia (CHERNISS, 1962, p.74) sobre a sua teoria da alma, sobre as Formas e sobre a interpretação do Timeu. Isto parece comprovar que não havia uma doutrina única na Academia (GUTHRIE,

\footnotetext{
${ }^{10}$ Cf. Epícrates (2007, p.502-3).

${ }^{11}$ Contra esta ideia ver Guthrie (1990, p.463).

${ }^{12}$ Gomperz (2011, p.226ss) acredita na existência de um Timeu histórico, seguindo Cícero (R.I, X). Lloyd (2009, p.157) defende que Timeu é o próprio Platão. Para a questão do Timeu históricover o comentário de Lopes (2011, p.20-23) na introdução do diálogo Timeu.

${ }^{13} \mathrm{Cf}$. Pl. Ep. II.314d-e

${ }^{14}$ Cf. DL, 8. 86.
} 
p.463), nem uma ortodoxia, senão uma ampla variedade de teorias no seu interior. A primeira codificação feita da filosofia de Platão foi executada por Espeusipo e Xenócrates. Parece que eles tentaram "matematizar" a filosofia e desenvolver uma teoria astral (VEGETTI, 2003, p.216). Todavia, antes destas teorias desenvolverem e tomarem forma de um platonismo doutrinal, a Academia sofreu uma virada dramática. Sob a liderança de Arcesilau se desenvolveu o ceticismo, ou seja, a crítica a toda pretensão de verdade dos sistemas filosóficos dogmáticos, tanto estóicos como aristotélicos. Nos próximos dois séculos, os filósofos acadêmicos seriam vistos como "os que suspendem o julgamento sobre tudo" (LONG, 2011, p.390).

\subsubsection{O médico das almas e do corpo no medioplatonismo.}

No século I aEN, o ceticismo perdeu a força e a maioria dos platônicos retornou a um estudo dos diálogos concentrado na identificação de doutrinas, dando origem ao que se chama de platonismo ${ }^{15}$ médio e neoplatonismo (LONG, 2011, p.391). A escolha foi radicalmente oposta à tendência cética. As diversas "seitas" nascentes se mostravam rivais, o ambiente cultural da sociedade imperial romana aspirava à salvação espiritual, buscando respostas místicas e religiosas. Então, o platonismo se voltou para a construção de um "sistema" metafísico-teológico.

Neste período Cícero (106 - $43 \mathrm{aEN),} \mathrm{grande} \mathrm{orador} \mathrm{e} \mathrm{estadista} \mathrm{romano,} \mathrm{que} \mathrm{não} \mathrm{era}$ estóico, embora tenha estudado intensamente o estoicismo e conheceu pessoalmente Posidônio (BRENNAN, 2010, p.27), escreve as Tusculanas. Nesta obra, Cícero define a filosofia como medicina da alma (Tusc. 3. 1). Segundo ele, existe uma medicina da alma, ou seja, a filosofia, que não deve ser buscada fora de nós, como a medicina do corpo. Esta medicina da alma deve ser capaz de ajudar o homem a curar a si mesmo. Se o homem for buscar um médico das almas, exorta Cícero, que busque um filósofo antigo sério (Tusc. 3. 19). Ele pergunta retoricamente se um amigo for afligido por tristeza lhe daríamos um esturjão em lugar de um tratado socrático ou lhe recomendaria que ouvisse um órgão hidráulico no lugar das palavras de Platão? Certamente não.

\footnotetext{
${ }^{15}$ Vegetti (2003, p.216) nota que não se pode falar de um platonismo ou de uma tradição platônica. Há diversos tipos de platonismos: de origem cética, de inspiração político e utópico, o platonismo espiritual, o que é baseado em uma cosmo-teologia, de origem dialético-metafísica.
} 
Assim como os médicos expressam em que a causa da doença deve ser encontrada, Cícero sustenta que a causa da doença da alma são as opiniões (Tusc. 3. 25). A causa dos sofrimentos deve ser buscada em uma opinião sobre a proximidade ou a distância temporal dos eventos dolorosos. E a cura para eles deve ser a meditação cotidiana (Tusc. 3. 30).

Segundo Dodds (2002, p.265), a frequente metáfora médica utilizada por Sócrates nos escritos de Platão foi decisiva para que a maioria das escolas filosóficas relacionasse a figura do filósofo com um médico de almas, parecido com um psicoterapeuta da atualidade. Epicteto $^{16}$ (c. 55 - 135 d.C), por exemplo, defendia o caráter prático da moral comparando-a sempre com a medicina e a música. Na maioria das vezes, ele apontava Sócrates como um exemplo do tipo de vida no qual seus discípulos deveriam seguir (RYLE, 1894, p.125). Nas suas Dissertações (3. 23.30) comparou a escola do filósofo com um hospital. Marco Aurélio (121 - 180 d.C.) vai mais além. Nas Meditações (3. 4), ele escreve que o filósofo não é somente o que cura almas como um "psicoterapeuta", mas ele "é um sacerdote, um ministro dos deuses, servidor daquele nume estabelecido em seu âmago". Quase a mesma coisa é dita por um filósofo cristão do segundo século, simpatizante do platonismo, Justino de Roma. No seu Diálogo com Trifão (2.6), ele relata que o objetivo do platonismo é "contemplar o próprio Deus." 17

Ao lado desta imagem salvífica e "psicoterapêutica" do médico das almas, aparece outra imagem, mais voltada para a física, dentro do platonismo que se estendeu até os escritos de Galeno. Esta imagem não é oposta à primeira. Elas coexistiram juntas no medioplatonismo (BRISSON, 2011, p.226-7), onde o Timeu é estudado a partir de um prisma da filosofia natural e ao mesmo tempo Platão era interpretado através de um espírito teosófico, apelando para a magia, astronomia e demonologia. Um exemplo disto é a obra Platone et eius dogmatede Apuleio (125 - 170 d.C.). O primeiro livro relata a vida de Platão de forma mítica e fantástica, em seguida trata de temas da Física, da filosofia natural e da saúde. Após relatar o ensinamento de Platão sobre a composição do corpo, ele fala que a saúde é o equilíbrio do seco e úmido, quente e frio (1.8). Por fim, ele explana as doutrinas platônicas expressando

\footnotetext{
${ }^{16}$ Foi aluno de Musônio Rufo, foi um pensador estóico que não deixou nenhuma obra. O registro de suas conversas foi documentado por um de seus discípulos, Ário (BRENNAN, 2010, p.22-24).

${ }^{17}$ Justino de Roma ou Justino, o mártir, nasceu aproximadamente no ano 100 da nossa era e foi decapitado em 165 acusado por Crescente, um filósofo cínico. Ele relaciona Platão com Moisés na Apologia (I, 59-60). Segundo ele Platão era discípulo de Moisés, pois este era anterior àquele.
} 
que a alma que a razão governa possui saúde, consequentemente a doença da alma é a imperícia e a loucura (1.9-18) ${ }^{18}$.

\subsubsection{Galeno: Platão, o imitador de Hipócrates.}

Porém, foi Galeno (130 - 210 d.C.) quem mais contribuiu para formar a ideia que temos sobre Platão e a medicina. Galeno pode ser chamado platônico porque o termo "platonismo" é amplo (DE LACY, 1972, p.27), mas na verdade ele se avizinha mais de Aristóteles que de Platão (VEGETTI, 2013, p. 18). Frede (1987, p.279-98) o considera como um eclético, no máximo um platonista eclético, devido às seguintes razões:

(a) ele não simpatizava com o epicurismo, como seus contemporâneos;

(b) dentre todos os filósofos clássicos ele escolhe Platão simbolizar o que Hipócrates era para os médicos;

(c) ele foi influenciado pelo estoicismo ${ }^{19}$;

(d) ele recebe influências de Aristóteles e dos peripatéticos.

Então porque dizer que Galeno era platônico? Segundo Singer (1991, p.54-5), não se comprometeu com o platonismo, mas tinha alguns propósitos em aproximar dele:

(a) na época os filósofos eram membros mais respeitáveis da sociedade;

(b) o rigor das disciplinas matemáticas era um traço platônico que era proveitoso para alcançar autoridade e desacreditar seus oponentes;

(c) a concepção platônica de uma pequena elite possuidora de conhecimento permitiu a Galeno estabelecer uma estreita conexão entre conhecimento e virtude.

\footnotetext{
${ }^{18}$ Para Apuleio a imperícia é a pretensão orgulhosa demonstrada, por exemplo, quando um ignorante quer ensinar. A loucura ou estultícia é o resultado de maus hábitos e de uma vida desregrada.

${ }^{19}$ Segundo Brennan (2010, p.31), Galeno considerava os estóicos redundantes quando concordavam com as opiniões de Hipócrates e Platão; e quando discordavam eram culpáveis.
} 
Além disso, poderíamos acrescentar que Galeno relata ter estudado com Albino em Esmirna (Libr.Prop. 2). Ele deu dois de seus livros a um amigo que era platônico (Libr.Prop. 1) e incluía na maioria das vezes os platônicos entre os quais ele concordava.

Galeno também foi um grande seguidor de Hipócrates. Segundo ele ${ }^{20}$, o médico deve conhecer a filosofia segundo a tripartição tradicional estóica em lógica, física e ética. A concepção do médico coincide em parte com a figura do iatrosophistes ou iatrophilosophos ${ }^{21}$ típica do período da Segunda Sofística. A sociedade da épocavia com entusiasmo este tipo de médico por causa do saber que possuíam, pois eles poderiam satisfazer suas necessidades "salvífico-milagrosas" e a "racional".

O Hipócrates de Galeno não é o médico que Plínio descreve (HN 29.4), ou seja, um homem que fugiu para Larissa, acusado de incendiar o templo de Asclépio de Cós, depois de ter utilizado suas inscrições medicais. Galeno projeta em seu Hipócrates a imagem de um médico virtuoso para polemizar contra os médicos da sua época que praticavam rapinagem (LLOYD, 1991, p.415-6). Hipócrates era um médico dos pobres, que deixou Pólibo cuidando de seus concidadãos em Cós e percorria outras cidades com o objetivo enriquecer sua experiência (Med.Phil. 3).Para construir o paradigma de bom médico, Galeno utiliza também uma combinação entre Hipócrates e Platão (TEMKIN, 1953, p.224). Hipócrates e Platão estão juntos com Homero e Sócrates no "chorus" mais próximos do deus Hermes, eles são seus assistentes e representantes, aos quais, Galeno venera de modo semelhante aos deuses (Protr. 4), pois eles são divinos ${ }^{22}$.

Hipócrates é o melhor de todos os médicos ${ }^{23}$ porque:

(a) seu método científico é elogiado por Platão no Fedro;

(b) ele expressa princípios morais, pois não busca seus próprios interesses e se dedica ao máximo para sua arte;

\footnotetext{
${ }^{20}$ Med. Phil., 3.

${ }^{21}$ Med. Phil., 4.

${ }^{22}$ Sobre Hipócrates como theios, ver Que as faculdades da alma seguem os temperamentos do corpo, 7. Sobre o “divino Platão", ver Utilidades das partes, XVI,1. Para a imagem de Hipócrates como homem divino, nem como deus, nem como mágico, ver Temkin, (1995, p.71-75).

${ }^{23}$ De plac,III,4. Cf. Lloyd (1991, p.403-7)
} 
(c) sua medicina é baseada em uma fisiologia, patologia e "psicologia" correta;

(d) existe uma superioridade do seu prognóstico e das suas técnicas terapêuticas.

No entanto, Platão não era tão grandioso, pois (DE LACY, 1972, p.33-9) seu conhecimento de medicina era mais limitado que o de Hipócrates. E também, Hipócrates era anterior a Platão, sendo sua maior fonte doutrinária. Ele mostra no De usu partium, (1.8) que "Platão era um admirador de Hipócrates [...] e tomou dele as principais doutrinas" 24 . Inclusive a teoria da tripartição da alma e sua relação com as diferentes partes do corpo são de Hipócrates. Mesmo que ele não tenha dito isto claramente, Galeno exorta que o Corpus hippocraticum deve ser interpretado (LLOYD, 1991, p.407-16).

A contribuição de Galeno foi relacionar pela primeira vez, na história do platonismo ${ }^{25}$ e da medicina, a imagem de Hipócrates e Platão (e consequentemente seus escritos) através de uma engenhosa capacidade argumentativa.

\subsubsection{A medicina em Platão depois de Galeno.}

Outra imagem de Platão irá aparecer em Diógenes Laércio na forma de epitáfios ${ }^{26}$ :

Se Foibos não tivesse dado a vida a Platão na Hélade, como poderia ter curado com as letras as almas dos homens? Seu filho Asclépios é o médico do corpo, da mesma forma que o da alma imortal é Platão.

E outro sobre as circunstâncias de sua morte:

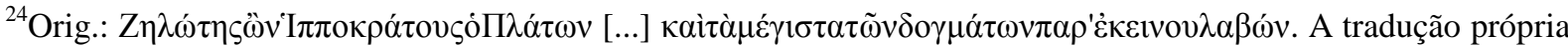
seguindo Vegetti (1978,p.327) que traduz todo o trecho da seguinte forma: "Qual è dunque Il motivo del fatto che Platon, pur essendo ammiratore di Ippocrate quando nessum altro e pura vendo preso da lui le più importanti delle sue teorie, si e pronunciato così poço sull'utilita delle unghie?" A tradução de Charles Daremberg (1994,p. 12) diz: Comment se fait-il que Platon, imitateur d'Hippocrate, s'il em fut jamais, et qui a emprunté sés plus grands dogmes, ait traité des ongles avec si peu de soin? A tradução de Mercedes Lopez Salva (2010,p. 98) diz: “¿Por qué Platón, que emuló a Hipocrates, si es que alguien lo ha emulado, y que tomó la mayoria delas doctrinas de él, apenas dijo nada sobre la funcion de las uñas?"

${ }^{25}$ Pelo menos nos escritos que chegaram até nós.

${ }^{26}$ Notopoulos (1942, p.272-293) acredita que estes epigramas não são autênticos, mas uma criação literária, pois nesta época havia confusão entre os epigramas (epitáfios) e a literatura epigramática.
} 
Foibos criou para os mortais Asclépios e Platão, um para salvar o corpo, o outro para salvar a alma. De um banquete nupcial Platão partiu para a cidade que fundou e construiu no solo de Zeus. (DL, 3. $45)^{27}$

Certamente estes epitáfios faziam parte de uma literatura epigramática, e eles apresentam um Platão ligado ao deus da medicina Asclépio e não à Hipócrates. Platão é o que cura (ekesato) as almas dos homens (psychas anthropon) através das letras (grammasin) e Asclépio cura (ietrike) os corpos humanos. Os epigramas recolhidos por Diógenes Laércio e também registrados na Antologia Palatina ${ }^{28}$ fazem parte de uma tradição místico-salvífica que descrevemos acima. Na segunda parte do Livro III, Diógenes Laércio passa a falar de um modo mais dogmático. Ele relata que Platão dividia a medicina em cinco partes (DL, 3. 85): a farmacêutica (pharmakeutike), a cirúrgica (cheirougike), a dietética (diaitetike), a diagnóstica (nosognomonike) e o pronto-socorro (boethetike).

A formação da imagem platônica relacionada com a medicina atravessa a Idade Média e chega até mesmo na tradição árabe. Segundo Fernades (2013, p.143-8), Abū al-Faraj Muḥammad ibn Isḥāq ibn al-Nadīm considerava Platão como médico, que aprendera diretamente de Hipócrates. Abū Dāwūd Sulaymān ibn Ḥasan ibn Juljul al-Andalŭsī no Livro das gerações de doutores e sábios (kițāb Tabaqāt al-Ațibbā' wa 'l-Humakā') fornece a mesma informação, ou seja, Platão era médico.

Esta imagem de Platão, ora médico das almas, ora preocupado com as questões do corpo, chega até a modernidade quase inalterada. Porém, na busca de um verdadeiro Hipócrates, pai da medicina racional, os filólogos irão outra vez recorrer a Platão para buscar as respostas. Quem era o Hipócrates de Platão? Qual era a sua doutrina descrita no Fedro? E qual obra do Corpus hippocraticum que mais se aproxima com o testemunho platônico? Tais indagações deram origem à Questão Hipocrática.

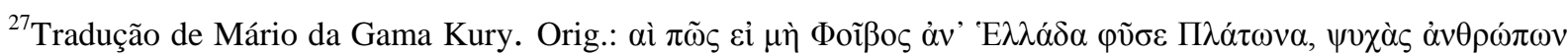

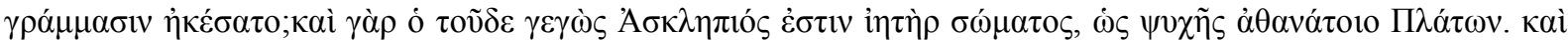

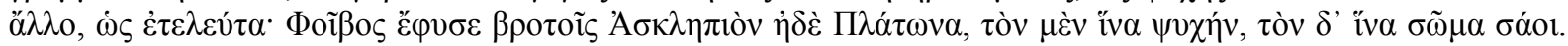

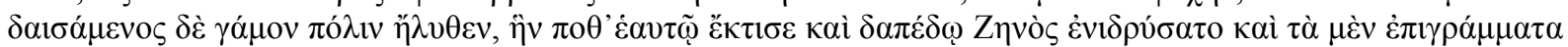
$\tau \alpha \tilde{\tau} \tau$.

${ }^{28}$ A.P. VII, 108, 109.
} 


\subsection{Debates contemporâneos.}

Os ataques de Francis Bacon aos gregos antigos, declarando que eles não possuíam o hábito da experimentação, suscitaram debates na modernidade sobre a ciência antiga e moderna (CORNFORD, 1952, p.17-26). Mas no que concerne à medicina antiga, pode-se dizer que ela era racional ou empírica? Para responder isso os classicistas voltaram-se, então, para Galeno. No Método do Tratamento (1. 1), Galeno informa sobre a existência de três choroi $^{29}$ na Grécia Antiga que rivalizavam entre si: Cós, de Cnido e da Itália. Segundo o médico de Pérgamo elas competiam entre si no número de descobertas. No âmbito dessa polêmica, Bourgey (1953, p.41) oferece uma distinção entre os três tipos de medicina representados no Corpus. A primeira era a medicina de Cós, tipicamente hipocrática, que era racional e positiva; a segunda era a medicina itálica, uma vertente teórica e especulativa que se apoiavam em teorias filosóficas; e a terceira era a medicina empírica relacionada com Cnido. Robert Joly (1966, p.50) vai mais além, ele elenca várias características da medicina de Cnido e conclui que existem traços ${ }^{30}$ comuns nas obras de Cnido que testemunham uma mentalidade pré-científica nesta medicina.

\subsubsection{A teoria das três correntes de medicina: hipocrática, itálica, cnidiana.}

IIberg $^{31}$ demonstrou que dentro do Corpus hippocraticum existem obras de uma corrente cnidiana. Illberg encontrou pistas a partir dos tratados da coleção hipocrática que mostravam semelhanças entre si. Assim as Sentenças Cnidianas, obra médica não conservada, mas citada pelo autor do Da dieta nas doenças agudas, por Galeno e por Rufo de Éfeso, se converteu em ponto de referência para a distinção entre os escritos de Cós e de Cnido. Illberg $^{32}$ atribuiu à corrente de Cnido os seguintes tratados: Doenças I, II, III, Das afecções,

\footnotetext{
${ }^{29}$ I.M.Lonie (1965, p.1) deixa a palavra em seu sentido original de choros, ou seja, o antigo coro dos teatros. A tradução de Jaques Boulogne (2009, p.48) conserva o sentido de choros com a palavra francesachoeur. Jouanna (1992) e outros autores traduzem o termo por "escolas". Falar de escolas médicas ou corporações de ofício parece um tanto anacrônico, porque as corporações de ofício foram conhecidas somente no período medieval. Por isso, preferimos traduzir aqui o termo como "corrente".

${ }^{30}$ Segundo Joly (1960,p.31-69) a medicina cnidiana dos tratados Doenças II e Afecções Internas, e dos tratados de inspiração cnidiana como Doenças I e III e tratados ginecológicos, têm algumas características em comum como a polivalência causal, sobredeterminação, polifarmácia.

${ }^{31}$ Ver a introdução de Gual (2008, p.9-61). Cf. também Jouanna (2009, p.13-24).

${ }^{32}$ Quanto ao debate sobre os tratados ver I.M.Lonie (1965, p.1-30; 1978, p.42-74; 1978, p.77-92) e introdução de Gual (2008, p.9-61).
} 
Das afecções internas, Das Semanas, os tratados ginecológicos e os pediátricos. Jouanna não inclui tantas obras na corrente cnidiana. Ele (2009, p.14) parte da comparação entre a citação que Galeno faz das Sentenças Cnidianas e o capítulo 68 do tratado Doenças II. Jouanna vê, nas semelhanças dos dois textos, uma hipótese de que o texto do tratado Doenças II seja um exemplar incompleto das Sentenças Cnidianas, pois esta descrição da enfermidade lívida está perfeitamente de acordo, pelo método, pelo estilo com a globalidade da obra Doenças II.

No início, Lonie (1965, p.1-30) tentou diferenciar os tratados cnidianos dentro do Corpus hippocraticum, mas depois de alguns anos ele $(1968$, p.42) assumiu uma posição cética em relação à existência de "escolas" médicas na Grécia clássica. Ele parte do ponto de vista historiográfico e conclui que esta distinção entre obras de Cnido e Cós é um subproduto da busca pelo verdadeiro Hipócrates (1968, p.66). Seu ceticismo se baseia nas seguintes afirmações:

(a) as primeiras evidências que corroboram a hipótese encontram-se nos antigos "historiadores da medicina", como Celso, Plínio, Estrabão, Pausânias, Isidoro e Galeno. Galeno associa a razão hipocrática ao método da diairesis do Fedro e critica os autores das Sentenças cnidianas, porque eles não estão adequados ao referido método hipocrático. Portanto, Lonie deduz que a hipótese de duas escolas rivais não foi sugerida por grandes evidências na antiguidade, mas por vagos e duvidosos testemunhos;

(b) esta hipótese achou acolhida nos teóricos do século XVI, dentro de um debate entre racionalismo e empirismo, e possivelmente é mais um arranjo de evidências do que um fato histórico comprovado;

(c) segundo o testemunho de Galeno, o chefe da corrente de Cnido era Êrifon, que sendo um pouco mais velho que Hipócrates, era também o autor das Sentenças Cnidianas. Hoje se sabe que este testemunho é duvidoso, pois o autor do Da dieta nas doenças agudas nos informa que as Sentenças Cnidianas são uma obra de uma equipe ${ }^{33}$. Além disso, o testemunho do

\footnotetext{
${ }^{33} \mathrm{O}$ autor hipocrático diz (Acut.1) "estes que compuseram a obra intitulada Sentenças Cnidianas" (oi

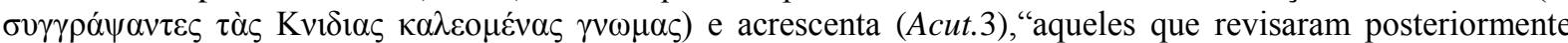

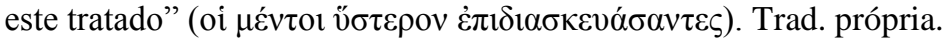


Papiro de Mênon ${ }^{34}$ (Anon.Lond. IV, 30-42), sobre Êurifon de Cnido não encontra nenhum paralelo com os tratados considerados de inspiração cnidiana (LONIE, 1965, p.30).

Mesmo ciente de toda esta polêmica, Vegetti (1965, p. 9-6; 1995, p.xiii-xiv) considera como certas algumas coisas: que existia um koinon, uma comunidade de médicos, os Asclepíades ${ }^{35}$; existia uma polêmica entre os médicos, da qual o Corpus hippocraticum é testemunha; existia um manual chamado Sentenças cnidianas; e por fim, como atesta Platão (Prt. 311b-c), Hipócrates ensinava medicina por dinheiro, portanto tinha um grupo de alunos e seguidores.

Este debate contribuiu para obscurecer cada vez mais a relação de Platão e a medicina dividindo os pesquisadores:

(a) uma parte defendia que Platão se aproxima do método de Hipócrates. Segundo estes ${ }^{36}$, o método dialético da classificação é o mesmo método da medicina hipocrática, de divisões das doenças segundo suas formas;

(b) outros acreditavam que Platão seguiu a medicina de Cnido $^{37}$. Segundo estes, na crítica que Platão faz à medicina no livro III da República, ele critica a dietética, típica da medicina de Cós, e elogia uma medicina farmacológica e cirúrgica, tipicamente cnidiana;

(c) Outros ${ }^{38}$ defenderam a influência da medicina itálica sobre Platão, principalmente no Timeu. O trabalho de Leboucq (1944, p.7-40) relaciona os fragmentos de Filistíon ${ }^{39}$

\footnotetext{
${ }^{34}$ Este papiro contém um resumo da teoria de alguns médicos gregos. Ele foi descoberto em 1890 e tinha 39 colunas. Jones (2010, p. 1-20), Jouanna (1992, p.88-91) acreditam que teria sido escrito por volta dos séculos I e II d.E.N. Ele não faz menção à Galeno, por isso é anterior a ele. Sobre a reconstituição do papiro por Diels e as falhas desta reconstituição, ver Manetti (1986, p.57-74). Para a relação do papiro e Hipócrates, ver Bourgey (1953, p.84-88).

${ }^{35}$ Examinando com cuidado a designação asclepíade, conclui-se com Longrigg (1998, p.21) e com Vegetti (1965, p.11ss) que eles designavam um genos, ou um koinon, uma ascendência comum, uma corporação ligada por relações de mestre-discípulo e não somente um grupo de pessoas ligadas por relações de consangüinidade. $\mathrm{O}$ título "asclepíades" uma espécie de sanção divina, (semelhante aos antigos aristocratas ou mesmo ao 'homéridas' que alegavam ser descendentes de Homero), que no século $\mathrm{V}$ aEN designava todos os praticantes da medicina.

${ }^{36}$ Cf. Jaeger (2001, p.1030-1); Bourgey (1953, p.31);

${ }^{37}$ Cf. Vegetti (1996, p.62-75; 1995, p.84-5)

${ }^{38}$ Burnet (1994, p.159-161) relata que Platão utilizou as noções biológicas de Alcmeon. Ver também Leboucq (1944, p.7-40), Longrigg (1998, p.53).
} 
(organizados por Wellmann), o tratado hipocrático Do coração e o Timeu de Platão. Algumas ideias como a passagem do líquido pelo pulmão seriam defendida pelos três, contudo era negada pela escola de Cós, mais especificamente pelo tratado Peri gones. Leboucq conclui dizendo que Platão não se aventura em terrenos que não dominava, por isso ele aceita um bloco de ideias de Filistíon; e assim escreve o Timeu, nome de uma personagem obscura também de Locros.

\subsubsection{A questão hipocrática e Platão: onde está o verdadeiro Hipócrates?}

Ao lado do debate sobre as escolas de medicina, mas profundamente inter-relacionado com ele, se formou um novo debate sobre a identidade e os escritos de Hipócrates. Diferente de Homero, Hipócrates é uma personagem histórica sobre a qual se possuem testemunhos de seus contemporâneos. Dois testemunhos podem ser encontrados em Platão (Prt. 311b-c; Phdr 270c-d), um em Aristófanes ${ }^{40}$ (Th. v. 272) e outro, quase meio século depois de Hipócrates, em Aristóteles (Pol. VII, 4, 1326a). Dentre todos estes testemunhos, o de Platão foi o mais interessante, pois além de confirmar a reputação do médico de Cós, descreveu o seu método.

Os classicistas voltaram a Galeno, pois ele pensava que o testemunho do Fedro era uma alusão ao tratado da Natureza do Homem. Littré (1839, p.295-313) defendeu a posição de que a citação de Platão não é literal, nem textual, mas a passagem "a natureza de todas as coisas ${ }^{41}$ " é uma alusão ao texto hipocrático Da medicina antiga (V.M. 20). Littré ganhou um grande defensor da sua hipótese, Theodor Gomperz, depois disto a questão hipocrática ficou conhecida como Littré-Gomperz ${ }^{42}$. Ludwig Edelstein (1939, p.236-48) entra na disputa afirmando que o sentido de tou holou no trecho do Fedro 270c não se referia ao Universo,

\footnotetext{
${ }^{39}$ Filístion de Locros, ou Filístion da Sicília, foi um médico cujo floruit se situa na primeira metade do século IV aEN. Foi nativo de Locros, no sul da Itália, mas viveu na Sicília. Possivelmente ele foi médico pessoal dos dois tiranos de Siracusa: Dionísio, o velho e Dionísio, o jovem. É o que deixa transparecer a segunda carta atribuída à Platão (314e), mas considerada pela maioria dos estudiosos como espúria. Segundo o testemunho de Diógenes Laércio (DL, VIII, 86), Filistíon de Locros ensinou medicina à Eudoxo de Cnido. Galeno pouco cita Filistíon de Locros, talvez porque suas obras estavam perdidas e só eram conhecidas por citações de outros autores (LEBOUCQ, 1944, p.15). Apoiando-se testemunho de Plutarco e da Oribase, Leboucq acredita que Filistíon adquiriu muita fama em vida como médico, sendo notável cirurgião e inventor de um instrumento de cirurgia; é possível que ele tenha tido também conhecimentos de dissecção. Pouco se sabe sobre sua doutrina (Anon.Lond. $\mathrm{XX}, 24)$.

${ }^{40} \mathrm{O}$ testemunho de Aristófanes foi posto em dúvida por muitos estudiosos. Para detalhes deste debate cf. Littré(1839, p.51); Jouanna(1992, p.18); Ribeiro Júnior (2005, p.19-20).

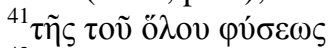

${ }^{42}$ Para maiores detalhes da leitura de Gomperz sobre o tratado Da medicina antiga, ver Vegetti (1995,p.103); Joly (1961, p.62); Gomperz (2011, p.245-76)
} 
mas à totalidade do objeto estudado. Ele conclui dizendo que não se pode relacionar o testemunho do Fedro com alguma obra do Corpus.

Nos anos seguintes, cada um dos classicistas propunha uma saída diferente. Surgiram diversas interpretações do que seria o tou holou e a qual obra hipocrática Platão teria citado ${ }^{43}$. A última grande contribuição para este debate foi em 1975, quando Lloyd demonstrou um ceticismo sobre a Questão Hipocrática em um texto denominado The Hippocratic Question. Segundo ele, o Fedro fala de um método hipocrático e não de uma teoria médica específica. Além disso, o método de Hipócrates que Sócrates descreve não se encontra representado em nenhum dos tratados hipocráticos. E por fim, se não é possível chegar a um consenso sobre o significado de tou holou, é porque a relação entre o Fedro e o Corpus é tênue (LLOYD 1991, p.203). Assim a polêmica ficou aberta.

A questão hipocrática e seus desenvolvimentos retrataram Platão também como um doxógrafo de Hipócrates, mesmo que de forma inconsciente. A relação entre Platão e a medicina se viu quase toda subsumida por uma polêmica de cunho positivista que durou mais de um século. Ainda esta discussão ecoa nos nossos dias ${ }^{44}$, talvez porque ela permanece aberta apesar dos esforços de Lloyd ou talvez porque ainda não conseguimos desvincular completamente o positivismo das questões relativas à Antiguidade.

\footnotetext{
${ }^{43}$ Joly (1961, p. 69-92) faz uma reconstrução histórica desta polêmica: em 1933, Dichgraeber se posiciona contra Edelstein afirmando que $\tau o \tilde{v}$ ö̉ov significa o Todo; Max Pohlenz (1938), por sua vez, desenvolve uma tese que

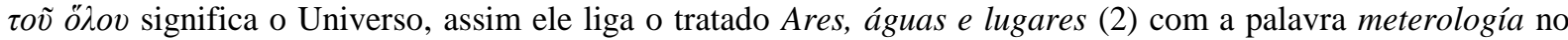
Fedro; W. Nestle diz que $\tau o \tilde{v}$ öhov significa a totalidade da coisa: o corpo estando ligado aos fatores ambientais. Joly conclui com sua própria opinião dizendo que o hipocratismo descrito no Fedro delineia um pensamento cosmológico, naturphilosophische, por contraposição ao autor Da medicina antiga, no entanto ele sugere "admettre que la doctrine du Tout ne se trouve pas telle quelle dans les oeuvres de l'École de Cos"(1961, p.92). Kucharski (1939, p.356) retoma a ideia de Littré de que Platão não está citando uma obra, mas está fazendo uma transposição. A aporia da crítica se devia à pretensão de interpretar ö̉ov $\varphi v ́ \sigma \varepsilon \omega \varsigma$ de um modo unívoco, ao invés de analisar as ambigüidades e tentar discernir o núcleo da transposição platônica. Kucharski via no tratado $D a$ medicina antiga um estímulo hipocrático para a transposição de Platão. O editor da coleção Loeb, W.H.S. Jones (1923, p.xxxv), deixa em aberto a questão manifestando certo ceticismo. Jaeger (1945, p.1030) não faz uma afirmação categórica sobre qual seria o tratado a que o Fedro fazia alusão, mas ele identificava neste diálogo as linhas gerais que remetiam à metodologia do Da medicina antiga. Ele conclui dizendo que "o método que Platão aqui define como próprio e peculiar da medicina não é outro senão o que ele próprio seguiu, sobretudo nas obras da sua última fase ${ }^{43}$, . Festugière $(1948$, p.64), em seu comentário ao tratado Da medicina antiga, toma a palavra meteorologia como "le fait de tenir des discours sublimes sur les $\mu \varepsilon \tau \dot{\varepsilon} \omega \rho \alpha$ " e $\tau o \tilde{v}$ öגov como Universo. Segundo Festugière, o método hipocrático do Fedro entra em contradição com o autor do Da medicina antiga.

${ }^{44}$ Vegetti (1995, p.97-122) irá dedicar o último capítulo do seu livro La Medicina in Platone ao Fedro. Segundo ele Platão achou em Hipócrates um método dialético ante litteram. Esta leitura se apóia sobre a aprovação de Fedro por Sócrates e sua introdução à diérese pela expressão "isso que dizem sobre a natureza de Hipócrates e

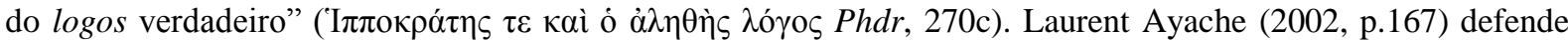
que o testemunho do Fedro se encontra em um contexto de polêmica médica e Hipócrates é invocado por Fedro, contra Sócrates, como um último recurso para refrear o ataque de Sócrates às technai e manter a posição de uma autonomia das artes. Giovanni Reale (2002, p.190-2) segue as interpretações de Jaeger. Hans-Georg Gadamer (2011, p.49-50) defendeu que "o todo" não é apenas o todo do organismo, nem "o todo" entendido como fatores climáticos e ambientais, mas conjunto da situação vital do paciente, até mesmo do médico.
} 


\subsubsection{Interpretação de Platão como "leitor" de Hipócrates.}

Enquanto os classicistas buscavam um texto no Corpus hippocraticum que fosse similar ao Fedro, os estudiosos de Platão buscavam um trecho, uma palavra, um vocabulário nos diálogos platônicos que fossem comuns aos escritos hipocráticos. Alguns pesquisadores ${ }^{45}$ atribuíram a Platão o feito de transpor o vocabulário da medicina (tais como eidos, dunamis, aitia, philosophia, areté, paradeigmata) para sua filosofia. Outros pesquisadores tentaram ver quais ideias ou doutrinas que Platão tomou emprestado ou emprestou à medicina. Jaeger (2001, p.1001) disse que poderia "afirmar sem exagero que sem o modelo da Medicina seria inconcebível a ciência ética de Sócrates, a qual ocupa o lugar central nos diálogos de Platão.” Cornford (2001, p.27-9) traça um paralelo entre Sócrates e Hipócrates, declarando que ambos rejeitavam a especulação sobre a natureza. Outras especulações se formaram em torno do tratado Da medicina antiga, uns afirmando que ele dependia de Platão (SCHIEFSKY, 2005, p.2) e outros afirmando o contrário ${ }^{46}$.

O perigo destas teorias consiste no fato que:

(a) a afinidade teórica não permite, por si só, inferir qual terá sido o sentido do influxo. Qualquer tentativa de relacionar uma obra do Corpus hippocraticum em conexão de influência com o texto platônico esbarra na insolúvel aporia de perceber exatamente quem foi o primeiro a introduzir uma determinada doutrina e quando o terá feito. Para isso é necessário que se saiba com precisão a datação das duas obras comparadas. Ora, a edição (ekdosis) não é um conceito unívoco (UNTERSTEINER, 1980, p. 37-40), o que dificulta a datação da maioria das obras ${ }^{47}$;

\footnotetext{
${ }^{45}$ Cf. Vegetti (1995, p. 61-64). Lombard (1999, p. 29, 56-57). Lombard afirma categoricamente que "Platon transpose méthode et vocabulaire de la médecine à l'art politique". Frias $(2005, \mathrm{p} .21)$ acredita que conceitos fundamentais comuns à linguagem filosófica e médica, como aitía, passaram primeiro pela filosofia e posteriormente na medicina. Garcia Gual (2008, p.110, n.2) considera eidos como um vocabulário pré-platônico. Jaeger (2001, p.1031) afirma que Platão pega o conceito de eidos do autor do Da medicina antiga(15). Burkert (1970, p.159-77) diz que a primeira ocorrência da palavra philosophia aparece no tratado Da medicina antiga. Gadamer (2011, p.49) mantém a ideia que o conceito de eidos foi utilizado primeiramente na ciência médica.

${ }^{46}$ Reale (2002, p.186) coloca Platão na posição de dependente do tratado Da medicina antiga. Reale diz: "partamos da leitura de um capítulo da Antiga medicina, que desenvolve aquele conceito-chave que particularmente no final, é expresso claramente, e do qual Platão se apropria, fundamenta e desenvolve filosoficamente."

${ }^{47}$ Para maiores detalhes sobre os métodos de datação ver Rossetti (2006, p.332-5)
} 
(b) é problemática a escassez de material textual desses temas, bem como a tradição oral na difusão de conhecimentos médicos. Algumas ideias e conceitos da medicina eram propagados pelo teatro. Além disso, os médicos se valiam das técnicas retóricas para epideixeis, para debates públicos e exposição de ideias (JOUANNA, 1992, p.109). A oralidade era um fator importante na divulgação das inovações médicas. Neste contexto é difícil relacionar duas obras pelo vocabulário utilizado;

(c) sustentar "Hipócrates disse" é confuso, pois não se sabe ao certo qual obra foi escrita pela pena do médico de Cós, será difícil provar, pelos escritos que chegaram até nós, que Platão foi leitor de Hipócrates ${ }^{48}$;

(d) Platão colheu informações de fontes variadas: das especulações médicas e biológicas dos filósofos da natureza, dos autores dos tratados do Corpus hippocraticum, da medicina popular, da tradição oral, etc. Tudo isso foi feito de diversas maneiras, em diferentes perspectivas, sempre relacionadas com a temática e com o contexto dialógico em que estão inseridas. Por isso, as indicações platônicas (VEGETTI, 1995, p.xi) correm o risco de induzir o leitor a uma supervalorização metodológica da medicina do seu tempo. Por outro lado, o testemunho platônico pode incluir uma parcialidade excessiva pelo fato de não dedicar o mesmo grau de interesse e atenção a uma série de problemas históricos e metodológicos relacionados com a constituição do saber profissional da medicina grega;

(e) Platão não é um doxógrafo (no sentido "dillesiano" do termo), antes utiliza as ideias da medicina para seus próprios propósitos, como já havia notado Kucharski (1939, p.301ss);

(f) praticamente não há uma uniformidade terminológica que permita aproximar o pensamento platônico dos escritos do Corpus hippocraticum através de semelhanças terminológicas. O próprio Galeno, mesmo exaltando Platão e Hipócrates, reconhecia que Platão tinha poucos conhecimentos da medicina (P.H.P. 3. 4). Nádia van Brock (1961, p.15), estudiosa do vocabulário da medicina grega, nota que tanto Heródoto, Tucídides, Platão, Lísias, Isócrates, Demóstenes e Xenofonte utilizavam frequentemente em seus escritos a linguagem corrente quando falavam de temas como a medicina;

(g) estas aproximações confundem a afinidade da língua com a afinidade do pensamento (SCHIEFSKY, 2005, p.2) e pressupõem que uma deriva da outra. Quando lidamos com o pensamento grego antigo (LLOYD, 1968, p.89) é sempre difícil ter certeza de quem primeiro

\footnotetext{
${ }^{48}$ Para maiores detalhes ver: Schiefsky (2005, p. 2, 46); Lloyd (1968, p.89); van der Eijk (2005, p. 1-14).
} 
utilizou uma determinada palavra com um determinado sentido. Além disso, algumas palavras da filosofia, da matemática, da medicina e da história começaram a assumir a função de termos técnicos a partir dos séculos $\mathrm{V}$ e IV $\mathrm{aEN}^{49}$. Mesmo que estes termos tenham assumido um caráter técnico, ainda continuavam carregados de um alto grau de polissemia ${ }^{50}$.

\subsubsection{Platão como cientista natural.}

Por fim, os estudiosos de Platão se perguntaram que tipo de cientista era Platão:

$1^{\circ}$. Era Platão um cientista ou um médico?

$2^{\circ}$. Platão foi o fundador da psiquiatria?

$3^{\circ}$. Por que se importar com a medicina sendo que ele advertia contra a experiência sensorial?

Para responder a primeira pergunta deve-se ter em mente que a temática "Platão e a ciência” carrega três acusações tradicionais (LLOYD, 1968, p.79):

(a) a primeira afirma que ele era desinteressado pelo inquérito sobre a natureza e que o Timeu não passa de uma bela história;

(b) a segunda afirma que ele é anticientífico, antiempírico e desqualifica as sensações e as percepções, eliminando as aparências visíveis por completo;

(c) a terceira acusação é que sua ciência natural é banal, ele simplesmente operou um amalgama das teorias dos seus contemporâneos e dos seus predecessores.

\footnotetext{
${ }^{49}$ Em Tucídides encontramos muitos vocábulos familiares aos textos hipocráticos, tais como febre $(\theta \varepsilon ́ \rho \mu \alpha l)$, vermelhidão nos olhos $(\tau \tilde{\omega} v \dot{\partial} \varphi \theta \alpha \lambda \mu \tilde{\omega} v \dot{\varepsilon} \rho v \theta \dot{\eta} \mu \alpha \tau \alpha)$, inflamação nos olhos $(\varphi \lambda \dot{\gamma} \gamma \omega \sigma l \varsigma)$. Outro paralelo entre Tucídides, os textos hipocráticos e Platão é o uso de prophasis e aitiai; cf. Lloyd (2003, p.123-4); Vegetti (2008, p.345-64).

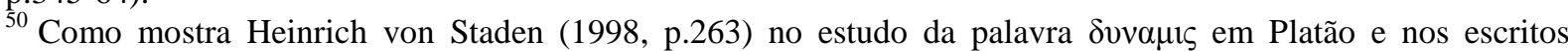
hipocráticos. Outra palavra de natureza ambígua é o pharmakon. John Scarborough (1991, p.139) explica que "the pharmakon was a plant-based drug, fundamentally ambigous in its nature." Platão explora não somente a analogia, mas a polissemia destas palavras, tais como pharmakon, katharsis, etc. (LLOYD, 2003, p.145-147)
} 
Nossa opção é ver em Platão um pensador que está comprometido com os debates que lhe era contemporâneo. Um exemplo disso é quando se analisa o Anonymous Londinenses, o leitor pode se espantar ao deparar que 177 linhas, ou seja, quatro colunas e meia foram dedicadas a Platão e somente 96 linhas, duas colunas e meia, foram dedicadas a Hipócrates. Isso alude ao fato que Platão não foi um médico prático, mas esteve interessado pelos debates da medicina. E mesmo que o testemunho de Menon seja duvidoso, não se pode duvidar que a teoria nosológica de Platão foi discutida na Antiguidade da mesma forma que Hipócrates e Filistíon de Locros.

Muitos estudiosos responderam a segunda pergunta expressando a opinião que o Timeu apresenta uma doutrina "psicossomática" que pode ser chamada de "psicopatológica", e nisto consiste a grande descoberta de Platão ${ }^{51}$. Na mesma linha de raciocínio, outros foram mais além dizendo que Platão é o pai da psicanálise ${ }^{52}$. Porém, já havia nos escritos médicos e nos filósofos da natureza uma noção de que certas desordens na psyche eram de origem física ${ }^{53}$ (LLOYD, 1968, p.87), e como vimos acima, a glorificação de Platão como "médico das almas" é uma construção da época helenística ${ }^{54}$, principalmente de Epicteto (Ench. 3.23.30). Para Platão a filosofia não é um tipo de medicina que o paciente se deita no leito e o coloca sob influência de palavras capazes de anular a culpa, os pecados, os medos e transmitir a virtude. Giovanni Reale (2002, p.243) alerta que “o discurso platônico e o psicanalítico permanece conexos a sistemas de referências conceituais e verbais totalmente diferentes". Então, se Platão não é um médico prático, nem psiquiatra, nem psicólogo no sentido moderno do termo, em que sentido é possível falar de uma medicina da alma em Platão? Sem dúvida a expressão médico das almas é platônica, porém isto será discutido com mais detalhes no capítulo 3.

\footnotetext{
${ }^{51}$ Frias (2005, p.79) apresenta Platão como original na sua reflexão sobre a relação corpo-alma.

${ }^{52}$ Jaeger (2001, p.958) diz: "Platão é o pai da psicanálise. É ele o primeiro que desmascara a monstruosidade do complexo de Édipo, a volúpia de se unir sexualmente à própria mãe, como sendo parte do eu inconsciente, que ele traz para luz por meio da investigação da experiência dos sonhos"

${ }^{53}$ Cf, Morb.Sacr. 31; Flat. 14; Heráclito DK B 117, 118; Empédocles DK B 31 A 98; Demócrito Fr. 191. A questão da saúde da alma em Demócrito é tratada com maior detalhe em Peixoto (2009, p. 55-66).

${ }^{54}$ Como foi demonstrado acima. Ver também Edelstein (1945, p. 99-100).
} 
Finalmente, a terceira pergunta causou muita estranheza ${ }^{55}$, principalmente quando alguns se deparavam com o texto onde Platão critica a medicina ( $R$. 405a - 408e). Jaeger (2001, p.798), por exemplo, mantém a ideia que Platão não quer "menosprezar o valor da função do médico ou mesmo considerá-la absolutamente supérflua", mas a profissão médica é vista de forma diferente "no Estado ideal". Uma linha de interpretação "evolucionista" defendia que Platão mudou de ideia sobre a medicina ao longo dos seus escritos (LEVIN, 2014, p.1-4). Então o debate se voltou para outro lado: a interpretação dos diálogos de Platão.

\section{PLATÃO E A MEDICINA À LUZ DAS NOVAS LEITURAS DE PLATÃo}

O trabalho de interpretar Platão é mais árduo que interpretar qualquer outro filósofo (com algumas exceções). Isso se deve porque ele sempre dirige a seu leitor de forma indireta ${ }^{56}$ (ROWE, 2011, p.28): através de diálogos, Platão jamais aparece como uma personagem. Os diálogos, embora semelhantes às peças de teatro, não são peças de teatro (ROWE, 2012, p.382-383). Eles não são representados diante de um auditório e o que está sendo dito pelos personagens exige um enorme esforço por parte do leitor para entender o que Platão está querendo dizer.

Escrever diálogos não foi exclusividade de Platão, ou seja, não foi ele quem inventou esta forma de escrita. Os escritores gregos se utilizavam de diálogos para expor uma reflexão moral e política (VLASTOS, 1994, p.77-80). Depois da morte de Sócrates, surge um gênero novo de diálogos, os Sokratikoi logoi (KAHN, 1996, p. 1-35). Os feitos de Sócrates são

\footnotetext{
${ }^{55}$ Cf. Vlastos (1994, p.99).

${ }^{56}$ Contra Strauss (1986, p.162-3). Strauss defende que Platão fala de maneira direta e indireta. Quando ele usa as expressões "eu disse", "ele disse", ele está falando de forma indireta. Caso contrário sua forma é direta. Gerasimos Santas (2010, p.2-3) fala que por indireta se entende que Platão usa seus personagens para falar com o leitor ele ilustra em um seguinte esquema:
}

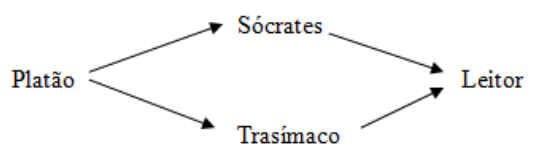


lembrados por Xenofonte, Ésquines, Antístenes, Brison, Cebes, Criton, Euclides de Megara, Fédon.

Platão foi interpretado como um escritor deste tipo de literatura socrática, que gradativamente foi se afastando do seu mestre. Outros, ao contrário, interpretaram os diálogos como uma unidade, e que Platão jamais tinha mudado de ideia. Essas duas correntes interpretativas são cruciais para compreendermos também a medicina em Platão ${ }^{57}$.

\subsection{Platão e a medicina na leitura "unitarista".}

Aristóteles foi o responsável por atribuir a Platão um conjunto de teorias e doutrinas que os diálogos não identificam como tais (SANTOS, 2008, p.21). Os interpretes antigos de Platão tendiam a afirmar que ele estava dizendo sempre a mesma coisa (GILL, 2011, p.54), condicionando o estudo dos diálogos à perspectiva unitária ${ }^{58}$. Tomavam Sócrates como sendo o principal expoente do projeto filosófico de Platão. E buscavam nos diálogos uma doutrina do autor, pressupondo que estas ideias formavam um sistema coerente de doutrinas. Esta situação modificou-se no início do século XIX com Schleiermacher.

Schleiermacher (2002, p. 27-41) propôs que o sistema de Platão fosse reconstruído a partir dos próprios diálogos e não das leituras de Aristóteles. Segundo ele, a compreensão da filosofia platônica é dificultada pelo entendimento sistemático e fragmentário, porém isso não descarta a possibilidade de existir um todo que permeia os diálogos. Schleiermacher defende que a interpretação de Platão dever seguir as seguintes orientações: contextualizar as concepções platônicas no interior da sua obra e relacioná-las com seus contemporâneos (2002, p.29); dar importância às particularidades lingüísticas do texto grego (2002, p.29); pensar a filosofia platônica como um todo onde conteúdo e forma estão intimamente ligados (2002, p.20).

\footnotetext{
${ }^{57}$ Existem outras correntes interpretativas como, por exemplo, os dogmáticos e os céticos na Antiguidade, e a tendência analítica na contemporaneidade. Cf. Gill (2011, p.53-71); Rowe (2012, p.381-395); Santos (2008, p.21-39); Trabattoni (2010, p.11-26). Contudo optei por trabalhar somente com estas duas correntes (unitarista e evolucionista), pois o debate sobre a medicina também toca na questão se Platão mudou ou não de posição sobre ela.

${ }^{58}$ É preciso ressaltar que o platonismo tinha tendia a interpretar Platão de forma unitária, mas isto não significa que o platonismo era uma corrente unitária. Havia vários platonismos (2010, p.274).
} 


\subsubsection{Interpretação "unitarista" e "esotérica".}

O trabalho de Schleiermacher impulsionou toda a história das interpretações platônicas dos séculos XIX e XX (ROWE, 2012, p. 387). Surge a corrente de interpretação "unitarista", ou seja, o fato de ler todos os diálogos como expressão de um conjunto único de ideias. Ele foi defendido por Shorey, Cherniss, Gomperz e Jaeger, e pode ser notado em Brisson e Pradeau $^{59}$. Jaeger afirmou que o objetivo da filosofia platônica era claro aos olhos do autor “quando ele empunha a pena para escrever o primeiro dos seus diálogos socráticos. Já nos seus escritos antigos se desenha com clareza total a enteléquia da República" (2001, p.606). Esta interpretação é endossada por Charles Kahn (1996, p.40-1). Ele nega que tenha ocorrido uma mudança fundamental, na posição filosófica de Platão, entre os diálogos socráticos e a República e o Fédon.

Outra versão do pensamento "unitarista" pode ser encontrada na interpretação da escola de Tübingen ${ }^{60}$. Thomas Szlezák (2005, p.87), um dos expoentes desta escola, propõe que as doutrinas de Platão mais profundas e sistemáticas, as timiotera, não são expostas nos diálogos, mas eram reservadas para um ensino oral aos estudantes mais avançados. Esta interpretação também é conhecida como abordagem "esotérica" 61 . Esses ensinos também deveriam ser transmitidos esotericamente como faziam os pitagóricos e os médicos hipocráticos (SZLEZÁK, 2009, p.18). Tudo que foi escrito por Platão deve ser complementado por argumentos melhores. Em outras palavras, o escrito filosófico não é autárquico, mas deve ser transcendido no que se refere ao conteúdo para ser amplamente entendido. O diálogo não contém este "auxílio", eles remetem a teoremas não comunicados aqui e agora. Szlezák chama isso de situação-de-boetheia, ou seja, "a situação em que um logos é exposto a um ataque e seu autor é intimado a lhe prestar auxílio" (2005, p.94).

\footnotetext{
${ }^{59}$ Pradeau afirma (1997, p.11) que "tous les dialogues platoniciens restent fidèles à cette hypothèse selon laquelle la politique relève de la penseè."

${ }^{60}$ A escola de Tübingen foi fundada por Geiser e Kraemer e reavivada por Reale (2010), tornando-se conhecida como Tübingen-Milão, e não mais somente Tübingen. No Brasil, Marcelo Perine e Dennys Xavier são os maiores expoentes da escola no Brasil. Eles têm feito um belíssimo trabalho, bucando, nos escritos de Platão e nas evidências dramáticas, as agrapha dogmata. Para um detalhe histórico da história, interpretações e refutações das teorias da escola Tübingen-Milão, ver Perine (2009, p.9-26). Para uma análise da ideia de Bem e as doutrinas não-escritas, ver Xavier (2011, p.227-238)

${ }^{61}$ Contra a interpretação esotérica ver Brisson (2003, p.55-92); Ferrari (2011, p.123-130); Trabattoni (2010, p. 21-3, 311-19); Vegetti (2003, p. 3-8, 53-65).
} 
Segundo ele esta situação-de-boetheia "é o princípio estrutural central dos diálogos platônicos" $(2005, \text { p.94 })^{62}$.

\subsubsection{A medicina na ótica "unitarista": modelo para Platão.}

$\mathrm{Na}$ abordagem "unitarista", a medicina é quase sempre reduzida a uma metáfora ou um modelo que Platão seguia (JAEGER, 2001, p.1001). A passagem da República que Platão critica a medicina quase não é lembrada.

Brisson (2011, p. 87-8) toca na medicina ao discutir sobre a ciência, os saberes, a técnica e a arte. Como é atestado na República, Platão não coloca a medicina entre as cinco mathemata (R. 522c-531a), porém Brisson de certa forma a inclui sob a forma de "Biologia", parte de uma matemática aplicada e descrita no Timeu (72e-87b), unindo assim o trecho da República ao Timeu.

A opção de Vegetti foi aceitar as contradições dentro do corpus com relação à medicina. Segundo ele (1995, p.xvi), não foi Platão quem mudou, mas a medicina hipocrática vinha modificando durante os séculos V e IV aEN. Platão estava reagindo a tais mudanças. Vegetti pergunta (1995, p.90) que coisa aconteceu no seio da medicina nos dez ou quinze anos entre o Górgias e a República ${ }^{63}$. Ele responde explicando que a medicina hipocrática, ou melhor, pós-hipocrática se tornara um ritual higiênico.

Por fim, Szlezák não toca explicitamente na relação de Platão com a medicina. Ele faz alusão à expressão "cura da alma" dentro da sua teoria esotérica: Sócrates pede a Hípias para que cure sua alma, esperando um fim da sua peregrinação. Segundo Szlezák, este fim se dá quando o dialético alcança o conhecimento do Bem ( $R$. 532e). Então, ele interpreta a exortação platônica para "salvar a alma" 64 como equivalente ao pedido para "salvar-vos" (sosai hemas) no Eutidemo (293a). As duas passagens têm a "função de desafiar o adversário a apresentar o boethein mediante timiotera, que caracteriza o filósofo como tal” (2009, p.98).

\footnotetext{
${ }^{62}$ Ver também Szlezák (2009, p.79-104). Ele também fala da "estrutura de socorro" como o fio condutor dos diálogos.

${ }^{63}$ Vegetti (1995, p.90) diz: "che cos'è avvenuto in seno alla medicina scientifica nei due o ter lustri che intercorrono fra Il Gorgia e la Repubblica, perché essa non riuscisse più a porsi como problema e com stimolo alla riflessione del filosofo?'

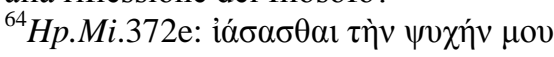


As objeções para as abordagens unitárias aparecem quando se constata que Platão frequentemente parece de fato dizer coisas diferentes em lugares diferentes. Muitas vezes parece que Platão está se contradizendo, para lidar com isso muitas vezes os "unitaristas" estabelecem unidades quase sempre arbitrárias (SANTOS, 2008, p.36). Para resolver este problema, uma das respostas mais comuns é sustentar que o pensamento de Platão passou por desenvolvimentos importantes, como fazem os "evolucionistas".

\subsection{Platão e a medicina na leitura "evolucionista".}

Segundo a linha de interpretação evolucionista, Platão teria mudado de ideia ao longo de 50-60 anos de produção filosófica. Como Wittgenstein (VLASTOS 1994, p.117) produziu criações originais em períodos diferentes da sua vida.

Guthrie (1990, p.52) defende a ideia que é natural do pensamento de um filósofo manifestar uma ordem lógica em sua evolução. Penner (2013, p. 147-199) propõe que no primeiro período da produção filosófica, Platão estaria mais próximo do Sócrates histórico. Já em outro grupo de diálogos (intermediários e tardios), Sócrates fala por Platão. E nos diálogos médios e tardios, Platão vai além de seu mestre.

\subsubsection{Pressupostos "evolucionistas" na abordagem dos diálogos.}

De certa forma, esta abordagem "desenvolvimentista" de Platão é uma estratégia para manter um tipo de abordagem unificadora e ao mesmo tempo é uma alternativa para ela (ROWE, 2011, p.30). José Trindade Santos (2008, p.23) aponta que esta abordagem implica três pressupostos não formulados:

a) A possibilidade de determinar a ordem de composição dos diálogos platônicos.

b) A ordem dos diálogos irá tornar evidente a evolução do pensamento de Platão.

c) As teses encontradas nos diálogos são de Platão e representam seu pensamento no momento em que ele compunha suas obras. 
Contudo, não é possível estabelecer a ordem de composição dos diálogos platônicos, pois é difícil determinar o que é "composição" e "publicação" na antiguidade ${ }^{65}$. É certo que eram exemplares copiados e parece não haver uma numeração das obras. Isso possibilitava a modificação dos escritos pelo autor. Dionísio de Halicarnasso (Comp.25.32) relata que Platão era um hábil revisor de suas obras, e que com oitenta anos de idade ele não deixava de polir, tecer, e reordenar os diálogos. Um exemplo disso é a existência de duas versões para o início da República ${ }^{66}$.

Frente a estas dificuldades, a estilometria se apresentou com outra via para tentar descobrir a ordem dos diálogos. Baseando na informação que as Leis foram o último diálogo de Platão, a estilometria tentou encontrar uma ordem dos diálogos observando um incremento no uso de terminologia técnica (BRANDWOOD, 2013, p.113-146). Contra este método, Kahn (1996, p.44) argumenta que desde 1896 a estilometria trouxe mais confusão e menos progresso. Nada impede que, por exemplo, Platão tenha escrito alguns diálogos ao mesmo tempo. Rowe (2012, p.392-5) acrescenta que a divisão dos diálogos proposta pela estilometria não corresponde à tradicional divisão "desenvolvimentista". Então, para continuar sustentando o evolucionismo nos diálogos platônicos, deveremos preferir os argumentos filosóficos para a datação dos diálogos. Mas tais $\operatorname{argumentos}^{67}$ são os mais fracos (ROWE, 2013, p.394).

Outro problema seria acreditar que existem teses dogmáticas nos diálogos. Não há dúvida que foi Platão que criou todas as estruturas argumentativas dos diálogos. Na crítica da poesia no livro III da República (392c-398b), Sócrates diferenciou o gênero literário da poesia narrativa (diegetica) da poesia teatral (mimética). Na primeira o autor sempre fala conduzindo a narração; na segunda, "tiram as palavras do poeta no meio das falas, e fica só o diálogo" ( $R$. 394 b) ${ }^{68}$. Mas há também um gênero misto, "diegetico-mimetico" (R. 394b-c), que resulta da combinação entre os dois outros gêneros. Os diálogos platônicos estão inseridos neste terceiro

\footnotetext{
${ }^{65}$ Cf. Untersteiner (1980, p.37-40); Santos (2008, p.23-4).

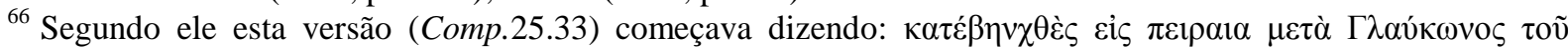

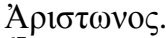

${ }^{67}$ Um exemplo clássico da datação dos diálogos platônicos pela filosofia é desenvolvido por Ross (1951, p.1-10). Apesar de Ross reconhecer a importância da estilometria, ele propõe uma ordem dos diálogos à luz da "Teoria das Ideias".

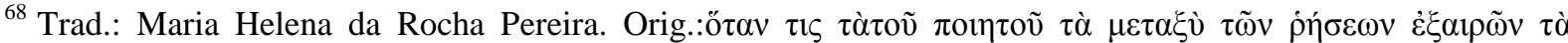

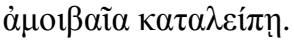


gênero $^{69}$. Neles a parte narrativa é reduzida, e muitas vezes ausente; eles se tornam parecidos com a literatura teatral (comédia e tragédia) porque imita os discursos dos personagens em cena. Contudo a "teatralização da filosofia" critica em parte a inadequação da escritura, constituindo um instrumento de persuasão. Assim, a identificação mimética vem direcionada à verdade e à justiça.

Se Platão criou todas as estruturas dialógicas, então poderemos nos perguntar se há alguma doutrina platônica nos diálogos. Parece que há teses platônicas, mas nem tudo que é colocado na boca dos personagens do diálogo representa o pensamento de Platão. Nos diálogos a maioria das ideias flui como hipóteses e não como concepções dogmaticamente impostas ao leitor (SANTOS, 2008, p.26-7).

\subsubsection{A recente crítica ao "evolucionismo" e novos caminhos para ler Platão.}

Nos últimos anos tem crescido entre os platonistas a crítica à abordagem "evolucionista"70. Além das objeções à estilometria e à ordem dos diálogos, existe outra objeção considerada por Rowe (2011, p.31) como a mais importante. Segundo esta, é implausível que Platão tenha dado as costas intelectualmente a Sócrates e ainda assim continue a usá-lo como sua personagem principal.

Mas o que fazer com as contradições (se é que elas realmente existem) dentro do Corpus de diálogos? Talvez uma opção seria buscar outra alternativa para ler Platão. Santos (2008, p.38-9) sugere que a interpretação de Platão seja feita a partir de um contexto dialético. Segundo ele, o diálogo é um complexo dramático e argumentativo que se insere em uma investigação de um tópico definido. Neste contexto dialético, as personagens estão sustentando opiniões, em um lugar e momento historicamente situados pela narrativa. Estas opiniões visam à educação, como se fossem instrumentos de ensino e investigação mais que um suporte de doutrinas dogmáticas.

Seguindo a mesma linha hermenêutica, Gill (2011, p.63-69) propõe que os diálogos sejam interpretados como "maiêuticos", ou seja, destinados a conduzir os leitores a uma reflexão filosófica autônoma. Ele estabelece quatro princípios para investigar os diálogos:

\footnotetext{
${ }^{69}$ Sobre a escritura e a forma imitativa dos diálogos, ver Dixaut (2003, p.24-33); Szlezák (2005, 13-64); Vegetti (2003, p.53-65).

${ }^{70}$ Cf. Gill (2011, p.53-71); Kahn (1996, p.1-100); Rowe (2012, p. 383-95; 2011, p. 28-39); Santos (2008, p.19$39)$.
} 
a) o conhecimento objetivo só é alcançado na participação dialética, no diálogo filosófico;

b) a dialética só pode atingir a meta se os participantes possuírem qualidades espirituais apropriadas e engajem efetivamente na forma dialética apropriada;

c) a compreensão de um problema filosófico exige que ele situe corretamente o problema em relação aos princípios da realidade e do método dialético;

d) cada encontro dialético tem sua identidade e sua significação próprias e forma um contexto para compreensão dos princípios e métodos filosóficos.

Estas considerações explicam o motivo pelo qual Platão conservou a forma do diálogo, ou seja, a investigação. Contudo, concentrar nos diálogos individuais ou selecionar passagens e contextos parece ter seus riscos (ROWE, 2011, p.38). Primeiro, porque há muitas coisas que não fazem sentido com base somente no texto selecionado. Segundo, porque existem ideias que surgem e ressurgem de uma forma ou de outra.

Em suma, seguimos a interpretação que nos diálogos platônicos a forma e o conteúdo estão harmonicamente entrelaçados, de forma que se torna difícil separá-los. Em outras palavras, a pesquisa filosófica está sempre aberta para aprofundamentos. Acrescenta-se uma segunda consideração: Platão utiliza vários métodos (TRABATTONI, 2010, p. 26) para atingir seus objetivos, por exemplo, se a intenção é criticar um sofista, ele se vale do método crítico-refutatório; se pretende argumentar a favor de um princípio moral, o diálogo assume uma dinâmica propositiva. Com isso não negamos a possibilidade de Platão ter mudado de ideia ao longo de sua vida, contudo parece ser improvável que ele tenha mudado de forma radical.

\subsubsection{A medicina segundo o "evolucionismo": craft-analogy e descontinuidades.}

Neste calor do debate hermenêutico, apareceram algumas interpretações "evolucionistas" defendendo que Platão se valia da medicina como um modelo, mas a função da técnica da medicina foi modificada ao longo dos diálogos. Este ponto de vista é defendido por Lombard. De um lado, ele parece estar próximo de uma visão "unitarista" ao sustentar 
(1999, p.56) que Platão transpôs o método e o vocabulário da medicina à arte política (ao contrário de Alcmeon de Crotona que transpôs o vocabulário da política à medicina). Lombard (1999, p.61) também vê uma continuação entre a medicina proposta por Platão e a psiquiatria. Por outro lado, Lombard (1999, p.28-9, 112-3) afirma que a medicina permite ao leitor ver uma evolução da ideia de ciência na filosofia platônica.

Já em um contexto moral, Irwin (1977, p.6-11) menciona que Sócrates apelava para um modelo de racionalidade. Este modelo era extraído das técnicas produtivas (no qual a medicina estava inserida e era a mais utilizada). Ele também é conhecido como craft-analogy. Ora, se a craft-analogy é eficaz, então a virtude será uma disciplina racional. Porém, este modelo possui vários problemas que foram levantados por Platão (1977, p.177-191). Por fim, Platão abandonou a craft-analogy na República, mas ele ainda conservou uma analogia entre justiça e saúde (1977, p.212).

Recentemente, Levin (2014, p.1-4) apresentou uma interpretação que Platão teria lançado suas bases da crítica à medicina no Górgias. Ele polemiza no Banquete e na República, mas nas Leis ele restaura o estado de techne da medicina.

Falar sobre Platão e a medicina é uma tarefa complexa e não pode ser reduzida a simples analogia ou metáfora. As referências de Platão à medicina de seu tempo se dão na pluralidade de suas motivações, que eram "epistemológicas", polêmicas, "políticas" 71 e morais. Talvez seja por isso a dificuldade em tentar sistematizar as diversas menções à medicina em todo o Corpus platônico. Nosso objetivo é analisar a polêmica que Platão estabeleceu contra a medicina de sua época a partir da República. Para isso é necessário investigar a sua recepção em um contexto de um Platão político.

\subsection{A medicina em Platão no contexto político.}

Dizer o que é política em Platão pode nos levar a outra odisséia hermenêutica que começa em Aristóteles e vai até nossos dias. Nosso propósito não é refazer este caminho, que

\footnotetext{
${ }^{71}$ Epistemologia não deve ser confundida com o debate da Modernidade e a "política" deve ser entendida em seu sentido original de cuidado da polis.
} 
já foi percorrido magistralmente pela obra de Vegetti, mas ver onde tal caminho entrou em intersecção com os debates relacionados com a saúde.

\subsubsection{Princípios para leitura da política em Platão.}

Para evitar formulações prematuras e anacronismos, deve-se ter em mente algumas indicações preliminares do que significa política em Platão. Vegetti (2010, p.32-41) elenca sete princípios para nos orientarmos em meio aos problemas que estão em jogo:

a) o que interessa a Platão na ta politika é o acesso aos cargos do poder, a finalidade dos mesmos e a estrutura econômico-social da cidade. Ele parece menos interessado em uma engenharia constitucional e legislativa;

b) o primeiro contato com a política tem um caráter diagnóstico: há uma doença na cidade;

c) Platão critica a democracia ateniense e seus maiores líderes como Temístocles e Péricles;

d) Platão propõe diversas estratégias terapêuticas para restabelecer a saúde da cidade. A República apresenta propostas terapêuticas sob a forma condicional: se..., então será preciso... ${ }^{72}$

e) para curar a cidade é necessário buscar quem possa ser aquele que irá agir como médico da cidade: no caso, o filósofo;

f) as estratégias terapêuticas variam: ora elas se destinam a curar uma cidade doente, ora elas se destinam a prevenir um surto de patologias;

g) qualquer regime político está fadado à crise e à transição para outras formas, mesmo que ele esteja próximo da perfeição.

Os temas políticos não eram secundários a Platão. Os diálogos mostram sua ocupação pela reflexão política. Contudo, nem sempre todos pensaram assim na história do platonismo.

\footnotetext{
${ }^{72}$ Cambiano (2005, p.9-24) defende que Platão utilizou o método por hipótese no livro II, aplicando um modelo geométrico na construção da cidade.
} 
No médio e neoplatonismo, a República foi quase que excluída do cânone das leituras e comentários. A República era lida de uma forma moralizante como veremos a seguir.

\subsubsection{Leitura moralizante da República e o debate sobre o vegetarianismo e saúde.}

Proclo faz uma leitura "sistemática" da República em seu comentário. Ele estabelece relações não-conflituosas entre a República e outros diálogos como o Fédon e o Timeu. Também faz uma diferenciação entre a República e as Leis (in R. 1. 11. 1-5), dizendo que o objetivo da primeira é a instrução sobre a melhor politeia $^{73}$. A unidade da cidade deve ser interpretada não no sentido material, mas em um sentido formal-final. Assim Proclo apela à cosmologia do Timeu, com o privilégio do Todo em relação aos elementos que o compõe.

Ele não desfaz a união entre alma e cidade, mas estabelece uma relação de hierarquia entre os dois. Assim a República pode ser entendida como uma metáfora dos problemas morais da alma individual (VEGETTI, 2010, p. 59). Sua leitura simbólico-alegórica da República lança bases para uma visão "moral” da saúde, visão esta que persiste até hoje.

Proclo (In R. 1. 9. 18-25) declara que a primeira dieta da cidade se aproxima da imortalidade, talvez seria por isso que Platão conjectura no Fedro (247e) que a alma se alimenta de néctar e ambrósia, símbolo da alimentação que proporcionava a imortalidade aos deuses. Cerca de duzentos anos atrás, Porfírio usara a crítica da medicina na República III com o propósito de defender o ato de não comer carne. Ele (Abst. 1. 47) faz uma ligação entre a necessidade de médicos e a multiplicação das enfermidades com a dieta cárnea ${ }^{74}$. Segundo Dombrowski (1984, p.141-143), Porfírio tece um argumento marginal de que Platão era vegetariano, mas sem nenhuma referência às fontes. Haussleiter (1935, p.184-198), por sua vez, afirma que na Vita Platonis, anônima, se aludia a uma dieta vegetariana. Porém, é difícil declarar com certeza se ele era ou não vegetariano, porque as bases são frágeis. A única passagem da República que poderia constituir um argumento para um vegetarianismo em Platão estaria no Livro X (600c) onde se fala do companheiro de Homero, Creófilo (amigo da carne), ridículo pelo seu nome e pela sua educação. Porém Haussleiter (1935, p.195) sustenta que é vaga a referência e desconfia do texto.

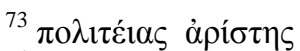

${ }^{74}$ Brisson (2006, p.133-139) toma parte nesta discussão dizendo que Platão aconselhava o vegetarianismo pela sua referência ao continuum da vida.
} 
Os debates contidos no livro III da República estariam nos dando uma pista para uma dieta salutar? Disto não temos dúvida. Porém é duvidoso que lá estaria propondo uma dieta vegetariana. Vegetti (1996, p.62; 1998, p.428) afirma que a referência à inflamação não era somente uma metáfora. Ela tinha como sua principal causa a dieta cárnea (kpreephagie). Por enquanto deixaremos em aberto esta questão, pois é necessário visitar novamente o texto à luz das novas descobertas históricas e filológicas para que o debate seja perfeitamente esclarecido.

\subsubsection{A leitura totalitária da República III: A crítica de Popper ao historicismo e engenharia} social de Platão.

No século XX, Karl Popper polemiza contra Platão, acusando-o de defender o totalitarismo e a sociedade fechada ${ }^{75}$. $\mathrm{O}$ ataque contra Platão se divide em duas: historicismo e engenharia social utópica.

a) Segundo Popper, o historicismo é uma doutrina em que a história "é controlada por leis históricas ou revolucionárias específicas, cujo descobrimento nos capacitaria a profetizar o destino do homem" (1974, p.22). Contudo, Platão não é um historicista integral, ou seja, ele acredita que a história possa mudar pela vontade moral do homem (1974, p.34). Ele se torna tão pessimista quanto Hesíodo, mas ele vai além. Platão oferece uma "teoria da mudança": a história tende para a degeneração por causa do fluxo de todas as coisas sensíveis. Popper (1974, p.54) conclui:

Como se pode ver da última observação, Platão encara a histórica, que para ele é uma histórica da decadência social, como se fosse a história de uma doença: o paciente é a sociedade; e como veremos mais adiante, o estadista deveria ser um médico (e vice-versa) - um curador, um salvador.

\footnotetext{
${ }^{75}$ Sobre a interpretação de Popper ver Vegetti (2010, p.175-192).
} 
Popper está convencido que Platão queria curar a doença social do seu tempo voltando para a sociedade primeva, para uma antiga forma tribal de vida social (1974, p.69). Esta forma tribal se identifica com a "cidade de porcos" e com a comunidade de bens onde o rei-filósofo (ou rei-sacerdote tribal, uma espécie de xamã) governaria.

b) Outra acusação de Popper é atribuir a Platão um esboço de uma engenharia social utópica. A estrutura desta engenharia utópica tem como base teórica a teoria das Formas (1974, p.3948), pois segundo esta teoria existe um primado do Estado perfeito, imutável e invariável. Popper crê que esta engenharia social se dá através de um esteticismo, ele precisa purgar a cidade como o médico purga a doença:

O exemplo é bem escolhido, pois Platão gosta de visualizar sua missão política como a do curador ou salvador do corpo enfermo da sociedade. Fora isso, o papel que ele destina à medicina lança luz sobre o caráter totalitário da cidade de Platão, em que o interesse do estado domina a vida dos cidadãos, desde o casamento de seus pais até o túmulo. Platão interpreta a medicina como forma de política, ou como ele próprio encara 'Esculápio, o deus da medicina, como um político.' A arte médica, explica, não deve considerar o prolongamento da vida como o seu alvo, e sim o interesse do estado. (...) Em conseqüência, o médico 'não tem o direito de atender a um homem que não possa desempenhar seus deveres normais, pois tal homem é inútil para si mesmo e para o estado'. (...) Com relação ao uso das mentiras e enganos, Platão insiste em que estes são 'úteis apenas como remédio'; mas o governante do estado, frisa Platão, não deve comportar-se como alguns desse 'médicos comuns' que não tem coragem de administrar remédios fortes. (...) Que espécie de mentiras tem Platão em mente quando exorta seus governantes a usarem remédios fortes? (...) Platão (...) expressa sua esperança de que mesmo os próprios governantes possam ser induzidos a crer, pelo menos após algumas gerações, na sua maior mentira propagandística: quero dizer, seu racismo, seu Mito do Sangue e do Solo, conhecido como Mito dos Metais no Homem e dos Filhos da Terra. (...) O motivo para que 
Platão deseje que os próprios governantes acreditem na mentira da propaganda é sua esperança de aumentar-lhe o efeito salutar, isto é, fortalecer o regime da raça de ambos e, por fim, deter toda mudança política.

Para Popper, Platão está convencido que é preciso recorrer à força para resolver as dissensões. Então, Platão teria buscado na medicina um modelo para uma política genocida. Deve-se levar em consideração a época em que Popper viveu, as fontes que ele utilizou e a imagem de Platão que ele tinha. Não queremos fazer uma apologia à Popper, mas esta passagem onde Platão ( $R$. 407d-e) proíbe que se cuide de um enfermo já tomado pela doença e não deixe que ele tenha filhos, causa, em nossos dias, estranheza a qualquer um que lê.

Popper também não sai muito fora da tradição. Averróis (2011, p.32-3), em seu comentário à República, deixa claro que o médico deve separar do corpo os membros que estão necrosados, como por exemplo, os dedos gangrenados e os dentes cariados. Assim também, continua Averróis, na sociedade modelo é preciso que os médicos curem as lesões traumáticas e se faça o diagnóstico das enfermidades identificando quais são as doenças crônicas. E os deficientes devem ser eliminados. Pois, só existe uma finalidade do cidadão: viver em sociedade e participando dela. Se esta finalidade desaparece, a morte é preferível à vida.

De que forma, então, se pode responder aos ataques tão ferrenhos que Popper desferiu contra Platão? Talvez a forma mais fácil seria dizer que o texto está inserido em um contexto histórico e que não tem nada mais para nos oferecer. Ou despolitizar completamente Platão, dizendo que o sentido era estritamente moral ${ }^{76}$ ou irônico. Contudo o risco de estar traindo o texto do diálogo platônico é tão real quanto o da interpretação popperiana.

\subsubsection{A ironia na República III: interpretação de Leo Strauss.}

Strauss (1986, p. 149-153) interpreta Platão como um filósofo que não propõe uma tese na primeira pessoa, mas escolhe Sócrates, um mestre em ironia, para ser o seu porta-voz

\footnotetext{
${ }^{76}$ Para maiores detalhes sobre a defesa contra os ataques de Popper ver Vegetti (2010, p.193-256).
} 
por excelência. A ironia, segundo Strauss, é uma espécie de dissimulação. Então falar pela boca de um homem, célebre por sua ironia, significa não dizer nada.

Strauss passa a analisar a República, e nota a proximidade entre este diálogo e a Ecclesiauzuse de Aristófanes (1986, p.169). Platão estaria refutando também As Núvens, e a República seria uma versão platônica do Discurso Justo. ${ }^{77}$ Trasímaco era a encarnação da injustiça. Ele seria uma imagem da cidade (1986, p.197). A fúria de Trasímaco era a fúria da cidade contra Sócrates, o que culminou no seu processo, julgamento e condenação à morte.

A aproximação do diálogo e da comédia está sugerida pelo ridículo evocado em cada diálogo. Cada diálogo trata de uma parte; desenvolve a verdade de certa parte. Mas a verdade de uma parte é uma semi-verdade. Então, cada diálogo faz uma abstração de alguma coisa que é de suma importância para o tema do diálogo (1986, p.170). Assim, esta abstração torna impossível a solução do problema posto no diálogo. E o impossível (ou certa espécie de impossível) é tanto ridículo como cômico.

A República é um diálogo indireto que fala sobre a justiça (1986, p.170). Então, a solução política do problema da justiça é uma abstração, por consequência ele é impossível. O projeto da cidade construída "em discursos" ou a "cidade justa" se torna impossível. A análise de Strauss exerceu uma enorme influência na tradição americana, criando alguns dogmas em torno da interpretação de Platão (VEGETTI, 2010, p.215):

a) o caráter irônico-cômico, dissimulador e a intenção autorrefutadora da República;

b) a kallipolis não é possível, nem desejável, pois ela é contra a natureza;

c) a política é inferior à filosofia e possui limites.

Quanto à medicina, Strauss faz uma minuciosa análise da saúde na República durante uma série de palestras realizadas na universidade de Chicago em 1957. Ele parte de dois pressupostos (2014, p.91): que Platão está exagerando na República; e que o objetivo da República é a justiça e não o melhor regime. Strauss (2014, p.88-92) desconfia da condenação

\footnotetext{
${ }^{77}$ A análise do straussiano Allam Bloom (1991, p.307) sobre a República segue o pressuposto que este diálogo é uma verdadeira apologia a Sócrates.
} 
que Platão faz da medicina pós-homérica, e consequentemente do elogio que ele faz à medicina homérica. A condenação da teologia homérica está relacionada com a condenação da medicina homérica. De fato, Platão estaria: elogiando a medicina pós-homérica por ter se separado da política; elogiando o tratamento de Heródico de Selimbra; e demonstrando como a medicina homérica era imperfeita.

\section{ALGUMAS CONCLUSÕES PRELIMINARES.}

Interpretar Platão não é fácil. Ainda mais difícil é falar da medicina em Platão em meio às diversas interpretações antigas e modernas. Desde a antiguidade, Platão foi ligado à medicina. Esta ligação se deu de duas formas: uma interpretação "psicológico-salvífica", na qual Platão era um médico das almas que tratava da tristeza humana; outra interpretação "físico-biológica", onde Platão possuía uma teoria própria sobre a medicina. Porém, foi Galeno que uniu Hipócrates e Platão explicando que este último foi seguidor do primeiro e se apropriou de sua doutrina.

Toda uma tradição posterior interpretará a relação de Platão com a medicina incluindo Hipócrates de Cós, a quem Platão faz menção duas vezes. No século XIX, os classicistas reacenderam o debate sobre a busca do verdadeiro Hipócrates e os escritos derivados diretamente de sua pena. Para isso evocaram Platão, pois ele é o único contemporâneo do médico de Cós que testemunha sobre o método hipocrático no Fedro. Paralelamente, discutese sobre o médico de Cós como um rival de duas outras escolas: Cnido e Itálica. Platão foi visto como defensor da escola de Cós, de Cnido ou da escola Itálica. Todos estes debates permanecem abertos.

De outro lado, dentro da tradição hermenêutica do platonismo, as leituras "unitaristas" e "evolucionistas" não deixaram de intervir na questão de duas formas: de um lado dizendo que Platão utilizava a medicina como um modelo por todo o corpus; e de outro lado afirmando que Platão mudou de ideia, ou seja, tinha a medicina como um modelo nos diálogos da "juventude", mas a abandonou nos diálogos da "maturidade", e por fím retornou à 
medicina nos diálogos da "velhice". Todas estas interpretações possuem dificuldades que as tornam, em última análise, insatisfatórias.

Permanece o convite para o que diálogo platônico seja interpretado mais como um instrumento de investigação do que uma doutrina dogmática. As personagens sustentam opiniões diversas em contextos variados. Cada problema aparece e reaparece em situações diferentes. Para isso Platão utiliza vários métodos: mitos, analogias, elenchos, entre outros.

A menção de Platão à medicina não se dá de forma sistemática em todos os diálogos. O que não quer dizer que Platão estaria mudando de ideia, mas ele aplica a medicina conforme seus propósitos. Não é nosso objetivo mostrar como isso se deu em todos os diálogos. A delimitação do tema se dá a partir da critica à medicina no Livro III da República, de onde partiremos com o pressuposto de que Platão não está utilizando a medicina como modelo conforme a tradição afirma, mas polemizando com ela.

O texto delimitado não é simples, pois Platão critica a ideia de progresso a qualquer custo, o surgimento de novas doenças, a medicina dietética, a rapinagem dos médicos e propõe uma reeducação de todo "sistema de saúde" da polis. É preciso agora analisar com cuidado cada um destes tópicos em seu contexto, confrontando o texto com os escritos da época, principalmente o Corpus hippocraticum. Nesta análise encontraremos algumas pistas que podem dar algumas respostas aos ataques de Popper e às leituras de Strauss, que fazem do diálogo uma simples ironia.

Deve-se ter sempre em mente que a polêmica platônica à medicina está inserida em um contexto político, onde se investiga o que é a justiça. Platão utiliza a imagem da medicina na República de várias formas: como analogia (craft-analogy) no debate com Trasímaco; como um analogon ou uma metáfora da justiça. Porém, vale ressaltar que mesmo quando ele inclui a medicina em uma metáfora ou analogia, ele o faz de forma polêmica.

Finalmente, podemos acrescentar que a crítica à medicina, apesar de estar inserida no contexto de educação dos guardiões da cidade, é muito mais profunda e está ligada a toda uma estrutura argumentativa que envolve temas complexos como a alma e a política, e que muitas vezes vai além do livro III da República. Para demonstrar isso, iremos provar daqui em diante que o recurso à medicina era muito mais que estilo ou uma "ajuda". Platão prepara na República um arsenal argumentativo e conceitual sobre os médicos e a medicina que difere da maioria dos textos hipocráticos escritos nos séculos V e IV aEN. 


\section{CAPÍTULO SEGUNDO}

\section{A MEDICINA NA REPÚBLICA: ANALOGIAS E POLÊMICAS.}

A República de Platão é um diálogo onde se cruzam diversos temas e conceitos. A tradução de Politeia para o latim Respublica trouxe alguns mal-entendidos ao longo do tempo. Havelock (1963, p.3-5) acreditava que este título não reflete com fidelidade seu conteúdo, pois somente um terço da República diz respeito propriamente à questão do Estado ${ }^{78}$.

É quase unânime entre os estudiosos ${ }^{79}$ a afirmação de que o texto da República, apesar de ter como fio condutor o tema da justiça, traz uma grande quantidade de assuntos que dizem respeito à "condição humana", como a alma, o conhecimento, entre outros. Isso não quer dizer que a política é um tema secundário. Mas a política em Platão deve ser entendida como foi exposto no capítulo anterior.

Provavelmente Platão não escreveu a República de uma só vez. A teoria mais aceita é que a data da sua composição esteja situada entre a primeira e a segunda viagem de Platão a Siracusa, entre 390 e 370 a. $C^{80}$. Porém todas estas datas são conjecturas e nada impede que Platão estivesse sempre revisando suas obras ${ }^{81}$. Talvez a República tenha sido escrita ao mesmo tempo que outros diálogos, podendo até ter ocupado o seu autor ao longo de toda a sua vida.

Guthrie (1992, p.419-20) defende que talvez Platão não tivesse consciência de uma data dramática, pois a República está repleta de uma atmosfera moral e política da época de Platão, e ao mesmo tempo impregnada de uma conversação fictícia. Talvez os argumentos de Guthrie não sejam convincentes, mas uma coisa é certa: é difícil precisar a data dramática. Debra Nails (1998, p.383-96) nota vários anacronismos na República: Céfalo está vivo ainda

\footnotetext{
${ }^{78}$ Não se trata do Estado moderno (pós-Hobbes), mas sim de um conceito abstrato que traduz 'o conjunto de cidadãos', isto é, a soma de todos os que têm participação política.

${ }^{79}$ Ver Crombie (1962, p.85-88); Santas (2010, p.5-8); Vegetti (2010, p.274); Vegetti (2011, p.18).

${ }^{80}$ Para a datação ver Casertano (2011, p.10-11); Vegetti (2011, p.3-5); Crombie (1962, p.25); Guthrie (1992, p.419-20); Santas (2010, p.1) propõe que a data da República seja simultânea à fundação da Academia.

${ }^{81}$ Até mesmo o método da estilometria demonstra que existem rastros de estilos da maturidade, da juventude na obra platônica, cf. Brandwood (2011, p. 145); Guthrie (1992, p.419).
} 
(a possível data da sua morte é 443); a primeira celebração da deusa Bêndis (429/8); a batalha de Mégara em que Glauco e Adimanto se destacaram (424 ou 409). Talvez estes anacronismos indiquem a possibilidade de ter existido uma "proto-República" (NAILS, 1998, p.391).

Sendo assim, é difícil precisar se Platão polemizava contra uma obra específica do Corpus hippocraticum. Contudo, Platão não estava alheio às discussões dos séculos V e VI. Tais discussões aparecem tanto na República como nos escritos médicos. Além disso, é notável na República um tratamento especial de conceitos de medicina, saúde e médicos. As analogias e as metáforas serviam para polemizar contra os saberes dos sofistas, mas também para estabelecer o que é saúde e quem são os bons médicos.

\section{MEDICINA ENTRE METÁFORAS E ANALOGIAS.}

No plano analógico a medicina está inserida em duas "metodologias" na República: craft-analogy e analogon. A craft-analogy, ou a analogia das técnicas, se desenvolve no Livro I em torno da discussão entre Sócrates e Trasímaco. Já o analogon se desenvolve no Livro III, onde Platão estabelece um paralelo entre o "sistema judiciário" e o "sistema de saúde". Contrariando a tese de Irwin (1977, p.177-191), defendemos que a mudança de craft-analogy para analogon não é um indício que Platão esteja rejeitando as ideias de Sócrates. Platão pode, simplesmente, estar operando uma mudança de método para um propósito específico no qual a polêmica contra a medicina ocupa um lugar especial, como veremos.

\subsection{Medicina como craft-analogy.}

O termo craft-analogy foi amplamente desenvolvido por Irwin (1977, p.6), apesar de não ter sido ele o seu criador. Seu modelo "evolucionista" da craft-analogy suscitou várias críticas ao longo das últimas décadas. Nussbaum (2009, p.83-4) argumenta que a palavra 
inglesa craft não é exata para exprimir o sentido de techne. A techne inclui o sentido de artifício, arte e ciência. De tal forma que na época de Platão não há uma distinção sistemática ou geral entre episteme e techne ${ }^{82}$. Ao contrário, Platão testemunha um alargamento semântico da palavra que foi paralelo à progressiva especialização das profissões (CAMBIANO, 1991, p.16). Então, conclui Nussbaum (2009, p.86), a ideia de craft aplicada à techne fez com que Irwin incluísse a noção de fim no seu conceito. Outra objeção (ROOCHNIK, 1998, p.1-15) foi baseada no fato de que a craft-analogy possui vários estágios nos diálogos de Platão. Acrescenta-se que mesmo nos diálogos chamados da "maturidade" e da "velhice" as technai providenciam um modelo positivo para o conhecimento moral. Graham (1991, p.16-23), por exemplo, identifica um modelo da craft-analogy até mesmo no Timeu.

Existe um debate sobre a techne em Platão, e sem dúvida a medicina faz parte deste debate. Causa estranheza quando Platão exclui a medicina da lista das cinco mathemata ( $R$. 522c-531a) e das technai (Phlb. 55d-56b). Esta exclusão parece parte de um desdobramento da polêmica existente no âmbito conceitual, das práticas médicas nos séculos V e IV e da afirmação de autoridade em assuntos relativos ao ser humano. Não é possível aprofundar neste debate o papel e estatuto das technai no pensamento platônico, pois não é o assunto da nossa presente investigação.

Contudo não se pode passar ao largo da discussão sobre a função da craft-analogy no Livro I da República. Esta função está intimamente ligada ao papel de Trasímaco e ao papel do Livro I na obra em geral.

\subsubsection{O papel do Livro I na República.}

Acredita-se ${ }^{83}$ que o Livro I foi escrito anteriormente como um diálogo socrático independente, talvez intitulado Trasímaco. Outra versão mais moderada ${ }^{84}$ diz que o Livro I foi posteriormente anexado, com algumas modificações, no corpo da República. O argumento desta interpretação se baseia:

\footnotetext{
${ }^{82}$ Sobre o sentido da palavra techne em Platão ver: Cambiano (1991, p.61-84); Vegetti (1998, p.193-207); Roochnik (1998, p17); Nussbaum (2009, p.83-88); Brisson (2010, p.70-72)

${ }^{83}$ Essa tese foi defendida por Dümmler (Apud: GUTHRIE, 1995, p.419), o qual batizou o livro com o nome de Trasímaco.

${ }^{84}$ Defendida por Vlastos (1994, 341-4), Casertano (2011, p.11).
} 
a) no ambiente social e cultural da Atenas do século V;

b) na refutação socrática, o elenchos, e na conclusão aporética;

c) na constante referência de Sócrates à craft-analogy;

d) na ausência de temas como a tripartição da alma ou a Teoria das Formas;

e) nas questões “o que é $x$ ?”

Contra esta interpretação e a favor da unidade do Livro I com os livros I-X, existem várias evidências ${ }^{85}$, entre as quais podemos citar:

a) o Livro I é rico de temas que serão desenvolvidos nos próximos livros;

b) há uma antecipação da kallipolis (347d) e do poder do filósofo teorizado no livro V;

c) existe uma antecipação da teoria da alma dividida e conflituosa (352a);

Além destas interpretações, acrescenta-se a leitura de Szlezák (2009, p.287-294) que sugere a estratégia do "socorro", ou seja, o ataque ao resultado e o seu "socorro" bemsucedido pelo recurso. Assim, Szlezák conclui que a aporética e a construção positiva da teoria representam dois graus do mesmo método geral. Kahn (1993, p.131-142) apresenta uma interpretação segundo a qual o Livro I consiste em um proêmio onde Platão conecta a República com os diálogos socráticos, servindo como um resumo ou uma recordação. Sobretudo existe um problema que fica sem solução: por que Platão decide abrir a República com um diálogo socrático?

Entendendo "Sócrates" como uma personagem do diálogo, podemos tentar responder que Platão decidiu revisitar o estilo socrático para mostrar a eficácia da problematização (VEGETTI, 1998, p.17-19). O elenchos socrático serve para abrir um questionamento neste

\footnotetext{
${ }^{85}$ A favor da unidade ver Gutrhie (1995, p.419).
} 
caso da justiça, e refutar opiniões (de Céfalo, Polemarco e Trasímaco). Quanto às objeções de Glauco e Adimanto, no Livro II, elas exigiriam outra abordagem, uma vez que implicam uma maior elaboração "teórica”. Portanto, Platão não estaria rejeitando Sócrates, mas trabalhando com diferentes métodos para um "auditório" diferente.

\subsubsection{O propósito da personagem Trasímaco.}

No Livro I, Sócrates desce ao Pireu para ver a festa da deusa Bêndis. No retorno para Atenas, ele é obrigado (por Polemarco, filho de Céfalo) a ficar. Sócrates encontra-se na casa de Céfalo com Trasímaco de Calcedônia. A discussão sobre o que é a justiça se inicia com Céfalo, que logo abandona e passa para Polemarco. Trasímaco entra na discussão, furioso, bradando em alta voz (336b-d).

Trasímaco era sofista natural de Calcedônia, na Bitínia, colônia de Megara ${ }^{86}$. Exerceu atividade em Atenas por volta do ano $427 \mathrm{aEN}$, pois foi citado por Aristófanes na sua comédia Convivas. O discurso Sobre a Constituição (peri politeias) o coloca durante a Guerra do Peloponeso. Na República, Trasímaco sustenta a posição que a justiça é "a conveniência do mais forte". Muito se discutiu sobre o Trasímaco "histórico". O seu discurso Sobre a Constituição (U B1) nada fala sobre a sua posição defendida na República. Chegou-se até a pressupor a existência de dois Trasímacos (MACÉ, 2009, p.9): o orador e o sofista. Tudo isso parece fazer parte de um esforço em redimir Trasímaco das acusações de Platão ${ }^{87}$. Na República, diz Guthrie (1991, p.275), "Platão mostrou seu lado pior talvez se apoiando em coisas que ele disse ou escreveu quando Atenas estava no clímax de seu poder e arrogância”.

Sem dúvida, Trasímaco é uma personagem construída por Platão para seus propósitos (QUINCEY, 1981, p. 300-315), que pode ser ou não identificada com o Trasímaco "histórico". Também não se pode identificá-lo com o Cálicles do Górgias, como pensa Schofield (2008, p.204) ${ }^{88}$. Mais do que isso, parece que Platão queria identificar em Trasímaco as teses

\footnotetext{
${ }^{86}$ Para a vida e obra de Trasímaco ver Guthrie (1995, p.272-5); Untersteiner (2012, p.441-4); Macé (2009, p.932); Romilly (1998, p.169-176, 182-5, 251-4, 310-3).

${ }^{87}$ Esta posição é defendida por Guthrie (1995, p.272-5), Kerferd (1964, p.12-16) e Untersteiner (2012, p.441-4).

${ }^{88}$ Schofield (2008, p.190ss) defende uma reminiscência no Livro I da República. Ele vê um paralelo com as personagens do Górgias. Assim Polo é ligado à Céfalo e Calicles à Trasímaco. Contra Schofield ver Romilly (1988, p.172-6).
} 
difundidas no ambiente intelectual da época da crise da polis, pois estas apareciam também no discurso Sobre a verdade de Antifonte, em Tucídides ${ }^{89}$ e nos escritos hipocráticos.

Trasímaco defende duas teses principais: a) O justo é a conveniência do mais forte ${ }^{90}$; b) a justiça e o justo são um bem alheio (343c). Durante a defesa das suas teses, Trasímaco constantemente apela para que Sócrates use argumentos claros e rigorosos ${ }^{91}$ e também um raciocínio correto $^{92}$. Toda esta linguagem (saphes, akribes, orthos) faz parte de um pano de fundo intelectual do século V, e aparece nos escritos médicos (VM 1, 9, 13; Aër 1; Prog. 25), no programa metodológico de Tucídides (2. 40), em Protágoras (DK A10) e em Pródico (DK A11, 16).

\subsubsection{O propósito da craft-analogy no Livro I.}

Agora estamos em condições de demonstrar o propósito da craft-analogy no Livro I: metodologia do elenchos socrático para refutar opiniões como as dos sofistas, de alguns médicos hipocráticos e dos sofistas.

O apelo às analogias é recorrente na argumentação de Platão desde os "Diálogos Socráticos" até as Leis. Tais imagens não devem ser entendidas como meros ornamentos de estilo, vazias em si mesmas. A analogia possuía um papel fundamental na literatura grega e serviu para um desenvolvimento da especulação cosmológica. Podemos enumerar ao menos três funções da analogia:

a) ela serve para nomear um objeto através da semelhança com outro. Muitos nomes de doenças tinham relação com coisas ou fatos da natureza das quais elas se assemelhavam (LLOYD, 1966, p.177-8);

b) ela era usada para conceber e descrever o desconhecido (LLOYD, 1966, p.192-209). Em outras palavras, o mundo externo possui muito mais que ilustrações para compreender fenômenos obscuros;

\footnotetext{
${ }^{89}$ Como demonstra Vegetti (1998, p.235-7) e Romilly (1998, p.169-176)

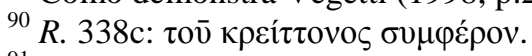

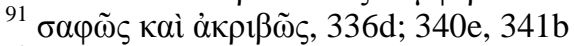

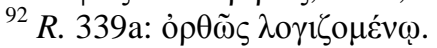


c) o reconhecimento de semelhanças entre dois objetos pode servir como base para explicar um deles ou a causa de um fenômeno. Um exemplo disso pode ser extraído do tratado Dos ventos. O autor (Flat. 8), ao explicar o porquê das pessoas bocejarem antes da febre, compara o ser humano em estado febril com uma caldeira. Assim como o vapor de água sobe das caldeiras quando a água ferve, também o corpo aquecido solta um ar concentrado pela boca.

Porém nem sempre a metáfora era clara ou esclarecedora. Nem sempre os escritores gregos faziam uma distinção entre o que era "literal" ou "primário" e o que era "metafórico" e "secundário". Platão (Sph. 231a) reconhecia que o homem deveria ter cautela com a semelhança (homoiotetas), pois é fonte de enganos ${ }^{93}$. Ele deixa claro que certas analogias não podem ser aceitas sem uma devida verificação (R. 368e). Mas ele recomenda o seu uso (Plt. 277d) para demonstrar ideias importantes. Além disso, ele jamais cessou de usar analogias para demonstrar noções políticas e éticas (Plt. 295b-c, Lg. 691c, 709a, 720a, 961d, 765e, 840d-e), assim como para falar sobre a Forma do Bem (R. 506d) e de questões acerca da alma (Phdr. 246a).

A craft-analogy permite que Sócrates demonstre suas conclusões, mesmo que aporéticas. Ela também constitui em um poderoso arsenal contra os sofistas (GRAHAM, 1991, p.14) criticando, provando, provocando, e muitas vezes ironizando o movimento sofístico e os saberes que surgiam na Grécia de sua época.

\subsubsection{A medicina nos argumentos desenvolvidos pelacraft-analogy no Livro I.}

Diversas teses foram colocadas na boca das personagens, algumas das quais encontram certa relação com as crenças e as ideias relativas à saúde, presentes nos séculos $\mathrm{V}$ e IV. A primeira delas se desenvolve em confronto com Polemarco ( $R$. 332a-e) a partir da especulação do que Simônides disse a respeito da justiça:

a) Simônides afirmava que justiça era devolver a cada um, o que lhe é devido.

\footnotetext{
${ }^{93}$ Ver também, Phdr. 262a-c.
} 
b) Se perguntássemos a Simônides o que seria a medicina, possivelmente ele responderia que é a arte que dá ao corpo os remédios, os alimentos e as bebidas.

c) Analogamente, a justiça seria distribuir aos amigos e aos inimigos os benefícios e os danos.

d) Assim como o médico é capaz de fazer o bem aos amigos doentes e o mal aos inimigos, no que respeita à saúde e à doença (assim como a culinária dá o tempero às comidas), também o justo é capaz de servir os amigos e prejudicar os inimigos na guerra.

e) Então o justo é inútil no tempo de paz? Polemarco responde negativamente.

Não se deve pensar que a interpretação de Simônides que Platão coloca na boca de Polemarco sobre a medicina é uma das "teses" platônicas. As afirmações "b, c e d" lembram algumas noções desenvolvidas nos séculos V e IV: alusão à culinária como techne mageirike ${ }^{94}$; a prática farmacológica e dietética da medicina; a crença de que os médicos poderiam fazer mal, visto que manipulavam pharmaka.

A desconfiança nos médicos é confirmada em várias passagens do Corpus Hippocraticum, no Górgias de Platão, nas Fábulas de Esopo e em Heráclito. No Górgias (456b) lê-se que existem doentes que recusam tomar remédio, se submeter à cirurgia e à cauterização. Na Fábula 170, o doente pergunta ao médico como estava, pois este suava mais que o normal, sentia calafrios e sofria de diarréia. $\mathrm{O}$ médico lhe respondera que tudo aquilo era bom e, por fim, o doente exclama: "eu morro de tão bem que estou". Heráclito (DK B 58) também testemunha este receio dos tratamentos dizendo que os médicos cortam, queimam e torturam seus doentes. Os procedimentos, a taxa de sucesso ou fracasso das terapias e a própria ambiguidade da palavra pharmakon ${ }^{95}$ pareciam aterrorizar muitos pacientes.

Mas talvez seja no tratado Da arte que encontramos um dos maiores testemunhos de um ataque contra os médicos. $\mathrm{O}$ autor do tratado diz que estes detratores da medicina, com discursos empolados, apontam não somente o doente como causador da própria morte, mas também o exercício da arte medicinal (de Arte 7). Possivelmente muitos acreditavam na falha da arte médica. Isso se reflete no segundo e terceiro argumento de Trasímaco.

\footnotetext{
${ }^{94}$ A medicina aparece como um desenvolvimento da culinária conforme mostra o texto Da medicina antiga, 3-5.

${ }^{95}$ No Elogio de Helena, Górgias faz alusão a esta ambivalência dizendo que "alguns remédios extraem alguns humores do corpo, uns acabando com a doença, outros com a vida" (tradução própria seguindo Untersteiner: $\tau \tilde{\omega} v$

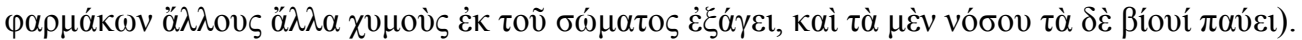


Trasímaco defende que (338c-339e) a justiça é a vantagem daquele que é mais forte, enquanto Sócrates contesta, dizendo:

a) Se a justiça é vantagem do forte, que estabelecem leis para sua vantagem, então é justo obedecer aos legisladores.

c) O legislador comete erros, até mesmo nas leis.

d) A lei incorreta não é vantajosa para o legislador.

e) Como é justo obedecer a todas as leis, logo é justo legislar contra a conveniência do legislador.

Com a refutação, Polemarco já proclama Sócrates como vencedor. Trasímaco objeta apelando para a craft-analogy. Ele afirma que é por modo de falar que dizemos que o médico se engana. É que o médico, o artesão ou o governante jamais se enganam no exercício da função. Se ele erra, deixa de ser médico (340d-e). Sócrates concorda com o fato de a medicina não ser defeituosa (342a-b), e nenhuma arte possui sinal de falha ou imperfeição. Com base nestas asserções, o argumento se desenvolve da seguinte maneira:

a) O médico (que não erra) trata do corpo doente. O piloto governa os marinheiros.

b) Todas as technai são orientadas para a vantagem do objeto que lhes é exterior.

c) Nenhuma tecnhe considera sua vantagem.

d) A justiça é techne, logo a justiça não propõe nem ordena sua própria vantagem.

Encontramos aqui uma polêmica contra ideias defendidas no tratado Da medicina antiga. Segundo o autor hipocrático, a certeza é difícil e o médico comete erros (VM 9): 
Por isso, resulta em um duro trabalho adquirir o domínio de uma ciência com tal precisão que não possa cometer ligeiros erros aqui ou lá; quanto a mim, eu louvaria o médico cujos erros foram mínimos. Pois é muito difícil discernir onde está a certeza verdadeira. ${ }^{96}$

Segundo este tratado a techne é confiável, mas não totalmente. A exatidão da medicina, a akribeia, não é similar à da matemática, pois aquela possui uma medida, um metron, que é a sensação do corpo humano; pelo que pode cometer erros. Contudo, o autor elogia os médicos que cometem o mínimo de erros.

Vegetti (1995, p.29-40) afirma que Platão se está distanciando do tratado Da medicina antiga e se aproximando do conceito de medicina de Trasímaco e do tratado Da arte. Mesquita (2011, p.41-60) pensa que a medicina hipocrática representa uma vitória sobre Trasímaco. Contudo, se Sócrates aceita a premissa de Trasímaco sobre a infalibilidade da medicina, Sócrates também é vencido. Mas parece-me que o objetivo que Platão tem em vista não é dizer se o médico erra ou não. Sócrates está mais testando suas teses do que afirmando categoricamente algo. Exemplificando, Sócrates quer provar que mesmo partindo do pressuposto que a ciência erra ou da afirmação contrária, a conclusão será inversa à tese inicial de Trasímaco (que a justiça é a conveniência do mais forte). Como foi dito, Platão está polemizando e abrindo caminhos para investigações que serão desenvolvidas nos livros seguintes. Isso não quer dizer que ele não esteja preocupado aqui em definir o que é a medicina e estabelecer uma analogia perfeita entre ela e a justiça. Estes temas abertos serão retomados ao longo da República.

\subsection{Medicina como analogon .}

Enquanto a craft-analogy é um instrumento de refutação socrática no debate contra os falsos saberes, onde são usados os parâmetros das technai gregas, o analogon é um tipo de

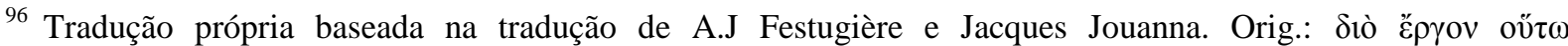

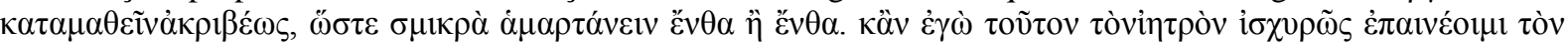

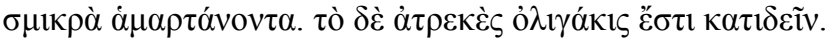


argumentação em que duas imagens aparecem tratadas como mutuamente similares em certos aspectos; e o que foi constatado como verdade em uma delas deve também ser considerado como verdade para a outra. Ele pode ser utilizado para polemizar, mas também possui uma alta potencialidade conceitual. Um exemplo de analogon é a comparação que Sócrates faz entre o indivíduo e a cidade: se é verdade que o indivíduo adoece, isso também vale para a cidade.

\subsubsection{O desenvolvimento do analogon no Livro II.}

O Livro I não termina com uma aporia formal ${ }^{97}$. Embora o livro termine com um acordo comum entre Sócrates e Trasímaco de que os justos são felizes e os injustos não, esse consenso é fictício. Trasímaco abandona a discussão quando os dois irmãos de Platão, Glauco e Adimanto, entram na discussão (no iníciodo Livro II), declarando que Sócrates não os convenceu sobre o fato de que o justo é melhor que o injusto (357a-b).

Glauco era um jovem naturalmente de origem nobre e de coragem (368a, 357a), dotado de um thymos guerreiro, que junto com seu irmão Adimanto lutou bravamente na batalha de Mégara. Não se privara do gosto pela cultura (548d-e), instruído em gimnastike e mousike $(398 \mathrm{e})^{98}$. Ele não fazia parte da natureza "timocrática" da cidade, pelo contrário, pertencia à melhor parte da aristocracia ateniense e se constituía ótimo defensor, phylax, da cidade melhor. Glauco também é o adversário mais implacável da fraqueza argumentativa de Sócrates (VEGETTI, 1998, p.151-172) talvez por sua aguda capacidade de raciocínio (365a) e estilo intelectual claramente "trasimaqueano". Adimanto, seu irmão, era próximo de Sócrates e estava presente no seu julgamento (Ap. 34a). O seu papel no diálogo não é tão incisivo quanto o de Glauco. Porém sua argumentação carrega uma bagagem cultural centralizada nos problemas religiosos e morais do século de Platão (VEGETTI, p.221-232).

$\mathrm{O}$ argumento de Glauco especifica que existem três tipos de bens: os que se desejam por si mesmo; os que se desejam, quer por si mesmo, quer pelas vantagens que nos dão; os que se desejam somente pelas vantagens que nos dão. Ele indaga onde se encontra a justiça nestes três tipos de bens. Sócrates defende que está no segundo tipo, Glauco diz que a opinião

\footnotetext{
${ }^{97}$ Usando a expressão de Schofield (2008, p.203). A aporia formal se diferencia da aporia de alguns diálogos como o Hipias Menor, onde ele permanece inconcluso.

${ }^{98}$ Sendo que por música devemos entender "todo domínio das Musas: não somente dança, lírica, épica e música instrumental, mas também a leitura, escritura, aritmética, geometria, história, astronomia” (NAILS, 2011, p.18).
} 
comum defende que está no terceiro $(357 \mathrm{a}-358 \mathrm{a})$. Ele responde a Sócrates afirmando que a origem e a essência da justiça é ocupar o lugar entre o maior bem (cometer a injustiça sem ser punido) e o maior mal (sofrer a injustiça quando se é incapaz de vingar). Ele continua dizendo que ninguém é justo voluntariamente (359b-360e), mas por sim coerção, e exemplifica com o famoso anel de Giges. Ele conclui pedindo desculpas pela rudeza, pois não é ele quem fala, antes os que colocam a justiça acima da injustiça (361e).

Adimanto intervém dizendo que o que se busca não é ser justo, mas sim a reputação de justo (362e-363b). A opinião dos poetas e da maioria reforça a convicção de que conquistar a justiça é uma tarefa árdua e conquistar a injustiça é fácil e agradável. Por isso, Sócrates deve explicar de forma mais clara qual é o efeito da justiça e da injustiça na vida do homem.

Em resposta aos dois irmãos, Sócrates reconhece que a investigação não era fácil. Assim, ele propõe um analogon entre a investigação da justiça e alguém que possui uma visão fraca (368d): por não enxergar as letras ao longe, devia notar que elas existem em toda parte de forma ampliada:

Portanto, talvez exista uma justiça numa escala mais ampla, e mais fácil de apreender. Se quiserdes então, investigaremos primeiro qual a sua natureza nas cidades. Quando tivermos feito essa indagação, executá-la-emos em relação ao indivíduo, observando a semelhança com o maior na forma do menor. $(R .368 \mathrm{e}-369 \mathrm{a})^{99}$

Sócrates conduz a investigação através de um analogon (isos): primeiro descobrir o que é justiça na cidade (en tais polesi); depois aplicá-la em cada um (en heni hekasto); observando a semelhança (homoioteta) do maior (meizonos) e do menor (elattonos). Segundo Adam (1902, p.91-2), neste trecho encontra-se o método que Sócrates irá perseguir na República (com exceção dos livros V-VII e X), e que, nos sucessivos estágios da exposição, ele irá nos lembrar dele constantemente ${ }^{100}$.

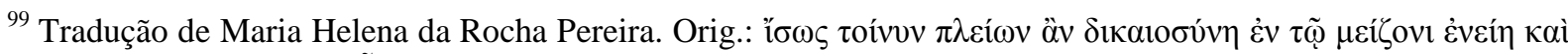

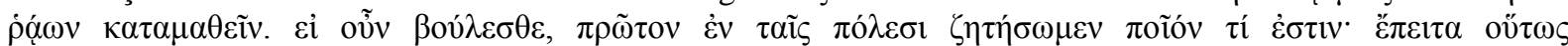

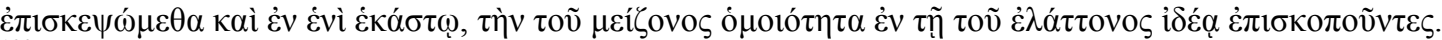

${ }^{100}$ Cf. R. 371e, 372e, 376c-d, 392c, 420b-c, 427d, 434d, 472b, 545b, 577c.
} 
A investigação socrática encontra vários paralelos na literatura grega antiga. Existiam noções vitalistas que viam o cosmos como um organismo vivo. Esta noção de vitalismo está presente no Regime (1. 10), onde o autor hipocrático resume toda sua teoria cosmológica e embriológica dizendo que o que está dentro do corpo humano é uma imitação do universo ${ }^{101}$ (apomimesis tou holou): o pequeno de acordo com o grande e o grande com o pequeno ${ }^{102}$. As teorias cosmológicas também eram ligadas com certo tipo de imagem política e social, o que pode ser notado nos fragmentos de Anaximandro, Empédocles e Heráclito ${ }^{103}$. Também, podemos constatar que os deuses são concebidos antropomorficamente: as noções de leis, direitos, obrigações mútuas são aplicadas a eles da mesma forma (LLOYD, 1966, 210).

Conforme os estudos de Lanza (1979, p.113-125), os médicos não criaram um léxico, mas se valeram de metáforas oriundas da agricultura, da arte bélica, da religião e da política ${ }^{104}$. Então, as noções na cosmologia grega foram influenciadas e influenciaram o pensamento político e biológico ${ }^{105}$; e, consequentemente, também não faltaram interações entre os campos da biologia e política, sobretudo entre o vocabulário médico e o judiciário ${ }^{106}$. O analogon de Sócrates também caminha por este rumo, ou seja, tentando agora estabelecer uma relação entre os tribunais e as clínicas.

\subsubsection{Aproximações entre medicina e justiça.}

O analogon que se desenvolve entre os "sistemas judiciários e médicos" se torna um fator de suma importância para compreender o papel da medicina na República. Este analogon parece não ser exclusivo da República, pois ele lembra o Górgias (464b-c):

\footnotetext{
${ }^{101}$ Doutrina que ficou conhecida como macrocosmo e microcosmo.

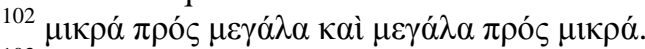

${ }^{103}$ Para uma análise detalhada de todas estas imagens sociais e políticas na cosmologia, ver Lloyd (1966, p.210232).

${ }^{104}$ Como por exemplo, katharsis (purgação), epipipto (cair sobre, atacar), haliskomai (ser preso), agrioumai (agravar-se). Ver também o emprego do verbo stasiazein no tratado dos Ventos (7) e sua relação com a República 556e e Tucídides (II, 47-53; III, 81-84). Ver também Desclos (2003, p.113-120).

${ }^{105}$ Desclos (2013, p.201-234) nota que o espaço físico é conatural ao espaço corporal. Disto decorre que os termos que servem para descrever a topografia de um também servem para descrever o outro.

106 Desclos (2003, p.87-120) e também Vegetti (2008, p.345-64) notam semelhanças na busca por uma causalidade (aitia) em ambos os escritos. Também destacam o uso do vocabulário jurídico nos escritos hipocráticos.
} 
Afirmo que há duas artes: em relação à alma, eu a chamo de política, ao passo que, em relação ao corpo, não posso chamá-la igualmente por um só nome, no entanto, visto que há um único cuidado para com o corpo, duas partes dele distingo, a ginástica e a medicina; quanto à política, em contraposição à ginástica há a legislação, enquanto a justiça é a contraparte da medicina. Cada par possui algo em comum, por concernir à mesma coisa, a medicina e à ginástica de um lado, e a justiça e a legislação, de outro, embora haja algo em que se difira. ${ }^{107}$

Pode-se representar o analogon do Górgias da seguinte forma:

\begin{tabular}{|c|c|c|}
\hline Técnicas da alma & $\begin{array}{c}\text { Legislação } \\
\text { (nomothetike })\end{array}$ & $\begin{array}{c}\text { Justiça } \\
\text { (dikaiosyne) }\end{array}$ \\
\hline Técnicas do corpo & Ginástica & Medicina \\
(gymnastike) & (iatrike $)$ \\
\hline $\begin{array}{c}\text { Imagens das técnicas da } \\
\text { alma }\end{array}$ & Sofísitca \\
Imagens das técnicas do \\
corpo
\end{tabular}

Sócrates polemiza com Górgias fazendo esta comparação entre as técnicas da alma e do corpo, sendo que a legislação está para a ginástica assim como a medicina está para justiça. Ele continua dizendo que a bajulação (kolakeia), que não é uma techne, se infiltrou no corpo e na alma simulando ser cada uma das coisas acima, originando assim dois pares: a cosmética e a culinária que correspondem à sofística e à retórica.

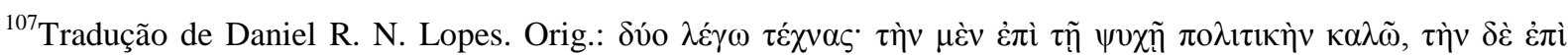

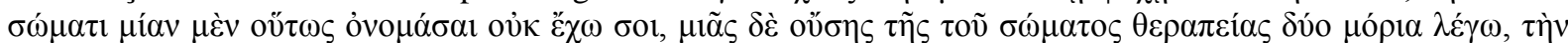

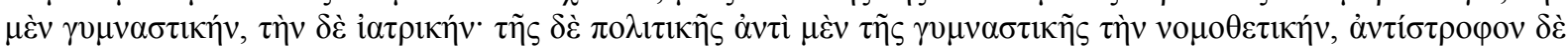

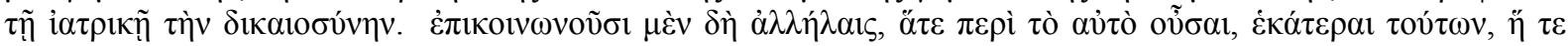

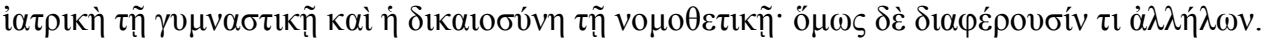


A diferença entre o analogon do Górgias e da República está na equiparação da ginástica à música e não (mais) à legislação ${ }^{108}$, e do sistema de saúde (não mais a medicina) ao sistema judiciário. Também não aparece o elemento de simulacro, ou seja, a bajulação. Acreditamos que esta diferença se deve ao contexto específico do Górgias, ou seja, tratar destes assuntos no âmbito da crítica à retórica.

O analogon do Górgias parece ser uma resposta de Platão a Isócrates, que nas Antidosis (15. 180-185) fez uma comparação semelhante. Isócrates afirma que todo homem é composto de corpo e alma, e que a alma, por ser mais excelsa, deve deliberar, enquanto que o corpo deve executar o que foi decidido pela alma (15. 180). Tanto para o corpo como para a alma foram inventadas técnicas: a ginástica para o primeiro e a filosofia para o segundo (15. 181). Assim como na ginástica, os professores de filosofia ensinam seus discípulos todos os procedimentos do discurso, para que se tornem oradores capazes ${ }^{109}$.

Voltando à passagem da República, Sócrates não tem a preocupação de refutar, mas sim de diagnosticar e tratar uma doença social. A polis está enferma, inflamada (phlegmainousan) entregue ao desregramento, amante da variedade dos pratos Sicilianos, das jovens de Corinto e dos doces áticos. De acordo com Sócrates, esta "variedade produz a licença, aqui, a doença; ao passo que a simplicidade na música gera a temperança na alma, e a ginástica, a saúde no corpo?” (404e) ${ }^{110}$

O analogon da República pode ser representado da seguinte forma:

\begin{tabular}{|c|c|c|}
\hline Regime & $\begin{array}{c}\text { Simplicidade } \\
\text { na música }\end{array}$ & $\begin{array}{c}\text { Simplicidade } \\
\text { na ginástica }\end{array}$ \\
\hline Gera no Indivíduo & Temperança na alma & Saúde no corpo \\
\hline Gera na Cidade & Não aumentar os tribunais & Não aumentar as clínicas \\
\hline
\end{tabular}

$\overline{108}$ Como nota Jaeger, (2001, p.796).

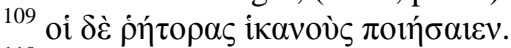

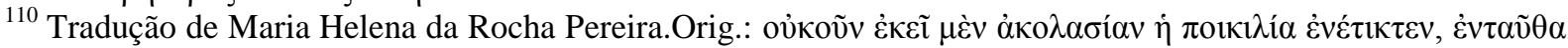

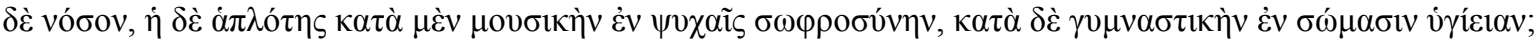


Platão não foi o único que fez um diagnóstico da cidade. Era comum usar metáforas da medicina e da política ${ }^{111}$ na literatura "pré-platônica", e talvez o primeiro diagnóstico da cidade tenha sido feito por Tucídides ${ }^{112}$. No discurso de Péricles (2. 62), lemos que a política imperialista de Atenas criou uma cidade tirana. Este imperialismo levou a uma colisão com Esparta, provocando um conflito civil, uma stasis em Atenas. A Guerra do Peloponeso foi um mestre violento (biaios didaskalos, 3.82). Logo veio a peste (2.53) e com ela uma decadência moral: "todos resolveram gozar o mais depressa possível todos os prazeres que a existência ainda pudesse proporcionar, e assim satisfaziam os seus caprichos, vendo que suas vidas e riquezas eram efêmeras" ${ }^{\prime 13}$. Segundo Tucídides, a peste trouxe conseqüências à vida moral e religiosa, instaurando uma anarquia e devassidão em Atenas: “o temor dos deuses e as leis dos homens já não detinham ninguém, pois vendo que todos estavam morrendo da mesma forma, as pessoas passaram a pensar que impiedade e piedade eram a mesma coisa"114. Nestes momentos de crise e tensão, descobre-se uma "natureza necessária" do homem (5. 105), a qual é dominada por um instinto de pleonexia, o desejo de sempre ter mais.

O diagnóstico de Platão é muito mais drástico, mas o seu prognóstico é mais otimista que o de Tucídides. A cidade estava doente, a doença infectou até mesmo o sistema de saúde. Os médicos que deveriam cuidar da cidade estavam contaminados. Era necessário um médico na cidade que pudesse curá-la. Este médico é o filósofo, mas para que os conceitos de médico, saúde e medicina fossem apropriados para política, era necessário traçar bem os limites da analogia. Platão condena e critica a medicina de seu tempo, para depois construir uma base conceitual do que deve ser a medicina e a saúde.

\section{CRÍTICA À MEDICINA: NOVAS DOENÇAS, NOVAS TERAPIAS, NOVOS DOENTES.}

\footnotetext{
${ }^{111}$ Contra Lombard (1999, p. 29, 56-57).

112 Para uma comparação entre Tucídides e os escritos hipocráticos ver Desclos (2003, p.87-120).

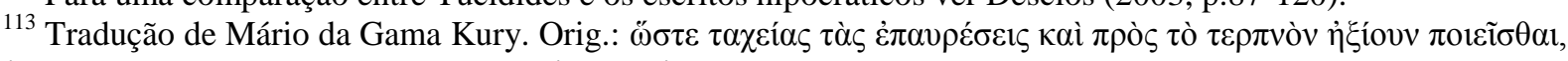

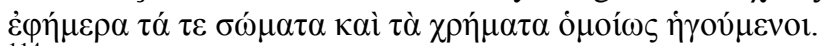

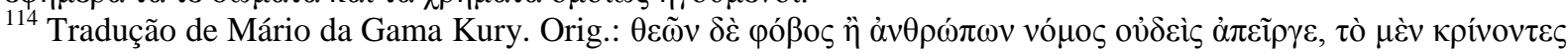

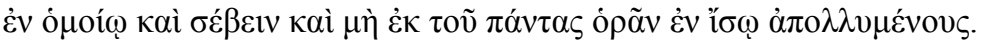


No Livro II, Sócrates propõe a Adimanto (369c) que se construa uma cidade no discurso (to $\log o$ ). A cidade nasce "no fato de cada um de nós não ser autossuficiente, mas sim necessitado de muita coisa" $(369 b)^{115}$. A necessidade reúne em um mesmo local um grande número de associados e auxiliares (369e-370a), e cada um deve cumprir a sua própria função (hautou prattein) ${ }^{116}$. Em seguida (372c-d), Sócrates descreve um regime de vida simples e uma alimentação frugal ${ }^{117}$ dos cidadãos.

Depois desta descrição, Glauco acusa Sócrates de estar projetando uma cidade de $\operatorname{porcos}^{118}$ (372d). Glauco propõe que os homens devem deitar em camas, serem servidos com manjares e com doces "atualmente conhecidos", pelo que Sócrates passa a descrever uma cidade não mais sã (hygies), mas uma cidade inflamada (phlegmainousan) ${ }^{119}$. Multiplicam-se os caçadores, imitadores, os fabricantes de atavios femininos, as cortesãs, os dançarinos, atores, cozinheiros, açougueiros, porqueiros, etc. Agora "sentiremos muito mais a necessidade de médicos, levando esta vida, do que anteriormente?"120 (373d). Sócrates propõe, então, uma educação da cidade, um projeto de terapia da segunda cidade, a cidade doente. Este projeto começa em uma educação a fim de delinear (como se contássemos um mito 376d) o modelo

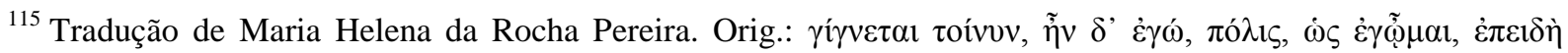

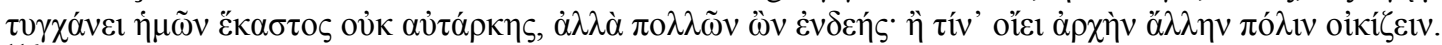

${ }^{116}$ Karl Marx (1996, p.480) afirma que este ideal da divisão do trabalho começou no livro II da República e que foi, para Platão, o fundamento do Estado. Dizer que a expressão platônica autou prattein significa divisão do trabalho é um anacronismo na medida em que implica uma representação da profissão em referência à produção em geral (CAMPESE, 1998, p.285-306). Para a interpretação "socialista de Platão ver Vegetti, 2010, p.67-110,

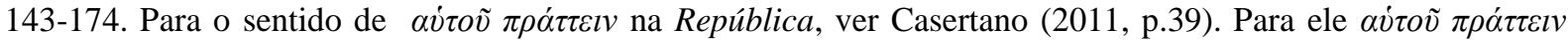
significava várias coisas: importar-se apenas com os seus interesses, ocupar-se das coisas que se sabe fazer, cumprir as obras para as quais se está disposto com base na própria natureza. Para a gênese da cidade, ver também Vegetti, (2011, p.38-65).

${ }^{117}$ A posteridade legou uma anedota sobre a comida frugal na Academia de Platão. Segundo Plutarco, no tratado sobre Conselhos para conservar a saúde, (127a), Timóteo, um general ateniense, filho de Cónon e discípulo de Isócrates participou de um banquete filosófico e notou que os que comeram com Platão amanheceram dispostos e leves. Esta anedota está de acordo com o pensamento antigo em que a alimentação pode mudar os temperamentos. Galeno (Quod animi, 1) apresenta uma prova que faculdades da alma seguem as do corpo. Segundo ele a alma é embelezada e possui um bom temperamento através dos alimentos e das bebidas. Seguindo uma dieta assim, a alma chega à excelência como os discípulos de Platão e Pitágoras chegaram.

${ }^{118}$ Adam (1902, p.100) não aceita que a expressão "cidade de porcos" seria uma referência de alimentação comum de Antístenes. Adam não vê uma base sólida para esta teoria, mesmo porque segundo ele a proton polis não é a "cidade ideal" de Platão.

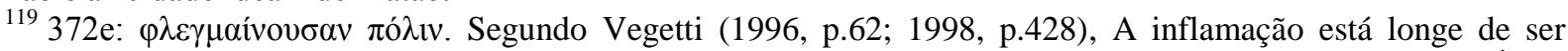
somente uma metáfora. Ela é amplamente discutida no Regime (I, 35), no Lugares no homem (13, 29), na Água, ares e lugares e no Regime das doenças agudas 37. Vegetti afirma que a inflamação tinha como sua principal

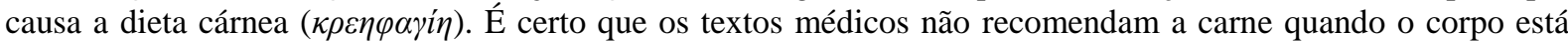
com inflamação, mas isso não seria uma evidência que Platão seria um adepto do regime dos pitagóricos ou um vegetariano.

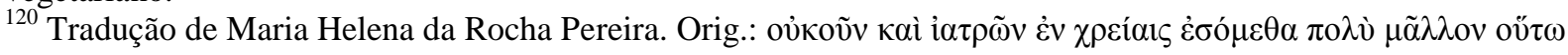

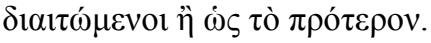


da terceira cidade, "sana come la prima, pur accettando l'inevitabile complessità di ruoli e figure sociali proprie della seconda" (VEGETTI, 2011, p.47)

Já neste programa de educação da cidade, Sócrates retorna o assunto (404a), perguntando qual seria o melhor regime para os atletas que se preparam para competição. Segundo ele os atletas deveriam buscar um regime mais fino e fugir de uma dieta sonolenta e perigosa para saúde como era costume na época. Os guardiões, por sua vez, deveriam aprender com Homero (404c) comendo carnes cozidas, em vez de assadas, e sem condimentos. Além disso, deveriam abster-se:

a) da mesa de Siracusa e dos pratos Sicilianos, notoriamente luxuosos. A mesa de Siracusa (syrakosian trapezan) é possivelmente proverbial; seria uma referência à glutonaria deste local descrita na Carta VII (326b);

b) das jovens de Corinto. Estas jovens (korinthian koren) fazem referência às cortesãs daquele local. A palavra utilizada não é hetaira, nem philen, palavra mais refinada, mas koren cujo significado é dúbio: pode significar tanto jovem esposa, boneca, menina dos olhos, concubina.

c) das delícias da pâtisserie Ática. Por fim, a fama das delícias Áticas, principalmente de Atenas era devida tanto a sua variedade como a sua grandiosidade (ADAM, 1902, p.173).

Este regime deu origem às novas doenças que, por sua vez, trouxeram novas terapias e deram origem a um novo tipo de doente. Apesar de esta digressão estar inserida no contexto do regime dos guardiões ${ }^{121}$, a crítica se estende para todo um sistema de saúde da Atenas histórica. Platão tem em vista o regime dos guardiões, mas ele confronta este regime de homens guerreiros e fortes com um regime languescente de pessoas "dependentes" de tratamento. Platão não está ironizando ou defendendo a medicina de Homero, como pensa Strauss (2014, p.88-92). Veremos que ele está apontando à medicina de Asclépio como uma medicina de homens sãos, que muito difere da sua atual medicina.

\footnotetext{
${ }^{121}$ Casertano (2011, p.46) diz que há controvérsias se plano educativo diz respeito só aos guardiões (a classe dos guerreiros e dos filósofos) ou ela se estende a todas as classes.
} 


\subsection{Novas doenças: mais tribunais e mais médicos.}

Em 405a, Platão irá dizer que a necessidade de mais médicos na cidade é vergonhosa $^{122}$. Os médicos são honrados na cidade e existe uma proliferação de clínicas $\left(\right.$ iatreia $\left.^{123}\right)$ devido ao estilo de vida sedentário e ao regime de vida não saudável ${ }^{124}$ (405d). Isso causa espanto a Platão, principalmente pelo número crescente de homens livres que passam a se interessar pela medicina (405a). Também existe uma crescente busca pelos tribunais. O progresso que os estadistas trouxeram (exaltado no Prometeu de Ésquilo e no tratado hipocrático Da medicina antiga) não parece ser um verdadeiro progresso aos olhos de Platão.

\subsubsection{Analogon: multiplicação de tribunais.}

Platão afirma que este aumento de "tribunais" e "hospitais" não é sinal de uma evolução da civilização, mas um forte indício (tekmerion) de vício e de uma vergonhosa educação na cidade $^{125}$. A cidade não educada tem necessidade da proliferação destas duas instituições.

Mas quando a licenciosidade e as doenças se multiplicarem em uma cidade, não abrirão muitos tribunais e clínicas, e exaltarão os peritos na lei e os médicos, quando muitos homens livres se lhe ocuparem seriamente?

Não pode ser de outra forma.

\footnotetext{
${ }^{122}$ Averróis (2011, p.31) diz que a necessidade de médicos e tribunais tem origem no afastamento da utilização do que era natural, não só da alimentação, mas da música, dos exercícios, etc.

123 iatreia (ADAM, 102, p.173) era tanto o dispensário da cirurgia como o local da consulta. Em algumas iatreia os pacientes eram internados e tratados pelos médicos.

${ }^{124}$ Porfírio, no Sobre abstinência, (1. 47), liga a necessidade de médicos à multiplicação das enfermidades com a dieta cárnea.

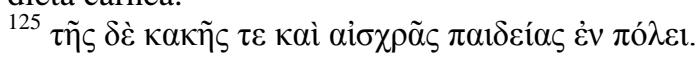


Mas qual o maior indício do vício e da vergonhosa educação na cidade do que a necessidade de médicos e juízes eminentes, não só para o homem do vulgo e os artesãos, mas ainda para os que se jactam de ter recebido uma educação liberal? Não pensas que é um vergonhoso indicio e necessidade de educação, alguém ser forçado a recorrer uma justiça alheia, converter os outros em juízes e senhores, pela incapacidade de ter uma própria? $(405 a)^{126}$

O tribunal é o sinal da obrigação de recorrer a uma justiça que não é a sua, mas uma justiça pedida de empréstimo a outrem (par'allon). É vergonhoso muitos passarem a maior parte da vida acusando ou sendo acusados nos tribunais; mas mais ainda que estes cidadãos sintam orgulho na sua capacidade de fazer injustiça, recorrendo a todo tipo de mecanismos para "contornar" as disposições gerais, contratando peritos na lei (dikanike ${ }^{127}$ ) para os defenderem, somente com o intuito de fugir da justiça. Eles ignoram que o mais belo e melhor é preparar sua vida, organizando-a sem a necessidade de um juiz sonolento ${ }^{128}$. Em suma, se todos os homens fossem justos e assim vivessem, não haveria necessidade de tribunais.

Esta crítica aos tribunais lembra as comédias de Aristófanes, como por exemplo, As Vespas, que satiriza o sistema ateniense de tribunais. Naquela época os tribunais proporcionavam um meio de subsistência para a maior parte dos cidadãos pagando três óbolos por dia pela presença nas sessões. Bdeliclêon tenta curar o pai, Filoclêon, do seu fanatismo pelas seções judiciárias, prendendo-o em casa. Filoclêon faz um encômio à figura do juiz (vv. 550-60) dizendo que este homem é temido, escoltado por homens importantes, paparicado por aqueles que praticam o peculato contra o erário e honrado pelo sistema. Bdeliclêon, por sua vez, replica que os jurados são meros instrumentos dos governantes, que desviam em benefício próprio a arrecadação destinada para alimentar os necessitados. Segundo ele o

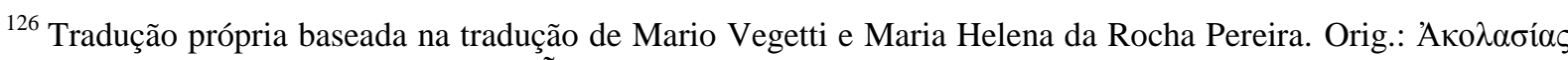

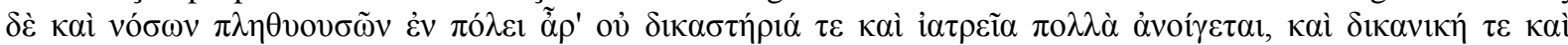

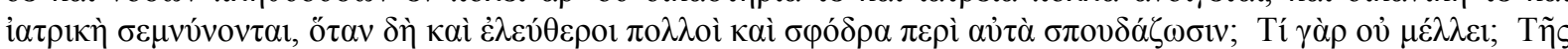

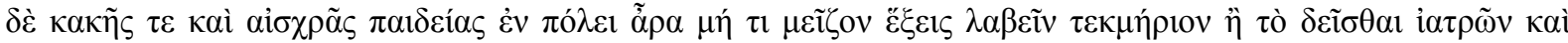

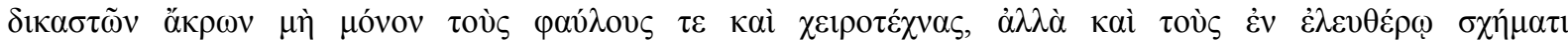

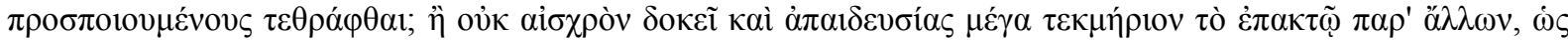

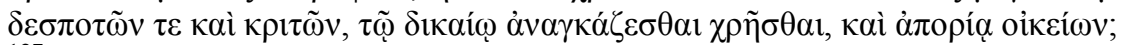

${ }^{127}$ Adam (1902, p.173) nota que Platão escolhe deliberadamente a palavra menos reputada (dikanike em vez de dikanistike) para reforçar o sentido pejorativo daquele tipo de conduta.

${ }^{128}$ Possível alusão à morosidade do sistema judiciário.
} 
honorário dos juízes estava pesado para cidade, pois nunca houve tantos gastos deste tipo por aqui (vv. 660-5).

Em oura comédia, As Nuvens (vv. 112-8), o alvo é Sócrates. O personagem Estrepsíades busca um meio de escapar das dívidas enviando o filho para estudar retórica na casa de Sócrates. Com Sócrates, o seu filho irá estudar um argumento "Inferior", que consegue vencer defendendo as causas mais injustas. Aprendendo este argumento injusto, não seria necessário pagar mais nenhuma dívida. Platão possivelmente tinha em mente responder a Aristófanes que Sócrates não ensinava a injustiça ${ }^{129}$. Nota-se, contudo, que Aristófanes, Platão e Tucídides (3. 82) testemunharam, cada um à sua maneira, o apego exagerado pelos tribunais na Atenas dos séculos V e IV. Igualmente exagerado é o apego às clínicas e aos médicos.

\subsubsection{Multiplicação de clínicas e novas doenças.}

A frouxidão moral de um povo pode atrair novas doenças. Contudo, o que Platão está dizendo não é que todas as doenças são de origem moral, pois ele deixa claro que também existem as doenças sazonais e ferimentos que exigem cuidados médicos. O problema é que se operou uma ruptura no quadro nosológico da medicina tradicional que deveria existir para cuidar dos ferimentos e das doenças sazonais. Agora a cidade se vê diante de doenças que são causadas pelo abuso dos prazeres alimentares e do descomedimento, o que obriga os médicos a darem nomes a estas novas doenças.

Platão não nega a necessidade de médicos, nem do tratamento. Ele faz alusão aos ferimentos, que estará muito provavelmente relacionada com acidentes de trabalho ou até mesmo com treinos, combates e guerras. Ele fala também das doenças sazonais que são as que nascem e morrem ao ritmo da estação (Nat.Hom. 8).

Píndaro ( $P .3$ 47-50) havia classificado as doenças sazonais dividindo-as em verão e inverno; porém a maioria dos escritos médicos dividia em quatro: verão, inverno, outono e primavera. No terceiro livro dos Aforismos, 20-23, pode-se ler uma descrição minuciosa das

\footnotetext{
${ }^{129}$ Strauss (1987, p.169) cita uma série de passagens da República que encontram paralelos com a comédia de Aristófanes, não obstante a maioria das aproximações seja tênue. O objetivo central da República não era responder à Aristófanes.
} 
enfermidades sazonais divididas entre as quatro estações. Esta lista cita epilepsia, melancolias, coriza ${ }^{130}$, tosse, vômitos, vertigens, etc. O tratado hipocrático Ares, águas e lugares discorre sobre uma "medicina meteorológica": partindo do pressuposto que o homem é parte do cosmos, o autor tenta explicar como o clima e as estações influenciam a saúde dos indivíduos (Aër1-2) e das cidades.

Além das conseqüências sociais, Platão ressalta que a doença provocada pela intemperança trouxe conseqüências lingüísticas. Ele afirma (405c-d) que esta novidade lingüística foi trazida pelos nobres asclepíades (kompsous asklepiadas).

Mas não, disse, isto é mais vergonhoso ainda.

Ter necessidade da medicina, disse eu, não pela ferida ou por causa das doenças que vêm a cada ano, mas pela preguiça e a dieta que descrevemos, fica-se cheio de fluxo e de ventosidades, constrangendo os nobres Asclepíades a dar a estas doenças as designações "flatulências" e "catarros", não parece vergonhoso?

Sim, disse ele, na verdade estes nomes destas doenças são novos e absurdos. $^{131}$

Segundo Adam (1902, p.175), os adjetivos kompsoi e charientes são geralmente aplicados aos médicos mais avançados e especializados. Liddell-Scott (1996) nota que em Platão a palavra kompsos adquire um sentido de precisão técnica, porém com uma tonalidade irônica, geralmente referindo algum sofista ou argumento sofístico. No Crátilo (429d),

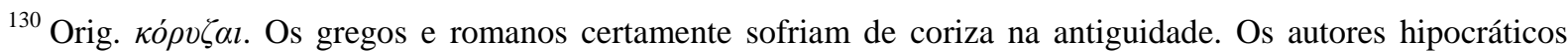
notaram que a coriza se manifesta ao mesmo tempo que certos problemas, em particular nos pulmões (Prog.14, Pren.Cos, 393). Grmek (1983, p.475-6) afirma que estas corizas sintomáticas não são gripes no sentido atual. A verdadeira "gripe cerebral" descrita no Da medicina antiga, (18), é um dos fenômenos que os médicos da antiguidade utilizavam como modelo para explicar a noção de crise.

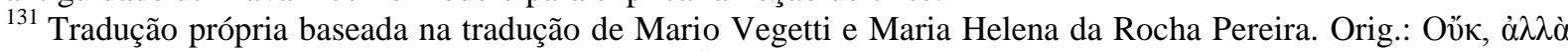

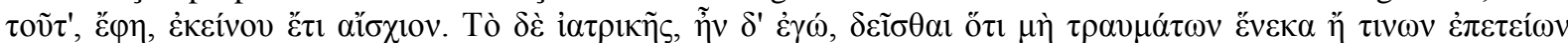

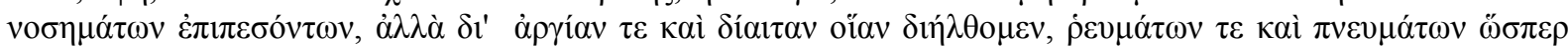

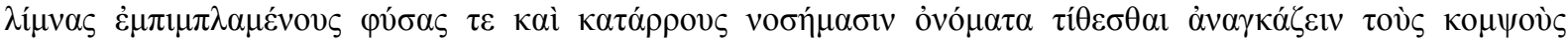

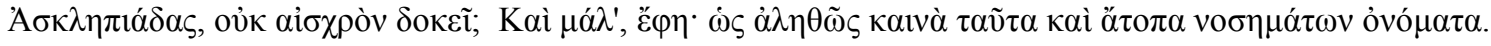


Sócrates diz que os argumentos de Crátilo são "excessivamente engenhosos (kompsoi) para ele" naquela idade em que se encontrava. No Teeteto (171a), Sócrates diz que o argumento de Protágoras “envolve um traço de enorme requinte (kompsótaton)". Vegetti (1996, p.65-6) defende que o uso aqui é irônico e polêmico, pois o termo também se traduz como "refinados Asclepíades", uma possível crítica a Heródico de Selimbra, um sofista de notável importância (Prt. 316e).

Os "nobres" asclepíades ou a refinada corporação de médicos agora têm que encontrar ou criar novas designações para as doenças. O Corpus hippocraticum apresenta uma extrema riqueza de termos nosológicos. Esta terminologia não é uma criação dos médicos hipocráticos, mas sim uma herança dos antigos "mestres da verdade" (poetas, historiadores, etc ${ }^{132}$ ). Os vocábulos das partes do corpo humano são homéricos, inclusive toda nomenclatura "anatômica" facial ${ }^{133}$. Constata-se, contudo, um esforço de síntese para superar a multiplicidade de doenças, organizando-as em grandes categorias. Essa primeira tentativa aparece em Píndaro (P. 3. 47-50). Dentro do Corpus Hippocraticum, além de um reagrupamento da nomenclatura nosológica dos antigos ${ }^{134}$, há uma ressignificação de termos usados na poesia e o acréscimo de alguns prefixos, criando neologismos. A formação por composição normalmente se dava pelo acréscimo de um prefixo, como se pode ver nas Epidemias I e III. ${ }^{135}$

Os humores (reumaton) e vapores (pneumaton) estão respectivamente conectados com catarros (katarrous) e flatulências (physas). Estas doenças também aparecem no Corpus hippocraticum:

a) O catarro é visto atualmente como inflamação das membranas mucosas, especialmente das passagens do ar, junto com a produção do exsudato mucóide ${ }^{136}$. Nos escritos hipocráticos

\footnotetext{
${ }^{132}$ Cf. Jouanna (1992, p.220-2); Lloyd (2009, p. 1-41); Lanza (1979, p.112-125); van Brock (1961, p.1-6).

${ }^{133}$ Por exemplo, em Lanza (1979, p.112-125): Face (Prosopon), fronte (metopon), sobrancelha (ophryes), olho (ommata/ophthalmoi), nariz (ris), orelha (ota). Poucos vocábulos não são homéricos, tais como: lombo (psoa), tertículo (orchis), útero (meter/hysterai), uretra (oureter).

${ }^{134}$ Sobre a escrita do Corpus, ver Pigeaud (2009, p.27-52).

${ }^{135}$ Por exemplo, o prefixo $\tau \alpha \chi v-\tau \alpha \chi v \theta \alpha ́ v \alpha \tau o \varsigma$ (morte rápida), $\tau \alpha \chi v \varphi v \eta ́ \varsigma$ (crescimento rápido), $\tau \alpha \chi v ̃ \gamma \eta \rho \circ \varsigma$ (rápido envelhecimento).

${ }^{136}$ Para a história do catarro ver, Kiple ( 1993, p.635-37).
} 
katarroi era mais que corizaou catarro no nosso sentido moderno do termo: significava todo humor da cabeça que "flui para baixo". O catarro era ligado a três fatores ${ }^{137}$ :

i. Climáticos. O autor do Dos lugares do homem, (9-10), faz uma elaborada doutrina dos fluxos, (rooi). Segundo ele os fluxos estão etiologicamente relacionados com as mudanças sazonais, e com a ação do frio e do calor no corpo humano (Aër 3). A maioria deles desce da cabeça e admitem sete cavidades, os que escorrem pelo nariz, pelo ouvido, olhos, peito, medula, vértebras e quadril.

ii. Patológicos. A palavra katarroa é utilizada ${ }^{138}$ com o sentido de fluxo que podem sair de uma ferida; o autor hipocrático prescreve a unção da ferida com remédios umectantes para que o fluxo (ta katarroa) saía da ferida (Nat.Hom. 29). O catarro é relacionado também com o rheuma que desce do cérebro (Morb.Sacr. 6-13; Aër 3). Platão utiliza a palavra katarrous no Crátilo (440 b-d) com o sentido nosológico de fluxo ilustrando a teoria de Heráclito; ele diz que as coisas fluem (rei) como potes que vazam ou como pessoas com doença de catarro (katarro nosountes), escorrendo e gotejando $^{139}$ o tempo todo.

iii. Estilo de vida. No Regime (3. 70), o autor relata que quando os alimentos são ingeridos em grande quantidade e os exercícios são poucos, então se produz catarro.

b) A palavra physa, por sua vez, não é nova, pois já aparece na Ilíada(18. 372), e em Heródoto (1. 68) com o sentido de foles ${ }^{140}$. Contudo, nos escritos médicos (Loc.Hom.45; VM 10 Acut. 23, 27) a palavra physa significa ventos, respiração, ventos no corpo, flatos. O Anonymus Londinensis (V 5 - VII 40) relata que o cerne da doutrina nosológica de Hipócrates se baseava nos phusai como sendo a causa das doenças ${ }^{141}$. O tratado Dos ventos (Peri physon) é um discurso sofístico ${ }^{142}$, escrito e dedicado para uma exposição oral ${ }^{143}$, onde o autor tenta

\footnotetext{
${ }^{137}$ Ver Index Hippocraticum (1986, p.430).

${ }^{138}$ Se o texto do manuscrito estiver correto.

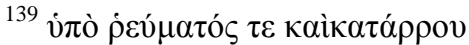

${ }^{140}$ Fole de ferreiro ou fole de forja é uma ferramenta usada pelos ferreiros para atiçar o fogo na hora da forja de metais. É composto de uma sanfona de pele entre duas peças de madeira com cabo, que quando aproximadas expulsa o ar para fora da sanfona. No caso da Ilíada, aparece no plural para indicar as foles de Hefesto.

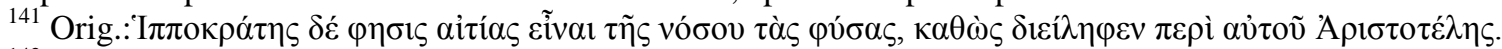

142 Jones $(1923$, p.221) vê semelhanças entre o tratado e Diogenes de Apolônia, calculando assim a datação próxima de 430 aEN Nota também semelhanças entre a linguagem metafórica de Hípias (Prt 337c-338a) com o referido tratado. Gual (2008, p.129) nota que a linguagem do capítulo 3 está próxima do estilo de Górgias, pela repetição das palavras, a personificação de um ser incorpóreo e a antítese dupla.

${ }^{143}$ Quanto ao conteúdo, datação e autoria ver Jones(1923, p.221-25); Jouanna, (1992, p.562); Gual(2008, p.121130); Littré, (1839, VI, 88-9).
} 
demonstrar que as flatulências são a causa de todas as enfermidades. No capítulo 3, ele diferencia physai de aer, sendo que o primeiro é o pneuma no corpo e o segundo seria o pneuma fora do corpo. A tese de que o ar constitui um alimento está relacionada com a medicina dietética (VEGETTI, 1998, p.435) e, segundo o autor do tratado, se uma pessoa come ou bebe excessivamente, entra muito sopro também, o qual se transforma em flatulências. Estas physai são a causa dos rheumata orgânicos (Flat. 7). Outra obra que distingue as flatulências internas do ar externo é o Regime (2. 40), que também lida com o aparelho digestivo. A causa das flatulências é geralmente alimentar. Ela está relacionada com a ingestão de pães, biscoitos de cevada (Vict. 2. 40) e favas (Vict. 2. 45). ${ }^{144}$

Se Platão admitia os médicos na cidade para tratarem de doenças sazonais e ferimentos, então os catarros produzidos pelo clima não eram o alvo de seu ataque, mas sim os catarros e as flatulências que estavam relacionados com o modo de vida da cidade inflamada. Platão se apropria das ideias da medicina dietética para fazer este diagnóstico social. O mais absurdo (atopa) é que a vida desregrada da sociedade trouxe consequências "linguísticas", pois que os médicos se debruçaram em uma tarefa de dar nomes, de criar uma língua "especializada" para dar conta das novas doenças. De certa forma, por meio de novas doenças, a medicina "avançava".

Existe um nexo entre a patologia social e o desenvolvimento da medicina: a doença é um dos fatores que forjam o destino dos homens, afetam a economia, os movimentos demográficos e a moral. Grmek (1983, p. 141-2) nota a transformação social da Atenas do século VI, que era essencialmente agrícola, para uma urbanização através do artesanato e comércio. Depois da Guerra do Peloponeso, a saúde pública entrou em declínio, não apenas por causa da peste, mas também por muitos outros fatores: o abandono da vida rural e, por consequiência, o abandono da drenagem dos pântanos, a superpopulação urbana, a insuficiência de esgotos e inspeção sanitária. Além disso, deslocamento dos refugiados da guerra trouxe doenças gastrointestinais, malária, tifóide e tuberculose. Se valendo dos estudos da paleodemografia, Grmek (1983, p.157) afirma que a média de vida do ateniense passou de

\footnotetext{
${ }^{144}$ Contra Vegetti (1996, p.62,74). Ele acredita na relação do fluxo e das flatulências com a dieta cárnea. Porém o texto do Regime é bem específico quanto a este ponto, pois as flatulências são causadas não somente por carne, mas por ingestão de pães, biscoitos de cevada e pelas favas.
} 
45 anos na época clássica para 42,4 anos nos séculos IV e III aEN. Este crescimento da cidade era visto como progresso pelos atenienses. Platão não pode concordar com isso, por isso ele se volta contra a ideia de progresso a qualquer custo.

\subsubsection{Crítica ao progresso a qualquer custo.}

Pelas informações de que até agora dispomos, não podemos afirmar com certeza que Platão teve contato com o tratado Da medicina antiga. Segundo este tratado, a medicina é retratada como parte de um progresso humano, um desenvolvimento de um estágio onde todos viviam em um regime alimentar animal e selvagem que, caso se fosse seguido por muito tempo, eliminaria toda humanidade. Esta ideia de progresso no Da medicina Antiga encontra muitos pontos de contato com a Kulturgeschichte do século V. Tal conceito pode ser visto no mito de Protágoras (Prot. 320a - 323d), nas tragédias de Eurípedes (Supp. 201-213), no Prometeu de Ésquilo (Pr. 436-506), e até mesmo na Oração Fúnebre de Péricles descrita por Tucídides na História da Guerra do Peloponeso (2. 36) ${ }^{145}$. Contudo, o que chama a atenção de muitos leitores (DEMONT, 2013, p.2-10) do trecho é o paralelo com algumas afirmações de Sócrates na República.

A propósito da alimentação ( $R$. 372b) da cidade sã, Sócrates defende que a nutrição será à base dopreparo de "farinha de cevada e de trigo, cozendo esta e limitando-se a amassar aquela", fazendo magníficos bolos e pães sobre ramos ou folhas frescas. Deste modo, viverão em paz e saúde. Essa descrição se parece com o trecho do Da medicina antiga (3), mas apenas com uma diferença: o autor do tratado hipocrático diz que a alimentação primeva do homem era nociva. Além disso, a medicina não parou de avançar em sua parte heurística, chegando à medicina dietética que separa os alimentos do são e do enfermo $(V M 8)^{146}$.

Platão, ao contrário, vê a medicina dos seus dias como o sintoma de uma decadência. Segundo Mirko Grmek, a sociedade ateniense contemporânea a Platão testemunha um grande

\footnotetext{
${ }^{145}$ Segundo Pradeau (1997, p.37-51), Platão faz uma paródia no Menexeno, indicando que não se trata de um progresso, mas de uma decadência.

${ }^{146}$ Cf. van der $\operatorname{EIJK}(2005$, p.113).
} 
paradoxo em seu tempo: paralelamente ao seu desenvolvimento, a saúde dos gregos se deteriorava. $^{147}$

\subsection{Novas terapias: medicina de Asclépio versus Heródico.}

Platão, para confirmar que estas novas doenças (fluxos e flatulências) não existiam na época de Asclépio, cita uma passagem da Ilíada, onde os filhos de Asclépio não censuravam as práticas e os remédios que eram ingeridos durante a Guerra de Troia. O texto joga com as palavras "Asclépio", "filhos de Asclépio" e "asclepíades". Em sua crítica às práticas terapêuticas dos médicos gregos, Platão convoca Asclépio como paradigma da verdadeira medicina.

Platão se volta contra as técnicas de Heródico e constata que a medicina de seus dias está decadente. As novas práticas terapêuticas são "pedagogias da doença", onde o doente não quer mais se submeter à um tratamento doloroso que extraia a doença de uma vez por todas.

\subsubsection{As práticas terapêuticas na Ilíada: o tratamento de Macáon e de Eurípilo.}

Sócrates afirma que nem o pharmakon que uma mulher ministrou sobre Eurípilo, quando este estava ferido, nem o pharmakon de Pátroclo (405d-406a) foram censurados pelos filhos de Asclépio. O texto da Ilíada (11. 639-51) apresenta uma versão diferente: o remédio foi dado pela escrava de Nestor, Hecamede, a Macáon e não a Eurípilo:

\begin{tabular}{|c|c|}
\hline \multicolumn{1}{|c|}{ República $(405 \mathrm{~d}-406 \mathrm{a})$} & \multicolumn{1}{c|}{ Ilíada (11.639-51) } \\
\hline $\begin{array}{l}\text { Tais, eu disse, não existiam, penso, no } \\
\text { tempo de Asclépio. Eu o atribuo ao fato }\end{array}$ & $\begin{array}{l}\text { (..) ancila verte } \\
\text { vinho de Prâmnio e raspas de queijo caprino }\end{array}$ \\
\hline
\end{tabular}

${ }^{147}$ La médecine scientifique grecque se constitue au moment de la rupture de l'équilibre pathocénosique; parallèlement à son développement, la santé des Grecs se détériore. On peut y voir une sorte de paradoxe. (GRMEK, 1983, p.141) 


\begin{tabular}{|l|l|}
\hline que os seus filhos em Tróia, quando & ralado a bronze, e branca farinha; a provar \\
Eurípilo foi ferido e uma mulher lhe deu & da infusão os convida e aplaca a sede de ambos, \\
de beber do vinho Prâmnio polvilhando & agrura multiardente; com deleite os dois \\
sobre ele muita farinha de cevada e queijo & se põem a discorrer; e conversavam quando \\
ralado, o que parece ter propriedades & surge Pátroclo à porta, par-dos-deuses. Nestor \\
inflamatórias, não a censuraram e nem & $\begin{array}{l}\text { se ergue da sédia fúlgida ao vê-lo e na tenda } \\
\text { pela mão o introduz: de imediato o convida }\end{array}$ \\
reprovaram Pátroclo que o curava. & $\begin{array}{l}\text { a sentar-se. Mas Pátroclo lhe diz: "Gerênio, } \\
\text { Eão posso aceitar. Temo e respeito o irascível } \\
\text { por um homem naquela condição. }\end{array}$ \\
que me mandou aqui; quem trouxeste ferido \\
para a tenda, já o vejo com meus olhos: é o \\
bravo Macaone, líder-de-povos.
\end{tabular}

Esta passagem era conhecida por Platão, tanto que ele chega a citá-la no Íon (538c) conforme o original. Alguns ${ }^{150}$ poderiam levantar uma objeção explicando que Platão estava confuso ou que a sua versão da Ilíada era diferente da atual, mas o trecho no Íon não dá base para esta interpretação. Strauss (2014, p. 98-90) vê neste "deslize" de Platão uma indicação literária e irônica de que ele estaria criticando a medicina de Homero. Acreditamos como Vegetti (2008, p.125), que Platão opera aqui uma crase entre a cura de Macáon e de Eurípilo, e o tratamento de Hecamede e de Pátroclo.

\footnotetext{
${ }^{148}$ Tradução própria baseada na tradução de Mario Vegetti e Maria Helena da Rocha Pereira. Orig.:Oĩa, $\tilde{\eta} v \delta^{\prime}$

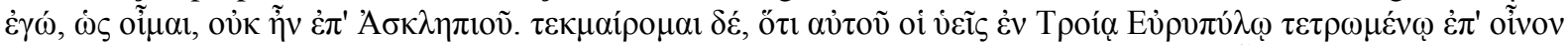

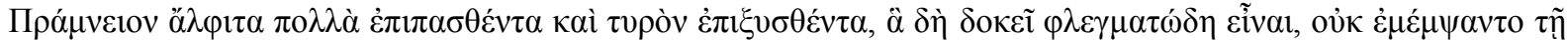

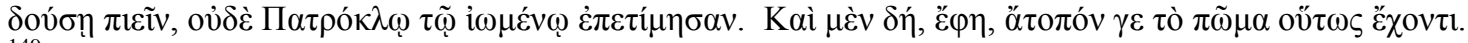

${ }^{149}$ Traduçãode Haroldo de Campos. Orig.: oüv

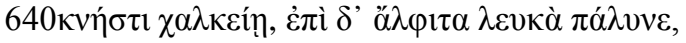

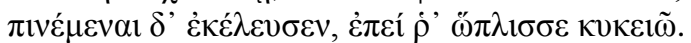

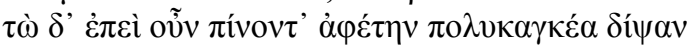

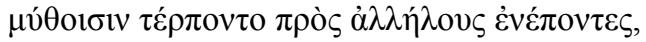

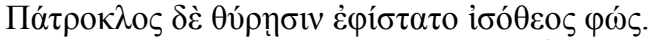

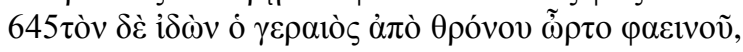

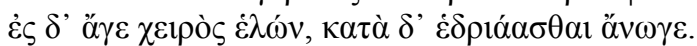

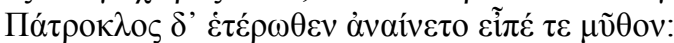

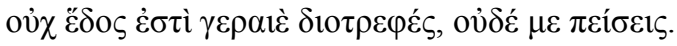

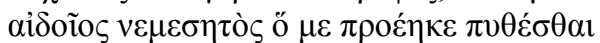

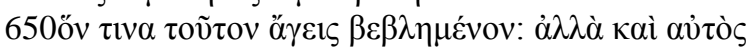

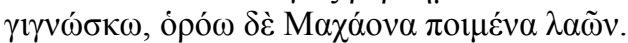
${ }^{150}$ Ver Adam (1902, p.177-8), Shorei (1937, p.272).
} 
O kykeon ${ }^{151}$ que Hecamede ministra a Macáon pode ser altamente nocivo ao paciente. No tratado Do regime nas enfermidades agudas (39), o autor adverte que, durante o tratamento das enfermidades agudas, a alimentação, a infusão e o kykeon são mais nocivos do que se o doente seguisse outra dieta. O kykeon de Hecamede era composto, segundo Platão, de vinho Prâmnio ${ }^{152}$ polvilhado com farinha de cevada e queijo ralado, e possuía um efeito inflamatório para um homem "naquele estado" (406a). O tratamento de Eurípilo por Pátroclo é descrito na Ilíada (11. 822-48; 15. 390-5). Na primeira passagem Pátroclo retira o dardo, lava a ferida com água morna e aplica um remédio; na segunda, em visita à tenda de Eurípilo, entretém-no com conversas e aplica um remédio doloroso e funesto.

Nas três narrativas podemos notar práticas "médicas" durante a Guerra de Troia: duas aplicações de um remédio "perigoso" e um processo "cirúrgico" (a incisão para a extração de um dardo). Glauco exclama que o remédio era absurdo (atopon) para um homem naquela condição, Sócrates replica dizendo que não é absurdo. Absurdas, seriam as novas doenças e a medicina que lhes era contemporânea. A medicina dos herois e guerreiros de Tróia consistia em remédios e incisões que poderiam levar até mesmo a morte; uma medicina de pessoas fortes o suficiente para aguentar a extração da doença, mesmo que fosse através de incisões ou remédios ruins, e não como a medicina de Heródico. Mas quem foi o Heródico que Platão testemunha em seus escritos e qual era seu método de tratamento?

\subsubsection{Novas terapias: Heródico e a "pedagogia da doença"}

A antiguidade testemunha sobre, pelo menos, três Heródicos: Heródico de Mégara e depois de Selimbra, Heródico de Cnido e Heródico de Leontini ${ }^{153}$; também existe a possibilidade de uma confusão entre o nome Heródico e Pródico ${ }^{154}$, entre os antigos e/ou nos manuscritos. Quase tudo que foi escrito na antiguidade tardia (principalmente Plutarco e Galeno) sobre um Heródico de Selimbra teve como fonte o texto da República, e muita confusão foi feita entre Heródico de Selimbra e Heródico de Cnido.

\footnotetext{
${ }^{151}$ Kykeon era uma bebida que consistia numa mescla de vários ingredientes (cevada, queijo ralado, vinho, etc) em diversas proporções.

${ }^{152}$ Vinho Prâmnio, segundo Ateneu de Naucratis, 1, 10b, era um vinho forte, saudável e saciava a sede, mas há dúvidas se este nome se refere à região ou ao vinho em si . O vinho tinha propriedades anti-inflamatórias e antisépticas. Contudo a interpretação de Platão era diferente apelando, possivelmente, pelas conhecidas propriedades inflamatórias do queijo, cf. Das doenças, Littre, VII, p.548-9.

${ }_{153}$ Irmão do sofista Górgias de Leontina e citado en passant por Platão no Górgias 448b.

${ }^{154}$ Cf. Arist. Rh. 1400 b 16-22; Plin. H.N. 29. 4.
} 
O Anonymus Londinensis cita dois Heródicos, o de Cnido (4. 40 - 5. 34) e um desconhecido (9. 20-36). O primeiro aparece depois de Êurifon de Cnido defendendo a tese seguinte para explicar a causa das doenças: quando o excesso de alimentos se encontra em desequilíbrio com os exercícios, os nutrimentos não são assimilados ficando indigestos e inalterados, os quais são chamados resíduos (perissomata) que por sua vez produzem um humor ácido e outro amargo. O segundo é identificado por Jones (1947, p.48-9) como sendo o Heródico de Selimbra que Platão descreve. O leitor que seguir o texto de Jones irá identificar o segundo Heródico com Heródico de Selimbra, e com ideias similares aos do autor do Regime, cuja autoria é atribuída a Heródico ou a um discípulo. Joly (2003, p.35), pelo contrário, pensa que este tratado não poderia ter sido escrito por Heródico de Selimbra, pois o Regime (1.24) levanta uma violenta critica contra a profissão de diatribe. Acrescenta-se que o tratado possui características de uma medicina eclética onde se notam ideias de Heráclito, Empédocles, Pitagóricos, de Anaxágoras e sua escola, de Hípon, da sofística, de outros tratados do Corpus hippocraticum e possivelmente de Demócrito ${ }^{155}$. Por isso, não se pode identificar uma corrente ou um só autor em que ele possa ter se inspirado. Recentemente, Daniela Manetti (2005, p.297) demonstrou que este texto de Diels foi uma construção, pois o original do papiro é demasiado lacunar (ver Apêndice 2), deixando a identidade do segundo Heródico, no Anonymus, desconhecida.

O Heródico da República III apresenta semelhanças com o Heródico citado em outros lugares do Corpus de diálogos, no livro das Epidemias e na Retórica de Aristóteles. Ele é representado no Protágoras (316e) como sendo um sofista de importância comparável à de qualquer outro que dissimulava a sofística com roupagem de atletismo, temendo o ódio que ela suscitava. No Fedro (227e), Sócrates diz que está interessado em ouvir Fedro e que não deixaria de acompanhá-lo mesmo fosse até Mégara, para, como diz Heródico, ir até a muralha e voltar. Essa imagem do professor de ginástica está ironizada na República (406a-b). Sócrates diz que Heródico viveu adoentado, combinando ginástica com medicina, e isto serviu para atormentá-lo e a muitos outros. Ele passou o resto de sua vida cuidando da doença,

\footnotetext{
${ }^{155}$ Joly (2003, p.35) explica que "on a abjecté à cela, avec raison, me semble-t-il, que le pédotribe Hérodicos ne pouvait guère écrite la violente diatribe du chapitre 24 contre as propre profession. L'auteur du Régime semble aussi plus sistématique; Il raffine sans doute l'anthropologie, qu'il prolonge em cosmologie; Il développe l'étude des aliments, boissons et exercices: nous n'avons aucune raison de croire qu'Herodicos ait publié em ces matières une somme aussi complete que le Regime n'aurait eu qu'à piller".
} 
renunciando ocupações, "angustiado quando transgredia toda dieta habitual", e arrastando uma vida languescente atingiu a velhice, conseguindo um belo prêmio ${ }^{156}$ devido à sua techne.

Este testemunho parece estar de acordo com a descrição de Heródico no livro das Epidemias (6. 3. 18) e de Aristóteles na Retórica (1. 5.3). O autor hipocrático critica um Heródico que tratava dos pacientes que se encontravam em um estado febril com passeios longos, lutas e banhos de vapor. O autor continua explicando que o estado febril é contrário a passeios, lutas, corridas e fricções; e adverte que não se deve curar a fadiga com a fadiga. Aristóteles conceitua a saúde como a excelência do corpo, ou seja, o corpo sem enfermidades. Ele atesta que muitos estão "sadios" da mesma forma que Heródico, isto é, abstendo-se de todos os prazeres humanos. Esta "saúde", continua o Estagirita, não é considerada como felicidade por ninguém. Nestes textos, Heródico aparece como um outsider, à margem da tradição médica. Porém, Platão usa a figura de Heródico como representante da "nova" medicina.

O texto da República não parece atacar a união da ginástica com a medicina, pois Platão já tinha apontado essa união no analogon do Górgias (vide acima), onde a teoria do cuidado com o corpo constitui uma arte composta de duas partes: ginástica e medicina. Nem parece condenar, nele, a medicina dietética em si, pois a palavra diaita aparece com um sentido muito geral e vago de "regime de vida" (MANETTI, 2005, p.301). Por culpa da tradição posterior, que associou Heródico de Selimbra com Heródico de Cnido e o relacionou à criação da medicina dietética, criou-se uma ideia de que Platão estaria criticando o nascimento da medicina dietética em Heródico ${ }^{157}$.

Sem dúvida que Heródico é um marco que divide a medicina de Asclépio e as novas práticas terapêuticas. Assim como o tempo de Asclépio é confrontado com os tempos de Heródico, a chamada "medicina de agora" $" 158$. No primeiro, a medicina consistia em curar ferimentos através da incisão e de remédios. A segunda forma de tratamento foi denominada

\footnotetext{
${ }^{156}$ Platão faz um trocadilho com as palavras velho ( $\left.\gamma \tilde{\eta} \rho \alpha \varsigma\right)$ e prêmio ( $\gamma \dot{c} \rho \alpha \varsigma$ ).

${ }^{157}$ Esta é a ideia que Vegetti $(1995,1996,1998)$ defende. Ele pensa que a figura de Heródico, no Protágoras e no Fedro, é um anti-Hipócrates; na República, Platão não cita Hipócrates, o incluindo assim na figura de Heródico e criticando toda uma medicina dietética que se tornara um mero ritual higiênico. O texto da República não me parece dar bases suficientes para afirmar isto, Heródico é contraposto a Asclépio, e não é relacionado com a medicina dietética, mas com a forma de tratar as doenças deixando as ocupações para criar o que chamamos hoje de hipocondríaco.

${ }^{158} \tau \tilde{\eta}$ vข̃v i $\alpha \tau \rho \iota \tilde{n}$. A palavra "agora", na expressão "a medicina de agora", não deve ser entendida como a data dramática, nem a data em que foi escrita a República, pois esta é desconhecida. Em vez disso, "agora" deve ser entendido como o tempo em que Platão vivia; como o testemunho de uma transformação social e das technai que operavam neste período.
} 
por Platão como "pedagogia da doença""159, ou seja, aquela acompanha assiduamente a doença. Mesmo que não possamos afirmar com segurança que Heródico era médico ou dietético, a sua figura foi evocada por Platão como representante desta nova medicina. Se fosse comprovada a coincidência da datação dos livros das Epidemias e da República, poderíamos dizer que Platão se está apropriando da crítica que os médicos fizeram de Heródico para lançá-la contra eles.

De qualquer forma, essa era uma época em que os homens não queriam tomar remédios amargos e temiam a extração das doenças por incisão ou cauterização, da mesma forma que eles não queriam retirar de si a injustiça através de uma punição legal. O belíssimo texto do Górgias (478a -480d) indica o medo que os atenienses possuíam da punição, "as voltas que faziam para escapar da justiça nos tribunais", como diz o texto da República (405bc); e o temor dos tratamentos médicos procurando fugir através de uma "pedagogia da doença".

A "pedagogia da doença" era contraposta ao projeto de pedagogia da cidade e à pedagogia da dieta ${ }^{160}$. "Pedagogia" não tinha a conotação positiva ${ }^{161}$, mas irônica. Platão diz

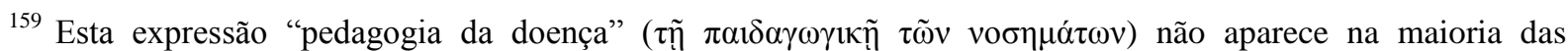
traduções em português. Albertino Pinheiro (1956) traduz como "levar as moléstias pela mão": Não será estranho se refletires em que antes de Heródico, os discípulos de Esculápio não se serviam do método de curar, tão em voga hoje em dia e que consistia em levar, por assim dizer, as moléstias pela mão. Maria Helena da Rocha Pereira (1949) traduz como "passo a passo": Não o era, se pensares que os Asclepíades não exerciam a medicina que agora se pratica, que acompanha a doença passo a passo, antes de Heródico. J. Guinsburg (2012) traduz também como "passo a passo": Não se levares em conta que a medicina atual segue passo a passo as doenças, só foi praticada pelos Asclepíades antes da época de Heródico. Pietro Nasseti (2001) também segue a tradução de Maria Helena: não o era se pensares que os Asclepíades não exerciam a medicina que agora se pratica, que acompanha a doença passo a passo antes de Heródico. O texto de Ana Lia Amaral de Almeida Prado (2014) traduz como "recursos": Não se pensas que, segundo dizem, os discípulos de Asclépio antes de Heródico não usavam os recursos de hoje para a cura das doenças. O texto das edições Gredos traduzido por Conrado Eggers Lan (1986) diz: Non tan absurdo si reflexionas que, antiguamente - según se dice, antes de Heródico -, los Asclepíades no praticaban el arte de atender enfermidades, la medicina atual. A tradução para a língua hispânica de Jose Antonio Miguez (1990) traduz de forma diferente: No te lo parecerá si piensas por un momento que la terapêutica llamada pedagógica, y que hoy se denomina yátrica, no era usada por los discípulos de Asclépio para combatir las enfermidades, por lo menos, según dicen, antes de Heródico. O texto francês de Robert Baccou (1966) traduz também por "passo a passo": Non, fis-je observer, si tu réfléchis que la médecine actuelle, que suit pas a pas les maladies, ne fut point pratiquée par les Asclepíades avant l'époque d'Hérodicos. Paul Shorey (1930) traduz por "coddling medication of disease": Not so strange, if you reflect that the former Asclepiads made no use of our modern coddling medication of disease before the time of Herodicus. Allam Bloom (1968) traduz como "education in disease": No it isn't if only you recognize the this current art of medicine which is na education in disease was no used by the Asclepíads of former times, or so they say, until Herodicus come on the scene. Veggeti (2013) traduz como "pedagogia delle malattie": No almeno se pensi che questa 'pedagogia delle malattie' in cui consiste la medicina di oggi no fu praticata dai primi Asclepiadi, a quanto dicono, prima dell'avvento di Erodico.

${ }^{160}$ Platão parece consciente da sua crítica. O Timeu, diálogo que apresenta um projeto de uma "pedagogia da

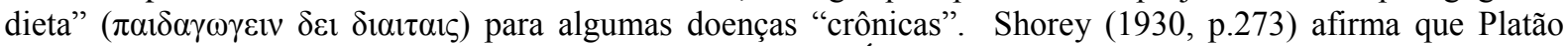
rejeita a pedagogia da doença aqui, mas a aceita no Timeu. É possível que Platão esteja criticando a medicina dietética decadente no texto da República.
} 
que Asclépio não ensinou tal medicina aos seus descendentes, não por inexperiência (ouk avnoiai) ou por ignorância (oude apeiriaitoutou), mas porque sabia que, em uma cidade com boas leis (eunomoumenois), cada um tem uma tarefa a cumprir e não pode "ter o luxo (lazer)" (oudeni schole) de viver uma vida doente e tratando-se.

\subsection{Novos doentes: os dois grupos.}

Após uma crítica violenta às novas doenças que surgiram pela incontinência da cidade, Platão ataca as novas práticas baseadas no prolongamento das doenças. Ele usa Heródico como exemplo de uma medicina "decadente". Tanto Aristóteles, quanto o autor das Epidemias criticavam suas práticas. O Heródico de Platão era o representante de uma prática médica que Platão ironiza, a que chama "pedagogia das doenças".

Agora, Platão não está atacando somente Heródico. O sujeito da frase muda para hemeis (406c) ${ }^{162}$. Platão critica as consequências desta medicina: a separação entre a dieta do artesão e a dieta do rico. Esta separação se encontra também em um livro do Corpus hippocraticum, o Regime. Devemos ter cautela ao aproximar o Regime da República, pois não sabemos a datação exata dos dois. Mas não há dúvida que as suas ideias circulavam na Atenas dos séculos V e IV. Platão não aceita a divisão entre ricos e pobres na cidade, mas admite que exista uma separação entre dois grupos de pessoas. Esta nova divisão se dá entre o grupo que realmente mereça ser curado e o grupo que não deve ser tratado.

\subsubsection{A medicina dietética e a divisão dos pobres e dos ricos.}

É quase unânime entre os estudiosos ${ }^{163}$ que Platão está fazendo uma crítica às ideias que estão presentes no tratado do Regime (3. 68-69). O autor hipocrático diz ter feito uma descoberta de uma dieta destinada às pessoas que têm necessidade de prosseguir a vida. Estas

${ }^{161}$ Penso que Platão não estava criticando o ato do médico instruir os pacientes, pois ele elogia este ato nas Leis. Aqui a pedagogia seria mais bem descrita como a condução à doença, porém conservamos o termo "pedagogia" (entre parêntesis) para enfatizar o contraste com a pedagogia que Platão propunha.

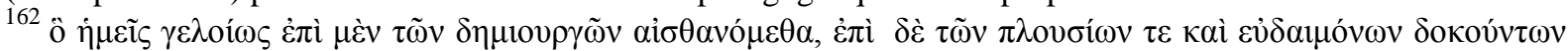

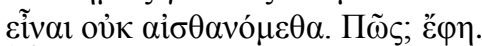

${ }^{163}$ Vegetti (1995, p.83; 1998, p. 435-9), Joly (1960, 125-36; 2003, p.34-6, 46-7), Bourgey (1953, p.129), Gual (1986, p.84-91), Jouanna (1993, p. 232-3) 
pessoas estão sempre fazendo trabalhos obrigados, viagens forçadas por suas necessidades e travessias por mar em busca de sustento; sempre expostos ao sol e submetidos ao frio. Joly (1960, p.125-167) defendeu a tese de que uma divisão entre dieta dos "pobres" e dos "ricos" seria arbitrária, pois no Regime o autor aconselha aos "pobres" a ingestão de carne e também aconselha vários exercícios (prolongados, passeios matinais, vômitos, seleção refinada de alimentos, caminhadas noturnas) que se aproximavam mais da vida de uma elite que dos artesãos. Jeanne Doucatillon (1969, p.33-42) contesta $^{164}$ a tese de Joly, explicando que a carne é um acompanhamento (opsa) e o regime descrito pelo autor parece ser demasiado complexo para o leitor moderno, mas ele segue uma regra básica do regime anual como era característico da medicina dietética do fim do século V. aEN. Esta consistia em seguir o desenvolvimento do ano, adaptando-se minuciosamente o regime à estação, se posicionando como inimigo de mudanças bruscas. Segundo o autor, quando estiver frio, o paciente deve praticar bastantes exercícios, e, quando estiver quente, fazer o contrário. Este regime era acessível a todos, tanto a ricos ociosos, como artesãos atarefados em suas obrigações.

O "escândalo" de Platão nesta divisão dos dois públicos não consistia no fato de estes médicos dietéticos pensarem que o artesão não deveria se dar ao luxo de possuir uma dieta $\operatorname{longa}^{165}$ (o que era o certo), mas que o rico deveria se dedicar a uma vida sem preocupações, cuidando da saúde como seu maior bem. Segundo Platão, eles não estariam cuidando da saúde, mas sim da doença. Na verdade, o artesão não tem tempo para uma longa dieta (makran diaitan), porque está demasiado ocupado para interromper os seus assuntos e preocupar-se com bandagens ${ }^{166}$. Ele pede ao médico um tratamento "tradicional", que segundo o Corpus hippocraticum, consiste em remédio (pharmakon) para vômitos ou purgação, práticas cirúrgicas (tome) e cauterizações (kausei) ${ }^{167}$. Se o médico prescreve uma dieta longa, ele volta à sua dieta costumeira e recobrará a saúde ou falecerá.

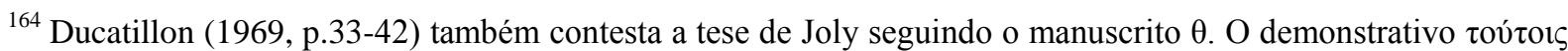
serve de antecedente ao relativo ousi. Mas o manuscrito $\theta$ fornece oto em lugar de ousi. Com isso é impedido religar o demonstrativo plural a um relativo singular. De outra parte usar a preposição pros seguido de dativo parece estranho para indicar uma pessoa ou categoria, no normal se usa o acusativo. $\mathrm{O}$ editor de $\theta$ prefere pros toutois que pros touteous. Assim expressão significara, "outro, indicando a recomendação deste heurema à uma elite rica, e contestando assim a tese de Joly que a divisão é arbitrária.

${ }^{165}$ A medicina dietética, através de seus discursos, práticas culinárias e terapêuticas se mostrava como sendo um dos maiores brinquedos dos ricos na Antiguidade (EDELSTEIN, 1960, p.306).

${ }^{166}$ Adam (1902, p.177) diz que $\pi \imath \lambda i \delta \imath \alpha ́$, as bandagens de lã, eram usadas pelos artesãos. Possivelmente Platão se refere à uma bandagem especial, que poderia atrapalhar o ofício ou mesmo bandagens teatrais que alguns autores hipocráticos condenavam (Off. 4)

${ }^{167} \mathrm{O}$ autor dos Aforismos (7. 87) resume estas práticas. Sobre a purgação através dos remédios, cf. Nat.Hom.5, 20. Sobre a incisão, cf. Nat.Hom.11; Morb. 2. 18; Mul. 1. 77; Epid. 5. 6. Sobre cauterização, cf. De arte 8; Morb. 2. 12 ; Epid. 5.7.
} 
O rico procurava um tratamento mais demorado que se tornava um empecilho para a prática da virtude. Ele prefere passar a vida alimentando as doenças do que seguir o dito de Focílides ${ }^{168}$ : "sempre que se tenha para viver, cumpre exercitar a virtude" ${ }^{169}$. Estes ricos, concorda Glauco (407b), cuidam do corpo além do que a ginástica ${ }^{170}$ exige, deixando de lado a administração da cidade, da casa e a participação militar.

A saúde foi literalmente deificada na época de Platão. Hygieia foi considerada deusa da saúde por volta do ano $400 \mathrm{aEN}^{171}$ (EDELSTEIN, 1998, p.89). Também não faltavam encômios à saúde no século $\mathrm{V}$ aEN. Platão cita uma canção recitada nos banquetes (Grg. 451d-e), possivelmente da autoria de Epicarmo ou Simônides, onde o autor enumera os bens do homem: primeiramente a saúde, depois a beleza e a riqueza. Dodds (1959, p.200-1) diz que o verso reflete a opinião da beleza segundo a aristocracia grega e a opinião do vulgo sobre a saúde, o que é confirmado por Aristóteles (Rh. 1394b).

Além disso, encontramos várias expressões no Corpus hippocraticum (Nat.hom. 23) que exaltam a saúde como o maior de todos os bens do ser humano. No Regime (Vict. 69), depois que o autor descreve o regime anual dos menos favorecidos, ele se dirige a uma outra classe de pessoas que tem recursos financeiros e que reconheceram que a saúde é superior aos bens e às riquezas. Para elas, o autor hipocrático diz ter descoberto (esti moi diaita ekseuremene) uma dieta que se aproxima o mais possível do maior grau de verdade. Ele passa a explanar uma longa dieta (Vict. 69-85) que envolve a alimentação, as bebidas, o sono, as relações sexuais, o banho e os exercícios. Segundo Levin (2014, p.41-72), a medicina dietética queria dominar áreas da vida do homem que deveriam ser coordenadas pela filosofia, por isso a filosofia de Platão lhe faz uma severa oposição.

A medicina dietética ${ }^{172}$ não visava somente à alimentação, mas um conjunto mais vasto de atividades que incluíam o sono, os banhos, os passeios e a atividade sexual. A

\footnotetext{
${ }^{168}$ Focílides de Mileto ficou conhecido por seus ditos gnômicos em versos elegíacos e hexâmetros no século VI aEN. Só conhecemos esses ditos de forma fragmentária, conservados na obra de autores diferentes, coletados e reconstituídos por Bergk (1843, p.338-342). Bergk (1843, p.340) reconstitui este fragmento (fr.10) da seguinte

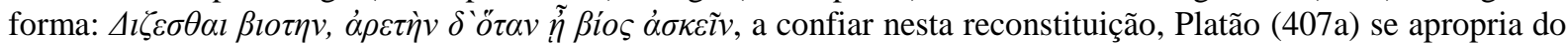
dito de Focílides, modificando-o para seus propósitos.

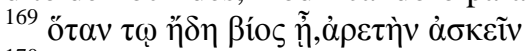

${ }^{170}$ Mais uma vez pode-se notar que Platão não está contra a ginástica. Adam (1902, p.178) afirma que a palavra

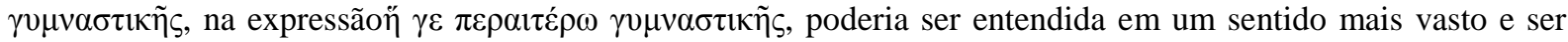
traduzido por: "este excessivo cuidado do corpo, que vai além do que o regime do corpo permite".

${ }^{171}$ Antes disto Higieia (Higia ou Higeia) não apareceu relacionada com a família de Asclépio (EDELSTEIN, 1998, p.89). Depois de sua deificação, ela aparece ora como filha, ora como esposa de Asclépio.

${ }^{172}$ A palavra dieta (diaita) aparece em Alceu uma vez, em Píndaro duas vezes, em Ésquilo uma vez, mas aparece sete vezes em Aristófanes, dez vezes em Tucídides, dezenove vezes em Heródoto, vinte vezes em Xenofonte e
} 
dietética ou o regime não devem ser vistos como uma invenção grega. Em todo caso, os escritos hipocráticos são os documentos mais antigos sobre este tema e constituem uma informação rica sobre os alimentos, juntamente com a comédia antiga e as deduções feitas pelos estudos da arqueologia nas latas de lixo da antiguidade, no arado primitivo, e nas lâminas de obsidiana (CRAIK, 1995, p.387ss). A dietética foi propícia para se construir uma medicina social que interage nas diversas interfaces de um costume ou ethos de determinado povo com o pretexto de curar as enfermidades.

No Corpus hippocraticum, a palavra diaita aparece com o sentido de "tratamento", mas a dietética não possui somente fins terapêuticos (JOLY, 1966, p.120-154) ${ }^{173}$ : ela serve para preservação e promoção da saúde, bem como para a prevenção das doenças. Edelstein (1960, p.303-16) e van der Eijk (2005, p.114) levantam a hipótese de que a medicina na época de Hipócrates estava dividida entre farmacologia, cirurgia e dietética ${ }^{174}$. Possivelmente a dietética também se dividiu em uma parte terapêutica e outra parte higiênica (preservação da saúde). Wilkins (2006, p.225-7) acredita que a medicina dietética assumiu um corpo “doutrinal" ainda no século de Hipócrates e se desenvolveu com Mnesiteu de Atenas e Diocles de Caristo.

Acrescenta-se que a medicina dietética fez o rico se tornar "nosotrófico". Platão cunha a palavra "nosotrofia ${ }^{175, ", ~ i s t o ~ e ́, ~ o ~ a t o ~ d e ~ c r i a r, ~ e d u c a r, ~ a l i m e n t a r, ~ e n g o r d a r ~(t r e p h o) ~ a s ~ d o e n c ̧ a s ~}$ (nosos). Contudo, o maior empecilho que a "nosotrofia" e o cuidado excessivo do corpo podem trazer é a dificuldade para o estudo da filosofia (407c).

A dedicação para filosofia é imprescindível para curar a cidade (e a alma) enferma. Esta fixação em cuidar do corpo impede a reflexão interior, logo o homem estaria fadado a viver sem a prática da virtude, com uma alma sempre enferma, não somente impossibilitado de curar-se, mas sempre achando fugas (tais como tensões ou dores de cabeça) para a cura.

mais de duzentas vezes no Corpus hippocraticum (JOUANNA, 2012, p.139). O sentido de diaita não é unânime dentro do Corpus. No Da medicina antiga, tanto significa "dieta alimentar", como "bebida" e "comida". No Da

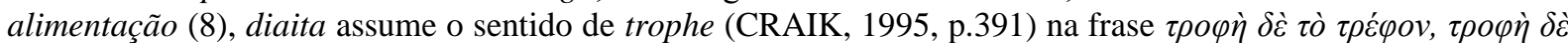

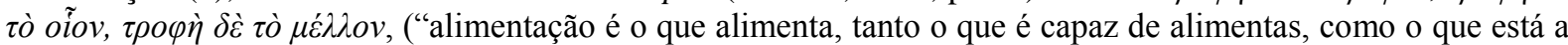
ponto de alimentar"). No segundo sentido, a palavra diaita inclui exercícios (Aër.1). A palavra diaita também foi utilizada com o sentido mais estrito de "modo de vida", "maneira de viver", como sinônimo de ethos (Aër.18). No Do regime nas doenças agudas e no Do Regime a palavra diaita aparece relacionada com elementos adicionais como o banho e o coito. $\mathrm{O}$ autor do primeiro tratado termina com uma discussão sobre o uso do banho

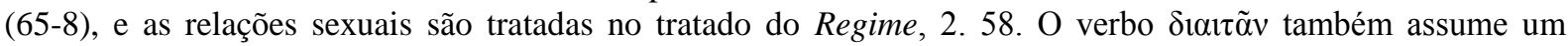
sentido de therapeuo, "tratamento" (Epid. 3. 16).

173 Ver também, van der Eijk, 2005, p.113-4.

${ }_{174}^{174}$ Aff. 4, 9, 15, 18; Vid.Ac. 64; Morb.1.14; Acut.(Sp.) 4; Int.24, 50.

175 De acordo com Liddell-Scott a primeira aparição da palavra é em Platão. Chantraine mostra uma predominância da relação entre o verbo dórico $\tau \rho \varepsilon \varphi \omega$ com alimentar. 


\subsubsection{A medicina de Asclépio e a divisão entre curáveis e incuráveis.}

Sócrates defende que Asclépio não ensinou este tipo de medicina, a saber, toda esta "pedagogia da doença”. Em vez disso, a medicina de Asclépio servia para curar doenças localizadas (407c-e), não prescrevendo uma dieta que não fosse a costumeira, expulsando as doenças através de remédios e incisões:

Sem dúvida podemos afirmar que Asclépio conhecia isto e teve em conta àqueles que, mantêm saudáveis seus corpos graças à natureza e ao regime que seguem, mas sofrem de uma doença delimitada; afugentou as doenças com remédios e incisões, mas prescrevendo a dieta costumeira de modo que não prejudicava as atividades políticas. Porém nos corpos inteiramente afetados pela doença interna, não tentou, com graduais interventos dietéticos de evacuações e infusões, prolongar a vida de um homem, nem os deixou em condições de engendrar filhos condenados a se assemelhar, provavelmente; mas não supôs que fosse necessário cuidar de um que não estivesse em condições de viver em um período determinado, porque não seria proveitoso nem a ele e nem a cidade.

Falas de Asclépio como se ele fosse um político. ${ }^{176}$

O texto diz que Asclépio não prescrevia nenhuma dieta que não fosse a costumeira, porque esta dieta do tempo de Asclépio era saudável. Nota-se que o texto começa dizendo que

\footnotetext{
${ }^{176}$ Tradução própria baseada na tradução de Mario Vegetti e Maria Helena da Rocha Pereira. Orig.: oủкoũv

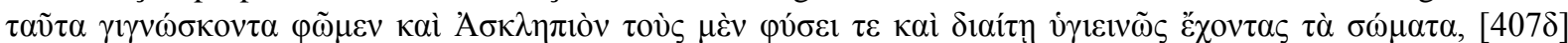

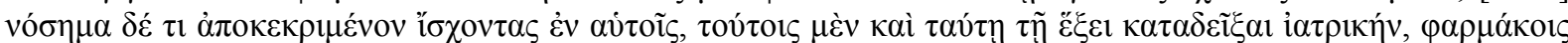

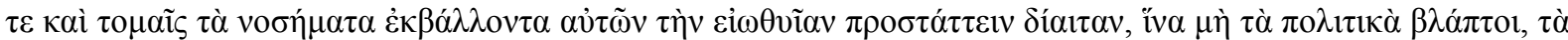

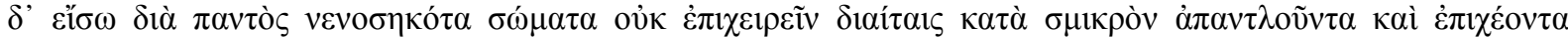

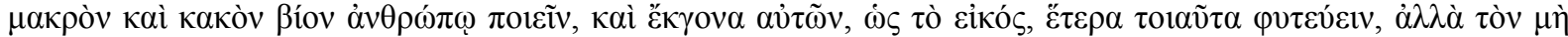

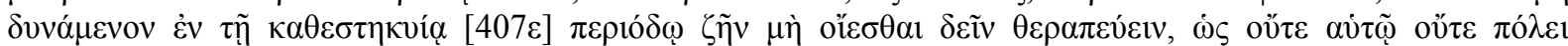
$\lambda v \sigma i \tau \varepsilon \lambda \tilde{\eta} ;$

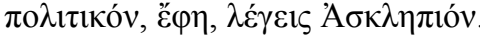


Asclépio teve em conta aqueles que mantêm saudáveis seus corpos graças à natureza e ao regime que seguem, mas que sofrem de uma doença delimitada. Então, se o homem seguisse uma dieta saudável, um regime de vida apropriado e equilibrado, seguramente não padeceriam com novas doenças, nem necessitariam de um tratamento prolongado $^{177}$.

Sócrates fala de um segundo corpo, que está tomado completamente pela doença interna (407d: pantos nenosekota); é enfermo por natureza (408b: nosode de physei) e incontinente (akolaston). A medicina foi criada para atender o primeiro tipo de corpo, porque ao segundo não se deve prolongar a existência além do que foi fixado pela natureza e não se deve proporcionar condições para que ele engendre filhos. Glauco, ouvindo isso, exclama que Asclépio é um político.

O texto acima (407d-e) pode causar desconforto aos leitores modernos, mas ele deve ser interpretado à luz da medicina da época e do contexto. $\mathrm{O}$ autor do tratado Da arte (3) define a medicina como apartar todos os sofrimentos dos doentes, acalmar os ataques das doenças e a não tentar curar os que estão tomados pela doença. Outros tratados também possuem a interdição de não tratar dos pacientes que estão perto da morte (Morb. 2. 48; Mul. 1. 71). Contudo, nem todos os médicos partilhavam das exigências teóricas do autor Da arte. Nos tratados "cirúrgicos", havia recomendações para que se tratasse do paciente acidentado, mesmo se este se encontrasse inconsciente (Fract. 36; Art. 58) e também havia casos que o médico deveria decidir pelo tratamento ou não.

No mito do Fédon (107a - 115a), Sócrates diz que a alma incurável é lançada ao Tártaro, de onde não sairá nunca mais (Phaed. 113d-114c), mas a alma que, mesmo cometendo injustiça, seja purificada pela filosofia, subirá às moradas belas. Na República, o "deixar morrer" da medicina e o "condenar à morte" da justiça estão reservados às pessoas que possuem uma alma perversa por natureza e incorrigível. Estas seriam danosas à cidade. O papel político do médico será julgar e decidir sobre as naturezas e deixar morrer as que estão tomadas pela doença.

\footnotetext{
${ }^{177}$ Foucault (1998, p.92) afirma que "a dietética aparece, segundo esta gênese, como uma espécie de medicina para os tempos de lassidão; ela era destinada às existências mal conduzidas e que buscam prolongar-se. Vê-se, contudo, que, embora para Platão a dietética não seja uma arte originária, não é porque o regime, a diaite, não tenha importância; a razão pela qual, na época de Asclépio ou de seus primeiros sucessores, não existia uma preocupação com a dietética, é que "o regime" realmente seguido pelos homens, a maneira pela qual eles se alimentavam e se exercitavam era conforme à natureza."
} 
Sócrates continua dizendo que Asclépio era político e seus filhos também, pois, além de praticarem medicina, eles lutaram bravamente ${ }^{178}$ na guerra de Tróia (408ab). Eles curaram a ferida de Menelau, sugando o sangue e polvilhando o remédio ${ }^{179}$. Depois do tratamento eles nada lhe prescreveram, sabendo que os remédios eram suficientes para curarem, pois este se encontrava são e observando um bom regime. Mas não havia vantagem em prolongar a vida do indivíduo doente por natureza. Antes de chegar à conclusão de que Platão estava pregando uma "engenharia social", devemos ver a quem era endereçada esta interdição de curar:

\begin{tabular}{|l|l|}
\hline \multicolumn{1}{|c|}{ Primeiro grupo } & \multicolumn{1}{c|}{ Segundo grupo } \\
\hline $\begin{array}{l}\text { 1. Pode sofrer de uma doença localizada, } \\
\text { sazonal ou ferimentos. }\end{array}$ & 1. Corpo tomado pela doença \\
\hline $\begin{array}{l}\text { 2. Sadio (hygieinos) e segue um regime } \\
\text { sadio segundo a natureza. }\end{array}$ & $\begin{array}{l}\text { 2. Enfermo por natureza (nosode de physei) e } \\
\text { incontinente }\end{array}$ \\
\hline $\begin{array}{l}\text { 3. Tratava-se com remédio, incisões e } \\
\text { cauterizações. }\end{array}$ & $\begin{array}{l}\text { 3. "Alimentava" as doenças, cuidado do corpo } \\
\text { que vai bem além dos limites da ginástica. }\end{array}$ \\
\hline $\begin{array}{l}\text { 4. Tratava-se sem prejudicar os negócios da } \\
\text { cidade. }\end{array}$ & $\begin{array}{l}\text { 4. Negligencia a virtude, os assuntos } \\
\text { domésticos, as obrigações civis e militares. }\end{array}$ \\
\hline
\end{tabular}

A techne terapêutica não foi feita para o segundo grupo, mesmo que fossem mais ricos que Midas. A interpretação do texto pode ser prejudicada, se a leitura for condicionada pela sobrevalorização de um só aspeto de tal contradição, de tal forma que Platão condenaria todo doente crônico à morte, o que o texto não diz. A medicina estava tratando de um homem que não somente estava tomado de doenças, mas era doente por natureza.

Por fim, parece estar implícito que:

\footnotetext{
${ }^{178}$ No Discurso da Embaixada (L. IX, p.426), texto apócrifo possivelmente escrito no período helenístico, encontra-se um testemunho que os filhos de Asclépio lutaram como guerreiros e como médicos.

${ }^{179}$ Platão opera outra crase do texto homérico. Na Ilíada IV, 218-9: depois de examinar o ferimento aberto pela flecha e sugar-lhe o sangue, põe na chaga um bálsamo.
} 
a) medicina não foi criada para os que são incontinentes por natureza (408b), pelo que estes buscam a doença com seu estilo de vida;

b) eles fazem parecer que estão sempre doentes e a doença se torna para eles uma desculpa para escapar das obrigações com a cidade;

c) eles querem um tratamento brando, pois parecem doentes, mas na verdade a enfermidade tem origem moral.

Então, condená-los a morte seria uma ironia. Porém, não podemos ignorar que Platão se apropria de uma interdição, presente em algumas obras do Corpus hippocraticum, de curar aqueles que estão dominados pela doença. Parece que Platão está se apropriando da medicina para polemizar contra ela.

\section{ALGUMAS CONCLUSÕES PRELIMINARES.}

A República começa com uma discussão sobre o que é a justiça. Como parte do elenchos socrático, a craft-analogy aparece como um poderoso elemento para refutar as opiniões de Trasímaco. Entendemos que não há uma representação no texto platônico do Trasímaco histórico, mas sim que a personagem representa opiniões que podem estar relacionadas com Antifonte, Tucídides e com os médicos hipocráticos.

Nos livros seguintes da República, Sócrates não é abandonado. Contudo, ele passa a responder a outras pessoas (Glauco e Adimanto) com indagações sobre o mesmo tema (justiça), mas que o reformularam de tal maneira que Sócrates teve que alterar seu método de investigação. Ele faz um analogon entre a cidade e o indivíduo. Este analogon conserva a 
comparação com as technai e não deixa de lado seu caráter polêmico, antes vai além da craftanalogy: ele é apto a discernir conceitos.

Sócrates passa a descrever o regime dos guardiões. Segundo ele sua dieta deveria ser saudável. Neste instante, faz uma digressão onde compara o regime dos guerreiros e o regime da cidade. Nesta digressão, o aumento de tribunais e de clínicas é criticado. Juntamente com eles, Platão tece uma crítica contra todo "sistema de saúde".

Nesta crítica, constatamos que Platão parece se apropriar dos conceitos da medicina para criticá-la. Esta crítica tem como alvo:

a) as novas doenças, flatulências e catarros, não estão relacionados com uma dieta cárnea, antes com um regime de vida como atesta o tratado Regime. Para Platão, estas doenças vão além dos escritos hipocráticos: elas são fruto de um regime de vida descomedido da polis luxuosa;

b) mesmo que não se possa relacionar Heródico de Selimbra com o Heródico do Anonymus, temos a garantia de que ele era uma personagem que foi atacada na Antiguidade por Platão, pelos médicos e por Aristóteles. Platão, não está criando um anti-Hipócrates, como pensa Vegetti, antes parece que está usando uma caricatura, que os próprios médicos combatiam, para sintetizar nele toda a medicina de sua época;

c) na Guerra de Tróia, os guerreiros se tratavam com remédios e cirurgias, muitas vezes de risco. Eles eram sãos e seguiam um regime são. Platão evoca a medicina de Asclépio, e não de Homero como pensa Strauss, para confrontar uma medicina languescente que ensina o cidadão a fugir de tratamentos dolorosos. Platão dá o nome de "pedagogia das doenças" a estes novos tratamentos que acabaram por criar um hipocondríaco;

d) este hipocondríaco (ou nosotrófico) tem as seguintes características: o cuidado excessivo com o corpo; a aparência de doente; ser enfermo por natureza; negligencia a virtude e as obrigações civis. Segundo Platão, ele não deve ser tratado pela medicina. Não está em causa uma "engenharia social" ou eugenia, como declara Popper. Ele defende, sim, que a medicina deve prestar um auxílio à cidade e não fazê-la adoecer mais ainda; 
e) por fim, o "progresso" de que os atenienses tanto se orgulhavam trouxe também uma série de doenças. Este "progresso" a qualquer custo está sendo criticado por Platão. Platão não é um defensor do "historicismo", pois ele rapidamente liquida a "cidade saudável" do Livro II, pela sua condição pré-política e pré-filosófica (VEGETTI, 2010, p.180). Além disso, a linguagem dos livros V e VI da República põe claramente a construção da kallipolis num futuro não ciclicamente regressivo; e em nenhuma parte da crítica à medicina Platão fala de um retorno à medicina de Asclépio. Pelo contrário, ele propõe uma reforma de todo "sistema de saúde" para que haja bons médicos na cidade.

Esta reforma está ligada aos conceitos de saúde, medicina e médicos. Desde os chamados "diálogos socráticos", há uma busca dos agathoi iatroi. Quem são os bons médicos da cidade? Há um polemos pela autoridade nas questões de saúde e doença: os médicos polemizando com médico, curandeiro com curandeiro, e médico com médico. Segundo nosso entendimento, Platão formula sua resposta no Livro III, antes é necessário revisitar os seus conceitos de saúde e medicina. 


\section{CAPÍTULO TERCEIRO}

\section{O CONCEITO DE SAÚDE, MEDICINA E MÉDICO NA REPÚBLICA.}

A definição de medicina, saúde e médico que Platão explicita na República pode ser contraposta com as definições que encontramos nos escritos hipocráticos datados mais ou menos da mesma época ${ }^{180}$. Tendo por base estes escritos que chegaram até nós sob a forma de Corpus hippocraticum, as descrições platônicas representam uma polêmica contra a medicina de seu tempo. Porém, devemos ter cuidado para não cair no mesmo erro dos positivistas, crendo que Platão polemizava contra Hipócrates ou contra uma determinada corrente (itálica ou de Cnido).

Platão demonstrou que a medicina de seu tempo estava em declínio. Ele critica o excessivo cuidado da saúde, que tinha se transformado em cuidado da doença. A saúde servia era exaltada na cidade, e agora se tornara também uma desculpa para não se ocupar com a política.

O objetivo do capítulo é mostrar que o conceito de médico que Platão delineia claramente não se alinha com as práticas dos médicos hipocráticos. Contudo, entendemos que não se pode chegar a esta conclusão sem primeiro ter esclarecido outros conceitos. Por isso, seguimos uma ordem inversa da República, analisando primeiramente a saúde (444d), depois a medicina (438d-e), para chegar ao médico (408c-e).

\section{O CONCEITO DE SAÚDE}

\footnotetext{
${ }^{180}$ Existe muita dúvida na datação. É um trabalho espinhoso e cheio de especulação. Ao falar de uma datação comum entre a República e os tratados hipocráticos, temos em mente algo mais geral, ou seja, o período que compreende a segunda metade do século V e a primeira metade do século IV. (Ver Apêndice 1)
} 
A saúde é definida no final do Livro IV quando também serão definidos os atos de justiça. Muita dificuldade se encontra no fato de o leitor relacionar, quase que instantaneamente, o conceito de justiça ao de saúde. O texto dá voltas, sendo necessário o entendimento do desenvolvimento do conceito de justiça ${ }^{181}$ e da alma tripartida no texto. Então, veremos que a saúde faz parte de outro analogon, que não é mais aquele que liga a alma tripartida à cidade.

\subsection{O conceito de justiça e a alma tripartida.}

No início do Livro IV, Adimanto protesta porque foi vetado aos guardiões (que detêm o governo da cidade) possuir alguma propriedade. Ele pergunta se esse grupo de pessoas não será infeliz. Sócrates responde que o objetivo não é tornar uma só classe muito feliz, mas garantir a felicidade da cidade inteira (419a-421c). Nesta cidade bela (kallipolis), não se deve permitir nem a pobreza nem a riqueza extrema. Pois a primeira engendra o servilismo, a ineficiência e o gosto pela novidade; a segunda engendra o luxo, a preguiça e o gosto pela novidade. É fundamental que haja uma educação pormenorizada (421d - 427c).

Estes governantes detêm um "saber governar" (428d), que consiste em uma capacidade prático-política de tomar decisões justas com vistas à vantagem da cidade inteira. A qualidade típica deles é a sabedoria (sophia, 429a). A segunda classe de pessoas, a dos guardiões, deve ser dotada de coragem (andreia). Uma coragem não é só uma virtude a ser exercida nos campos de batalha, mas é uma fidelidade aos princípios morais estabelecidos pela lei e uma educação apropriada sobre o que deveriam temer (429b-430c). A terceira qualidade (430d-432a), a temperança ou moderação (sophosyne), deve estar presente em todos os grupos sociais de forma distributiva. A temperança presente na classe dos governantes e guardiões faz com que estes não se transformem em opressores dos súditos. Já no terceiro grupo, a temperança põe limites nos prazeres, no acúmulo de riquezas, no desejo de poder.

\footnotetext{
${ }^{181}$ Existe um grande debate em torno da justiça em Platão. Não iremos enfrentar este problema, pois a definição textual é suficiente para demonstrar o analogon entre justiça e saúde. Para o debate sobre a justiça, ver Irwin (1977, p.204-216); Keyt (2011, p.318-32); Kraut (2013, p.367-97); Santas (2010, p. 55-103); Vlastos (1968, p.665-674). Deve-se ter em mente que o conceito de justiça é mais amplo do que o que foi exposto no Livro IV. Segundo Kraut, ele se desenvolve nos demais livros da República.
} 
Por fim, a justiça (dikaiosyne) garante que as outras três virtudes (sophia, andreia, sophosyne) sejam distribuídas entre os grupos sociais hierarquicamente articulados. A justiça consiste (434a):

a) em reter apenas os bens que nos são próprios. Como já notava Vlastos (1968, p.667), esta primeira metade do conceito de justiça parece polemizar com o estado de pleonexia descrito acima por Tucídides;

b) em exercer a nossa própria função, isto é, respeitar os próprios limites e o próprio papel (oikeiopragia, 434c). Na gênese da cidade, Sócrates explica a Glauco que a multiplicidade das necessidades reúne em um mesmo local um grande número de associados e auxiliares $(369 \mathrm{e}-$ 370a), e cada um deve cumprir a sua própria função (hauto prattein).

Para que a justiça seja plena, Platão não permitia a troca de funções e nem a prática de várias atividades (434b-c). É bem provável que ele esteja criticando a pressuposta liberdade democrática, que os atenienses tanto se orgulhavam, a qual permitia aos cidadãos uma versatilidade na prática e exercício de várias formas de atividades. ${ }^{182} \mathrm{Na}$ kallipolis, cada um deveria fazer sua função.

A tripartição funcional do corpo social foi introduzida para superar a cisão econômica entre ricos e pobres, que condenaria a cidade a um conflito perpétuo. A função da justiça é garantir a felicidade coletiva na oikeiopragia política dos três grupos. Agora resta transferir este modelo para a dimensão individual, segundo o método proposto no início, para ver se há algum isomorfismo entre as duas justiças (coletiva e individual).

No indivíduo existe um conflito. Platão constata que a alma se divide em três partes ${ }^{183}$ : racional (logistikon), desiderativa (epithymias) e irascível (thymoeides). A divisão é análoga aos grupos da cidade, pois cabe à parte racional, comandar; à irascível, vigiar; e a desiderativa, desejar (434c-441c). Esta última necessita de freio e direção.

Poderíamos representar assim o analogon:

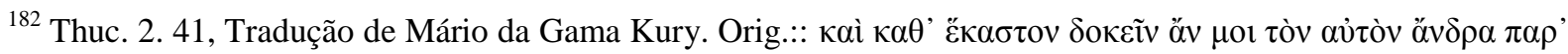

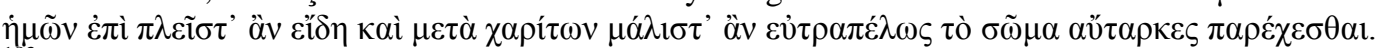
${ }^{183}$ A tripartição da alma é discutida em Robinson (2007, p.78-85), Santos (2009, p.71-80), Miller (2011, p.261275).
} 


\begin{tabular}{|c|c|c|c|}
\hline CIDADE & $\begin{array}{c}\text { Governantes } \\
(\text { sophia })\end{array}$ & $\begin{array}{c}\text { Guardiães } \\
(\text { andreia })\end{array}$ & $\begin{array}{c}\text { Artesãos } \\
\text { (sophrosyne) }\end{array}$ \\
\hline ALMA & $\begin{array}{c}\text { Racional } \\
\text { (logistikon) }\end{array}$ & $\begin{array}{c}\text { Irascível } \\
\text { (thymoeides })\end{array}$ & $\begin{array}{c}\text { Desiderativa } \\
\text { (epithymias) }\end{array}$ \\
\hline
\end{tabular}

Se há uma isomorfia entre os três elementos, então o conceito de justiça que foi aplicada à cidade também pode ser aplicada ao indivíduo.

Contudo, Vegetti (2011, p.61-2) assinala que muita dificuldade hermenêutica vem da aceitação que a forma política, em termos de força e poder, é completamente isomórfica ao conflito intrapsíquico. Platão mesmo reconhece as dificuldades, dizendo que com "os métodos que estamos a servir-nos agora na discussão, jamais atingiremos rigorosamente o nosso fim" 184 (435c-d). Ele continua dizendo que o método bastava para as presentes circunstâncias e que havia um caminho mais longo e demorado.

Este conceito de justiça, no Livro IV, possui mais um nexo causal do que isomórfico, entre a cidade e o indivíduo. Na alma, como também na cidade, a justiça consiste em uma harmonização hierárquica dos seus componentes, que aceitam o comando da parte racional e da sua aliada irascível, com a subordinação da esfera desiderativa.

\subsection{O conceito de ações justas e a saúde.}

Estabelecido o conceito de justiça, Sócrates agora se pergunta sobre o conceito de atos de justiça. Aqui reside uma grande confusão quando se lê a passagem. Como foi demonstrado acima, a justiça na alma é semelhante à justiça na cidade. Até agora a saúde não é evocada. A

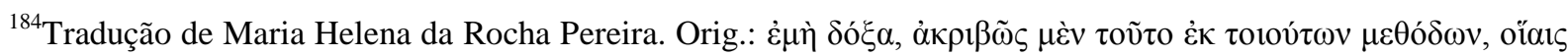

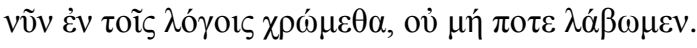


partir da passagem 444c, Sócrates constrói outro analogon, agora entre ações justas e saúde do $\operatorname{corpo}^{185}$ :

- Ora, produzir a saúde consiste em dispor, de acordo com a natureza, os elementos do corpo para dominarem ou serem dominados uns pelos outros; a doença, em, contra a natureza, governar ou ser governado um por outro.

- Consiste, sim.

- Portanto, inversamente - produzir a justiça consiste em dispor, de acordo com a natureza, os elementos da alma, para dominarem ou serem dominados uns pelos outros; a injustiça, em contra a natureza, governar ou ser governado um pelo outro. $(R .444 \mathrm{~d})^{186}$

O analogon pode ser representado da seguinte forma:

\begin{tabular}{|c|c|c|}
\hline Alma & Ações justas & $\begin{array}{c}\text { Elementos dominando } \\
\text { segundo a natureza }\end{array}$ \\
\hline Corpo & Saúde & $\begin{array}{c}\text { Elementos dominando } \\
\text { segundo a natureza }\end{array}$ \\
\hline Alma & Ações injustas & $\begin{array}{c}\text { Elementos governando } \\
\text { contra a natureza }\end{array}$ \\
\hline Corpo & Doença & $\begin{array}{c}\text { Elementos governando } \\
\text { contra a natureza }\end{array}$ \\
\hline
\end{tabular}

${ }^{185}$ Santas (2010, p.102) vê uma lacuna entre o argumento da justiça psíquica e o argumento da ação justa. Ele passa da justiça na cidade para justiça no indivíduo

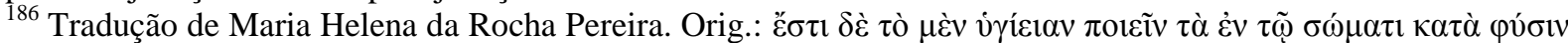

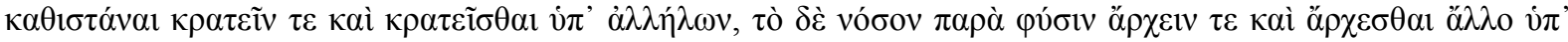

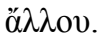

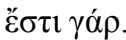

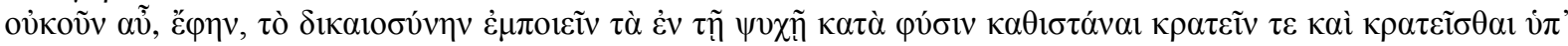

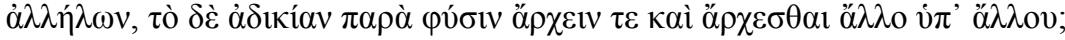


O conceito de saúde que Sócrates delineia é a dominação (krateisthai ${ }^{187}$ ) de um elemento sobre outro de acordo com a natureza, assim como o elemento racional domina os outros elementos na alma. Ele encerra o Livro IV dizendo que as constituições políticas são tantas quantas as espécies de alma. Mas a melhor delas é a monarquia ou a aristocracia.

Sócrates não se aproxima um conceito "democrático" de saúde. Não é uma isonomia dos elementos que está em jogo, mas o governo de um sobre os outros. De forma alguma a palavra harmonia aparece neste trecho do analogon acima. Não que o conceito de harmonia fosse estranho à ideia de saúde. Mas, comumente se faz uma ligação entre Platão e a medicina grega através da noção de harmonia. Reale (2002, p.188) afirma com segurança que o conceito de saúde em Platão "é a justa proporção, a harmonia natural, o acordo intrínseco do organismo consigo mesmo e com o que lhe é exterior.” Gadamer (2011, p.105), nesta mesma ideia, vai mais além dizendo que a saúde como harmonia era vista também pelos gregos e por Platão. $\mathrm{O}$ conceito de harmonia pode ser comum à medicina grega e Platão, mas eles se divergiam sobre como se processa esta harmonia.

Alcmeon é sem dúvida parte de uma tradição de filosofia da saúde ${ }^{188}$. Ele é reconhecido como uma figura de grande importância no desenvolvimento das ciências biológicas na Grécia antiga. Alguns ${ }^{189}$, inspirados no "milagre grego"190, enalteceram a figura de Alcmeon como o pai da anatomia, pais da fisiologia, da embriologia, da psicologia, e da própria medicina. Evitando cair em exagero, pode-se hoje (VEGETTI, 1965, p.94) atribuir a Alcmeon a distinção entre a inteligência e a sensação. Poder-se-á também atribuir a ele a teoria que coloca o cérebro como interprete da sensação e órgão da inteligência, bem como o primeiro experimento de dissecção ${ }^{191}$.

\footnotetext{
${ }^{187}$ Platão está usando o verbo krateo para a saúde e archo para a doença. De acordo com Chantraine (1968, p. 119-121; 578-579), é difícil precisar a etimologia da palavra archo, pode ser que ela esteja ligada com a ideia de começar, tomar iniciativa. Depois de Homero, o verbo toma o sentido de comandar. Segundo LSJ, a maioria dos vocábulos administrativos recebe a raiz arch. Já o verbo krateo tem o sentido de força física que permite triunfar, vitória, poder, soberania, controle.

${ }^{188}$ Existe uma espinhosa questão sobre a relação entre Alcmeon e os pitagóricos. Não é nosso objetivo entrar neste debate, para maiores detalhes ver Cornelli (2009, p.41). Para as teorias cosmológicas de Alcmeon ver Burnet (1994, p.159-161), Casertano (2011, p.58-9, 76-7), Schofield (1994, p.365). Para uma análise detalhada da medicina em Alcmeon ver Cornelli (2009, p.40-2), Jouanna (1992, p.459-61), Vegetti (1965, p.91-4), Longrigg (1988, p.47-81).

${ }^{189}$ Burnet (1994, p.159-61) afirma que Alcmeon foi o pai da psicologia empírica, e que Hipócrates e Platão dependem dele para descrever o cérebro como o sensório comum.

${ }^{190}$ Lloyd (1991, p.167, n2) elenca uma vasta bibliografia sobre o assunto.

${ }^{191}$ Segundo Lloyd (1991, p.178), Alcmeon não estava interessado em um método de dissecção em si, mas em problemas teóricos tal como o da sensação.
} 
Para Alcmeon (DK 24 B4) a saúde (hygieias) é a isonomia (isonomian) das forças (ton dynameon): úmido-seco, frio-quente, amargo-doce, etc. Existindo a monarquia ou a senhoria (monarchian) de um deles, produz-se a doença (nosou). A saúde (hygieian) é a mistura (krasin) simétrica (symmetron) das qualidades. A isonomia torna-se o coração da ética antiga, e "especialmente, em sentido político e jurídico: a ideia acaba permeando toda a cultura" (CORNELLI, 2009, p.40-1). A saúde para Alcmeon era "o estabelecimento de um governo livre e com leis igualitárias" (BURNET, p.1994, p.161). Segundo Vegetti (1965, p.94) a ideia de isonomia e krasis orientaram também o pensamento hipocrático, principalmente dos tratados Da medicina antiga e Dos ares, águas e lugares. Também se notam claros traços da etiologia alcmeonica nos tratados Da dieta nas doenças agudas e Epidemias.

As duas principais definições de saúde se encontram em dois tratados que, coincidentemente, rejeitam a influência da filosofia e afirmam a independência da medicina (JOUANNA, 1992, p.456-9). A primeira obra é o tratado Da medicina antiga. O autor hipocrático (VM 14) define a saúde pelo oposto, ou seja, a doença. Ele afirma que quando os elementos presentes no homem (tais como salgado, amargo, doce, etc) são mesclados (memigmena) e bem misturados (kekremena ${ }^{192}$ ) uns com os outros, eles não trazem sofrimento ${ }^{193}$, mas se um deles se separa (apokrithe) e subsiste por si mesmo (kai auto eph'eoutou), então nasce o estado doentio. Schiefsky (2005, p.248-254) explica que no texto a ideia de mistura dos componentes é feita de forma que o caráter individual de cada um não se manifeste até que sejam separados uns dos outros e se tornem concentrados.

Outra obra é o tratado Da natureza do homem. O autor (Nat.Hom. 4) define a saúde como o estado de perfeita mistura (kresios), e de proporção dos poderes ${ }^{194}$ (dynamios) e quantidades (pletheos), dos quatro elementos: sangue (aima), flegma (phlegma), bile amarela e bile negra (cholenksanthen te kai melainan). A doença, por sua vez, surge quando um dos elementos se separa em maior ou menor quantidade no corpo e não se mescla com todos os demais. Apesar das diferenças entre os tratados Da medicina antiga e Da natureza do homem, as duas definições apresentam pontos comuns:

\footnotetext{
${ }^{192}$ Jouanna (1990) e Festugière (1979) traduzem kekremena por "temprerées". Vegetti (1965) traduz por "contemperate. Schiefsky (2005) traduz por "blended". Garcia Gual (1993) traduz por combinados. O texto de Jones traz "compounded". A ideia é similar ao cozimento dos alimentos: é uma boa mistura (Liddell-Scott), quase que podemos dizer "homogênea".

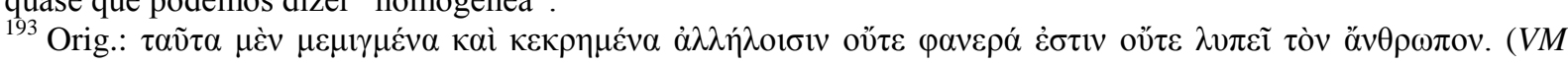
14.4, seguindo o texto de Jouanna)

${ }^{194}$ Schiefsky (2005, p.247) segue Jouanna traduzindo dunamis por poderes. O autor hipocrático considera dunamis como uma capacidade de causar um tipo específico de efeito, que também possui uma certa força ou intensidade.
} 
a) a saúde e a doença são estados radicalmente opostos;

b) a saúde é definida pela mistura de todos os elementos do corpo;

c) a doença é definida pela separação e isolamento de um elemento em relação aos outros.

Por fim, existe uma definição de saúde em um tratado eclético de inspiração filosófica, o Regime. O autor hipocrático (Vict. 69) define a saúde como a igualdade (isazein) dos fatores e a doença como a predominância (krateesthai ${ }^{195}$ ) de um fator sobre o outro. Apesar de uma semelhança com o vocabulário da República, o autor fala em um contexto diferente (JOLY, 2003, p.288-9). Aqui os fatores que ele se refere são alimentos e exercícios. Na República, Platão é mais amplo, pois ele não fala de fatores, elementos ou humores.

Mesmo que o conceito de saúde platônico não esteja almejando uma obra hipocrática especifica, parece que ele está contra uma tradição médica que teve início com Alcmeon. A crítica à medicina do Livro III somada a este conceito de saúde resulta que Platão segue em rota de colisão com o conceito hipocrático de saúde-doença ${ }^{196}$. Este conceito de saúde é fundamental para entendermos agora o conceito que ele definirá a medicina, a saber, a ciência da saúde e da doença.

\section{O CONCEITO DE MEDICINA.}

Platão precisa responder a uma questão: como a alma pode estar em conflito consigo mesma? Para isso, ele estabelece dois princípios, aos quais chamamos de Princípio da Oposição e Princípio da Qualificação. Na tentativa de responder esta questão, ele volta ao conceito de medicina. Segundo ele, a medicina é a ciência da saúde e da doença.

\footnotetext{
${ }^{195}$ Cf. $\kappa \rho \alpha \tau \varepsilon i \tilde{\sigma} \theta \alpha \imath$ R. 444d.

${ }^{196}$ Esta opinião é defendida também por Ayache (1992, p.120); Levin (2014, p.16)
} 
Esse conceito não aparece na medicina grega e não está presene como tal em nenhum dos escritos hipocráticos. Isso pode ser um indício que Platão estaria utilizando a ironia, ou estaria apresentando uma teoria sobre a medicina que não era a convencional, ou ainda estaria simplesmente utilizando a palavra saúde e doença como par de opostos. De qualquer forma, o texto é obscuro e as evidências são frágeis. Mesmo que sigamos o fio condutor de que Platão estaria polemizando contra a medicina de sua época, parece-nos (pelas razões descritas abaixo) mais sensato deixar, mais uma vez, a questão em aberto.

\subsection{O Princípio da Oposição e o Princípio da Qualificação.}

Sócrates, depois de concluir que o homem justo não difere da cidade justa (435b), passa a investigar a alma. Sua investigação gira em torno do seguinte problema: será que os três elementos da alma funcionam separadamente ou a alma como um todo realiza todas estas funções indistintamente? (436a-b). Sócrates declara que o mesmo sujeito, na mesma de suas partes, e relativamente ao mesmo objeto, não poderá produzir ou experimentar ao mesmo tempo efeitos contrários (436b). Este princípio é denominado por Reeve (1988, p.118-119) como Princípio de Oposição.

Um contra-exemplo é formulado: se alguém pretendesse que um homem encontra-se imóvel e em movimento, argumentando que ele se mantém imóvel, mas ao mesmo tempo mexendo os braços e a cabeça (436c-d). O pião é outro contra-exemplo: ele está retido no mesmo lugar por sua ponta e gira (436d-e). Sócrates refuta tais objeções dizendo que não é na mesma parte que se encontra o movimento e o repouso. A aparente violação do Princípio de Oposição só poderá acontecer se houver uma sinédoque.

Sócrates continua desenvolvendo sua argumentação demonstrando que existem contrários entre si: aprovar e desaprovar, desejar e recusar, atrair e repelir (438b-c). Ele coloca a fome e a sede nos primeiros dos contrários. A sede, enquanto sede é desejo de bebida, ou seja, de um objeto. Cada desejo é desejo de um objeto consignado à sua natureza (438a). Então, todas as coisas têm relação com um objeto: algumas são qualitativamente determinadas e relativas a um objeto determinado; e outras, por elas próprias, são relativas apenas consigo 
mesmo. A isso Reeve (1998, p.119) denomina de Princípio da Qualificação. Agora Sócrates irá adotar este princípio ao conhecimento.

\subsection{Medicina: ciência da saúde e da doença.}

Sócrates aplica o Princípio da Qualificação às technai. Ele diz que a ciência tomada em si mesmo é a ciência do cognoscível em si mesmo. Também ela pode ser a ciência de uma coisa determinada, então ela será a ciência de um objeto de qualidade determinada. A arquitetura é evocada como exemplo. Quando surgiu a ciência de construir casas, foi necessário que a distinguisse de outras ciências a ponto de denominá-la arquitetura. O mesmo se aplica à medicina (438d-e):

se agora já percebeste, que era isso que eu então queria dizer, que todas as coisas que tem determinadas qualidades relativamente a um objeto, só por si, apenas consigo se relaciona; se em relação a objetos determinados, tornam-se coisas determinadas. E não digo que o que se relaciona com certo objeto seja semelhante a esse objeto, como por exemplo, que a ciência da saúde e da doença seja saudável ou doentia, e a ciência do mal e do bem, má ou boa. Mas, uma vez que a ciência já não é ciência em si, mas de um objeto determinado - o qual era a saúde e a doença - resultou uma ciência determinada, e isso fez com que já não se chamasse simplesmente ciência, mas ciência médica, segundo a espécie particular em que se tornou. ${ }^{197}$

O argumento diz que se a relação é qualificada, então seu objeto natural tem que ser qualificado; e se o objeto é qualificado a relação precisa ser qualificada. Dizer que a medicina

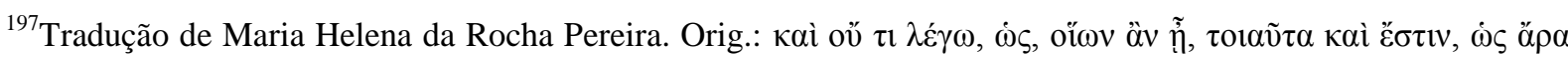

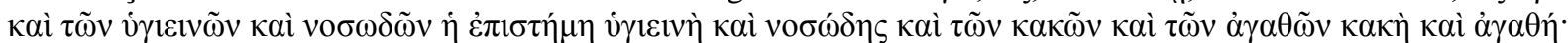

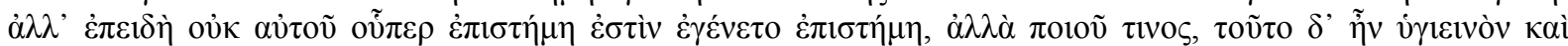

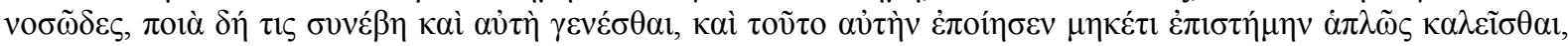

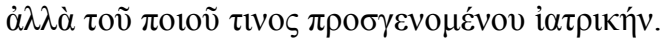


é a ciência da saúde e da doença não significa que ela é sã ou doente, mas ela é qualificada pelo seu objeto de determinação. Este conceito de medicina não é claro aos autores hipocráticos.

O conceito hipocrático de medicina era basicamente nosológico. Como vimos acima, o tratado Da arte conceitua a medicina como a techne que aparta os sofrimentos dos enfermos e alivia os ataques das enfermidades. $\mathrm{O}$ autor do tratado Da medicina antiga define a medicina como a busca, a investigação e a descoberta das dietas que substituíram a alimentação que produzia enfermidades e mortes. Esta descoberta está intimamente relacionada com a culinária (VM. 3). Esta medicina heurística é a única capaz de conhecer algo certo sobre a natureza, e somente ela pode conhecer o que é o homem e o porquê de sua existência ( $V M$. 20). O livro das Epidemias (1. 2. 11) expressa que o conceito medicina engloba três elementos: a doença, o enfermo e o médico. O médico é o servidor da techne, por isso o enfermo deve se opor à doença juntamente com ele.

De acordo com Vegetti (1995, p.23ss) e van der Eijk (2005, p.101-118), apesar de a medicina hipocrática ser nosológica, existem outros testemunhos no Corpus hippocraticum que incluem um tratamento mesmo no estado de saúde. O autor do Das dietas nas doenças agudas (28) diz que é preciso aplicar os conhecimentos da medicina na dieta daqueles que gozam de plena saúde. No tratado Das afecções internas (1) o autor alerta para cuidar da saúde mesmo depois de estar curado, pois em alguns casos a enfermidade retorna e causa a morte.

Voltando a Platão, não poderemos afirmar que ele está tomando partido ou polemizando contra uma determinada corrente de escritos médicos. Vegetti levanta a hipótese que Platão estaria dando uma "extensão malévola" à expressão "saúde e doença", ligando assim com a passagem de 332d-e, onde o médico é capaz de fazer o bem e o mal.

Talvez a solução mais provável fosse procurar pelo sentido da palavra saúde na linguagem corrente da Grécia antiga. Porém, Nadia van Brock (1961, p.147-171) declara que a palavra saúde (hygieia) não era usada de forma distinta pela língua corrente e pela linguagem técnica. Ela possuía basicamente duas extensões semânticas: 
a) Hygieia fazia oposição às expressões: "ficar doente", "estar fraco", "sofrer", danificar, "estar incapacitado", "sentir dor"198. O termo era definido essencialmente pelo estado de oposição entre a doença e a saúde, mas também poderia denotar o estado normal de uma pessoa.

b) O par hygiese hyhiainon também é empregado para descrever o homem que "passa bem" ou o "bem-estar" (Aph. V. 60; Prog.11; Art. 60, 47). Porém, esse sentido de "passar bem" era empregado não somente para o homem, mas poderia ser utilizado para árvores (Hum.11) e seres inanimados.

Provavelmente, Platão está explorando o primeiro sentido da palavra dentro dos propósitos argumentativos do "Princípio da Oposição" e do "Princípio da Qualificação". Então, o fato de definir a medicina como sendo a ciência da saúde e da doença não teria relação direta com as definições hipocráticas. Porém o debate permanece aberto.

\section{O CONCEITO DE MÉDICO.}

Se os conceitos de saúde e medicina, explicitados na República, não se encontram nos escritos médicos dos séculos V e IV a.C, mas parecem indicar uma polêmica, o conceito de médico é uma explicita polêmica às práticas médicas da antiguidade.

Há uma disputa pela autoridade de quem deve ser considerado médico na cidade. Os poetas, os adivinhos, os sofistas, os magos, os médicos, os filósofos da natureza estão envolvidos, direta ou indiretamente neste polemos. De antemão podemos afirmar que não existe uma polaridade nesta briga. Não existe uma mentalidade científica lutando contra uma mentalidade religiosa ou filosófica. Existem médicos contra médicos, e ao mesmo tempo contra filósofos e charlatães. Eles polemizavam contra todos os pretendentes do saber (DESCLOS, 2013, p.204).

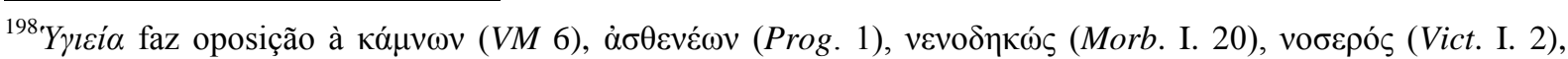

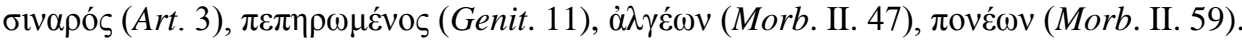


Platão não está à margem desta discussão: desde os diálogos socráticos ele busca responder quem são os bons médicos. No Livro I da República, Sócrates exige que Trasímaco responda quem são os verdadeiros médicos. No Livro III a pergunta sobre o bom médico reaparece ao lado de uma crítica à medicina. Platão responde a esta questão, propondo uma reforma em todo o sistema de saúde que lhe era contemporâneo.

\subsection{Os médicos gregos: busca pela autoridade.}

Os médicos não gozavam de um estatuto profissional equiparável ao moderno. As fronteiras disciplinares permaneciam contestáveis e fluidas (LAKS, 2013, p.67), de forma que Aristóteles cita Diógenes de Apolônia no mesmo plano que os médicos profissionais. Analisando de perto alguns fragmentos dos filósofos tradicionalmente chamados "présocráticos" ou "pré-platônicos", dos séculos V e IV aEN, nota-se que muitos tinham um interesse pelas questões relativas à saúde. Em outras palavras, fazer filosofia implicava fazer medicina. O autor do tratado Da medicina antiga (SCHIEFSKY, 2005, p.1), reage contra a tentativa de fundamentação da prática médica em teorias extraídas da filosofia natural. Ele tenta firmar o estatuto da medicina como uma ciência autônoma, a única capaz de dar explicação do que é a natureza.

Aristóteles, na Política (1282a), relata que o termo "médico" tinha três sentidos: o médico prático (demiourgas), o investigador original que transmite ao médico seus conhecimentos (architetonikos ${ }^{199}$ ), e o homem culto em matéria de medicina (pepaideumenos peri tem techne). Um exemplo deste último "médico" se encontra em Xenofonte (Mem. 4. 2. 10). Eutidemo, um jovem que reuniu uma grande quantidade de obras dos mais renomados poetas e filósofos, foi interrogado por Sócrates se ele almejava ser médico, devido ao número de livros escritos por médicos.

Ao contrário do Egito, na Grécia qualquer um poderia abrir uma "oficina" médica como é contado na anedota sobre Antifonte (2008, p.31-39). Relata-se que ele abriu um consultório na Praça de Corinto com a promessa de tratar as almas tristes através dos discursos. Vendo que não ganhava dinheiro, ele abandonou a clínica.

\footnotetext{
${ }^{199}$ Liddell-Scott traduz como mestre, versado na arte.
} 
Não faltavam ambulantes, magos e charlatães oferecendo a cura para as doenças, mas por outro lado não faltavam pessoas se entregando a qualquer um para se verem livres dos tormentos produzidos pela doença. O tratado Da doença sagrada (2) relata um número de pessoas que praticavam curas:

a) magos (magoi). Originariamente os magos $\left(\right.$ magoi $\left.^{200}\right)$ eram, segundo Heródoto (1. 101) os sacerdotes Persas intérpretes de sonhos. Com o tempo o mago tomou um significado depreciativo de feiticeiro, de uma pessoa dotada de poderes funestos.

b) purificadores (kathartai). O termo purificador $\left(\right.$ kathartai $^{201}$ ) designa um mago que limpava uma vila ou mesmo uma família de um miasma. A peste (loimos) poderia ser entendida como uma imprecação e a doença como uma invasão, uma força externa, divina ou demoníaca ${ }^{202}$. Um exemplo de purificador foi Epimênides de Creta, que, segundo fontes antigas ${ }^{203}$, foi chamado para purificar Atenas de um miasma. Geralmente estes ritos seguiam uma mesma característica (BURKERT, 2001, p.142): 1. experiência do mal e a pergunta pelas causas; 2. intervenção de um mediador; 3. o diagnóstico: causa do mal e o caminho para salvação; 4. atos e ritos de expiação.

c) charlatães (agurtai). Os charlatães $\left(\right.$ agurtai $^{204}$ ) eram sacerdotes mendicantes que vagavam pela Grécia. Os mais famosos eram os metragurtai (LANATA, 1967, p.41) que eram coligados com o culto de Cibele. Jouanna $(1989$, p.8) nota que a crítica contra os magos (magoi) e os charlatães (agurten) está presente também em Sófocles, onde ele os acusa de ignorância da arte e amor ao ganho.

\footnotetext{
${ }^{200}$ Liddell-Scott (1940, p.1071) traduz a palavra magoi, magos como mago; sacerdote e sábio da Pérsia que interpretavam sonhos (Hdt.4.37); encantador, impostor, charlatão. Chantraine (1968, p.1656) também os relaciona com os magos do antigo Irã e das tribos médias, nos gregos o termo designaria um feiticeiro e charlatão. Isidro Pereira (1999, p.354) traduz como mago, feiticeiro.

${ }^{201}$ Kathartai, kathartês é traduzido por Liddell-Scott $(1940$, p.850) e Chantraine (1968, p.478-8) como purificador, mago purificador. Pereira (1999, p.285) traduz como "o que purifica".

${ }^{202}$ Kudlien (1968, p.310) bem observa a natureza da doença como uma punição geralmente resultante da violação de uma lei moral. A doença, segundo ele, adquire nos poetas o estatuto de um demônio, ou melhor, de um automatos

${ }^{203} D L, 1.109-115$; Arist. Ath. I.

${ }^{204}$ Segundo Liddell-Scott (1940, p.16) agúrtai está relacionado com agûris, coleta de ervas (Orfeu L.416), seu significado era impostor, vagabundo, pessoa que implora como vagabundo. Pereira $(1999$, p.8) traduz por mendigo, que recolhe esmola, adivinho, charlatão, que lê a sina.
} 
d) impostores (alazomenes). Os impostores (alazomenes ${ }^{205}$ ) estão etimologicamente relacionados com o verbo alasthai (vadiar).

Giulianna Lanata (1960, p.44) nota a falta de mais uma categoria, os xamãs, encantadores (goes). Os encantadores $\left(\right.$ goes $^{206}$ ) eram homens que operavam prodígios e maravilhas. Lanata (1967, p.44) afirma que este termo é uma designação possível do xamã grego, pois são frequentemente relacionados com Pitágoras e Empédocles. Parece que estes encantadores eram originariamente pessoas que tinham acesso ao mundo dos mortos e eram capazes de invocar a alma dos mortos, de expulsar demônios, de influir magicamente sobre o tempo e assumir os aspectos mais variados. Não se pode esquecer também das práticas de cura que eram realizadas no templo de Asclépio ${ }^{207}$. O culto atraía pobres e ricos, letrados ou não, e gozou de grande popularidade até à antiguidade tardia. Nota-se que o período da ascensão do templo de Asclépio corresponde à fase de ascensão dos médicos hipocráticos ${ }^{208}$. A cura de Asclépio não era uma mágica ou feitiçaria, muito menos um milagre no sentido cristão do termo. Asclépio atuava como um médico ${ }^{209}$ e, se existia alguma cura milagrosa

\footnotetext{
${ }^{205}$ Alazómenes, alazoneia, alazón, são traduzidos respectivamente por Liddell-Scott (1940, p.59-60) como "falsa pretensão, impostor, charlatão, curandeiro". Chantraine $(1968$, p.53) acrescenta que em alguns lugares a palavra adquiriu o sentido de fanfarrão. Pereira (1999, p.24) traduz como charlatão, impostor.

${ }^{206}$ Liddell-Scott (1940, p.856) traduz goes por feiticeiro. Chantraine (1968, p.231) traduz como encantador e afirma que em alguns lugares esta palavra adquiriu um tom pejorativo e se transforma em charlatão. Pereira (1999, p.116) traduz como mago, bruxo, impostor.

${ }^{207}$ No século V aEN o culto a Asclépio cresceu abruptamente. Segundo Burkert (1996, p.155) o culto de Asclépio foi introduzido em Atenas no ano de $420 \mathrm{aEN}$ em consequiência da grande epidemia. Em 366/5 (BURKERT, 1993, p. 417) foi fundado um santuário em honra a Asclépio em Atenas. Os grandes templos de Epidauro e Pérgamo foram construções helenísticas, mas no século $\mathrm{V}$ aEN já havia um altar ao deus em Epidauro (EDELSTEIN, 1998, p. 247), cidade que se foi progressivamente assumindo como "centro espiritual" deste movimento de veneração. Para a datação da deificação de Asclépio, a chegada do culto em Atenas, o templo de Epidauro, o desenvolvimento do culto no período helenística, ver introdução de Vegetti a Opere d'Ippocrate, Burkert (1993, p.417), Lloyd (2009b, p.40-1), Edelstein (1998, p.181-250).

${ }^{208}$ Existem até usos das mesmas terminologias (GIL, 2001, 182-3), como por exemplo, a palavra therapeia que designava tanto os cuidados que se prestam ao enfermo quanto aos atos de culto que se rendem aos deuses; ou mesmo o termo soterios, com fortes conotações religiosas, tem também uma referência medicinal. Lloyd (2003, p.58) nota que a katharsis tinha um duplo serviço no naturalismo hipocrático e na invocação do divino; no primeiro katharsis aparecia um remédio laxante e emético; e no segundo era a purificação de um miasma. Lloyd ainda acrescenta que o contato entre medicina e religião não se deu somente no plano lingüístico, mas também na metodologia, como por exemplo, o papel dos sonhos no tratamento da doença e também o prognóstico, que possuía algumas características da mântica antiga.

${ }^{209} \mathrm{O}$ procedimento de cura se dava através da incubação; um processo que começa quando o doente procura a ajuda do deus. Antes da incubação estavam previstos alguns preparativos como o banho e o sacrifício. Não existem evidências de que o enfermo deveria abster-se de comidas gordurosas, vinho, cerimônia solenes, ritos de purificação, entre outras interdições como noutros santuários. Ao cair da noite, os pacientes eram conduzidos para o lugar onde deveriam esperar pelo deus. Dentro do templo, eles deitavam em um lugar especialmente construído para a incubação chamado de abatonou adyton ${ }^{209}$. O deus aparecia ao doente enquanto ele estava dormindo ou em um estágio intermediário. A epiphania do deus dava-se num ambiente de tranquilidade, ele tinha aparência suave e sua voz era harmoniosa e por vezes ele de um senso de humor. Procedia como um
} 
eram, "milagres médicos". Ele era um excelente cirurgião, aplicava remédios e aconselhava caminhadas ou outro tipo de exercícios ${ }^{210}$.

Existiam também ambulantes, tais como assistentes de médicos, barbeiros, massagistas e parteiras ${ }^{211}$. Originariamente eles se limitavam a assistir o médico no tratamento dos pacientes ${ }^{212}$,mas com o passar do tempo adquiriam experiência e socorriam a população com terapias e tratamentos diversos.

Como os médicos práticos não eram regulamentados por títulos que dessem acesso à profissão, o espírito agônico era grande ${ }^{213}$. O médico (JOUANNA, 1992, p.109) deveria impor-se para conseguir algum sucesso. O primeiro fator de sucesso era sua competência, o segundo era a sua eloquência quando estava diante de um debate público ou quando ele ambicionava o cargo de médico da cidade.

O estatuto de "médico da cidade" parece existir desde o século VI aEN, sendo possível que Demóstenes de Crotona represente o exemplo mais célebre. Na Atenas do século V, parece ter existido um médico público (demosieuon) testemunhado por Aristófanes nos Acarnenses (vv. 1030, 1222) e nas Vespas (vv. 1432). Platão, no Górgias (514d), deixa detalhes sugestivos sobre a eleição do médico público:

médico que trata seus pacientes, dando recomendações ou através de um toque ou mesmo cirurgias. Quando o paciente acordava, ele estava curado e agradecia ao deus através de um sacrifício.Suas ofertas eram simples, tais como "bolos e oferendas, farinha sagrada que ardeu no fogo de Hefesto" (Ar. Pl., 660-1) ou um galo (Pl. Phd. 118a). Baseado nas fontes literárias e nas estelas pode-se deduzir que Asclépio rejeitava a luxúria excessiva.

${ }^{210}$ Cf. Edelstein (1998, p.152-153); T423 Inscriptiones Graecae, IV, 1, 121.

${ }^{211}$ Cf. Mondolfo (1967, p. 90).

${ }^{212}$ Segundo Jouanna (1992, p.173) não existia uma médica no tempo de Hipócrates. A primeira referência a uma mulher médica aparece em uma estela funerária de Fanóstrato datada da segunda metade do século IV aEN A mulher é adjetivada de parteira (maia) e de médica (iatros). Cf. Jouanna (1992, p.175). A medicina estava nas mãos apenas de homens e muitas mulheres tinham vergonha de contar aos médicos o seu real sintoma (Mul. 1. 62). Isso as levava a contar às amigas e às parteiras que, embora não dispusessem de conhecimentos teóricos, tinham muita experiência em uma medicina popular, desde a farmacologia, ao parto e até mesmo o aborto (Tht. 149d). No Corpus Hippocraticum a parteira (maia) aparece raramente; ela é designada pelo substantivo akestris, a curadora, ou pelo particípio substantivado, he ietreousa, ou seja, aquela que trata. O autor do tratado Das carnes (19) testemunha que nos partos difíceis o médico deve trabalhar em conjunto com a parteira, e o autor do Das enfermidades nas mulheres (1.68) fala de um trabalho conjunto do médico com as parteiras. Nos tratados "ginecológicos", o médico não toca nos órgãos sexuais da mulher: ou ele pede para que ela própria o faça ou ele o solicita a outra mulher que o assiste (Nat.Mul. 1. 20-21). Outros assistentes eram personagens mudas, atentos aos comandos dos médicos, tal como no teatro os guardas mudos obedeciam às ordens do rei. Estes homens ajudavam nas cirurgias ou em outros procedimentos como registra o autor do Das articulações, (70). Estes ajudantes são chamados de hyperetai $^{212}$, termo proveniente da marinha (JOUANNA, 1992, p.131) contexto em que designa as pessoas que rema sob ordens, mas o sentido foi estendido a todos que ajudam os assistentes. No tratado Da oficina do médico (2) os hyperetai eram chamados também de médicos, também Platão, nas Leis (IV, 720 a-b), faz menção destes.

${ }^{213} \mathrm{O}$ autor das Epidemias V, 14 polemiza com outros médicos afirmando que "em Larissa, os médicos criam que Hipóstenes tinha peripneumonia, mas não era assim." 
Sócrates: Isso não vale, então, para os demais casos? Se empreendêssemos os afazeres públicos e consultássemos um ao outro como se fôssemos médicos qualificados, decerto nos examinaríamos reciprocamente, eu a ti, e tu a mim da seguinte forma: "Vamos lá, pelos deuses, em que estados se encontra o corpo de Sócrates relativamente à saúde? Há alguém que já se livrou de alguma doença pela intervenção de Sócrates, seja ele escravo ou homem livre? ${ }^{214}$

Sócrates parece estar respondendo a Górgias que no início do diálogo (Grg. 456b) ${ }^{215}$ defendera que se um orador ou um médico fossem obrigados a disputar através do discurso, perante uma Assembleia ou em alguma outra reunião, a designação de médico, certamente o orador seria eleito médico. Através deste diálogo, infere-se um testemunho de que para a eleição de um médico público era necessário: um discurso, e por isso a proximidade entre médicos e sofistas ${ }^{216}$; uma capacidade de curar comprovada; um médico que goze de plena saúde.

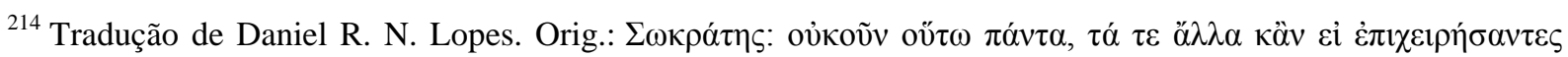

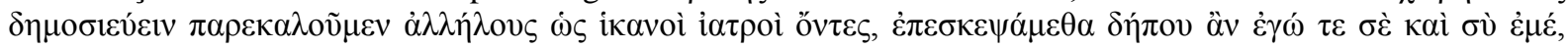

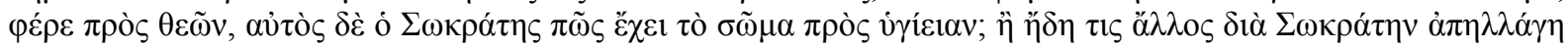

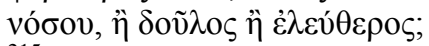

${ }^{215}$ Grg.456b.

${ }^{216}$ A oralidade era um fator importante na divulgação das inovações médicas, e devido a isso muitos tratados tiveram inspiração dos sofistas ou alguns tendo sido provavelmente escritos por alguns deles. Desde o fim do século XIX existiram várias teorias que tentavam relacionar as obras médicas com o trabalho dos sofistas. Theodor Gomperz (2011, p.392) faz uma aproximação entre o tratado hipocrático Peri technes, ou Da ciência médica, com Protágoras. Embora se admita unanimemente que o tratado Da ciência médica é de inspiração sofística, a tese de Gomperz foi refutada por diversos filólogos. Vegetti (1964, p.24) nota que o autor do tratado era um pensador que mostrava predileção pelos problemas das technai em todos os seus aspectos e os seus adversários são os negadores da medicina e das technai em todos os seus aspectos. Ora, Protágoras se encontra entre os mais importantes negadores das téchnai que o Da ciência médica quer refutar, pelo que Vegetti conclui que não pode ser Protágoras o escritor deste tratado. Alguns defenderam que o Da medicina antiga tinha influenciado Protágoras, enquanto que afirmaram que este tratado sofre do relativismo de Protágoras ao rejeitar as generalizações ${ }^{216}$. Guthrie $(1995$, p.158) faz uma aproximação entre Antifonte e o tratado Lei, pois ambos se valem do paralelo entre educação e agricultura. Tenta-se também procurar nos escritos ou na vida dos sofistas algo sobre a medicina. Guthrie (1995, p.159) considera que esta teoria de Górgias foi levada à prática por Antifonte (Frag.11a) em sua "clínica psiquiátrica" em Corinto, quando ele desenvolveu uma arte de consolar paralela à terapia do corpo desenvolvida pelos médicos. Talvez a aproximação mais consciente entre a medicina e o trabalho dos sofistas possa ser notada na composição de tratados do Corpus Hippocraticum. Por exemplo, o tratado Da medicina antiga parece ter sido composto para uma entrega oral. No capítulo 2, o autor utiliza o termo epideiksai para referir a sua atividade. Esta palavra evoca as demonstrações públicas de habilidade retórica. No capítulo 13 o autor faz uma pergunta retórica típica dos debates em público. Por fim, as construções verbais na primeira pessoa do singular estão presentes em todo o tratado, além de que, o autor utiliza (para designar a
} 
Juntamente com as técnicas da retórica, os médicos se valiam da teatralidade nos tratamentos para convencer os pacientes da eficácia do tratamento e ao mesmo tempo impressioná-los.

O médico nunca estava só no exercício da sua arte (JOUANNA, 1992, p.109). O meio do doente e os andarilhos constituíam um público onde se praticavam cirurgias, cauterizações e outros procedimentos como o famoso banco hipocrático. Por vezes o médico é comparado ao $\operatorname{ator}^{217}$ (Lex 1). De acordo com o autor, os falsos médicos são parecidíssimos com atores figurantes das tragédias: possuem aparência, manto e máscara de ator, mas não são verdadeiros atores. Outros médicos criticavam o excesso de teatralidade, principalmente na bandagem, onde alguns tiravam proveito para fazê-las de forma artística ou para encantar a clientela fascinada pela novidade do tratamento ${ }^{218}$. O autor das Articulações (44) critica o excesso de teatralidade e de verborragia no tratamento, tais métodos pareciam uma dissimulação da incompetência.

Devemos entender que havia um claro o interesse por parte do doente em ficar livre de sua enfermidade, e por outro lado, havia também uma tendência agonística que lutava para dar ao enfermo a resposta sobre quem seria a autoridade nos assuntos da saúde: seriam os filósofos da natureza, os magos, os sofistas ou os médicos? Aristófanes (PL. 407) pergunta

sua atividade) sempre os verbos legein e phemi e nunca graphein (SCHIEFSKY, 2005, p.). Jouanna (2012, p.3954) afirma que legein e graphein podem ser sinônimos, porém ele nota que entre os escritos existem diferenças de cursos e discursos: o primeiro consiste em um curso para alunos e outro um discurso epidítico. É aceito unanimemente que os tratados Da arte e Dos ventos foram compostos para disputas orais e possuem forte inspiração dos sofistas. Também a abertura do tratado das Doenças I mostra explicitamente o trabalho agônico

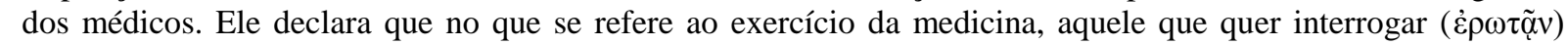

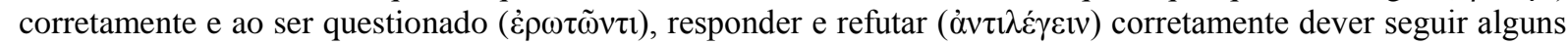
preceitos que ele expõe nos capítulos seguintes. $O$ uso da retórica não se restringia a debates entre médicos, nem a polemicas que eles travavam com os filósofos da natureza, nem às competições ou disputas ao cargo de médico público. O Górgias de Platão (456b) diz que quando o irmão de Górgias, que era médico, precisava convencer algum paciente de algum tratamento, ele chamava Górgias que se valia do poder de persuasão para convencê-lo. Laín Entralgo (1958, p.199-242) não duvida do conhecimento que os médicos tinham dos "salmos mágicos", ou epode, e nem desconheciam o "dizer sugestivo", logos pithanos, contudo, pelo testemunho supracitado e a avaliar pelos escritos do Corpus, parece que nenhum médico da antiguidade se valia dos argumentos sofisticados da retórica para convencer os pacientes. Platão irá relacionar a medicina com a retórica em dois diálogos dedicados a esta: o Górgias e o Fedro. No primeiro ele estabelece um analogon da medicina com a justiça, no segundo ele irá dizer que "o método da arte da medicina é, de certa maneira, idêntico ao da retórica" (270b).

${ }^{217}$ No tratado Da oficina do médico (3), discute-se a quantidade de luz, tanto artificial quanto natural, a posição do cirurgião, a posição correta de seus joelhos e do seu manto, sua distância até o paciente, e a intervenção do paciente. O leitor atento à descrição certamente lembrará a performance de um teatro, principalmente se tiver em mente a alusão ao teatro no capítulo 2 do mesmo tratado, onde a palavra odron, "aquele que atua", ator, no sentido etimológico do termo (JOUANNA, 1992, p.132), é utilizada para o cirurgião.

${ }^{218} \mathrm{O}$ autor de um tratado tardio como o Do médico (4), diz que é necessário deixar de lado as bandagens

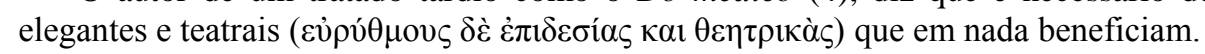


“que médico é que há agora na cidade?" ${ }^{219}$ Platão também vê a necessidade não de mais médicos, mas de bons médicos. Então, é necessário que em um diálogo sobre a politeia ele responda quem deve ser considerado agathoi iatroi.

\subsection{Os agathoi iatroi e a reforma do sistema de saúde.}

Após a crítica à medicina, Platão propõe uma reforma no sistema de saúde, que coincide com a reforma na formação dos médicos. Esta reforma começa no mito de Asclépio, passa pela formação do médico e culmina na terapia da alma. O próprio Sócrates reconhece que existem questões diversas neste discurso (408d). Por isso, é necessário ver cada uma destas partes isoladamente para não perder o fio condutor em meio a tantas propostas que o texto nos traz.

\subsubsection{Ataque ao mito de Asclépio: filho de um deus não é ávido de ganho sórdido.}

Sócrates diz que a techne terapêutica foi feita para os sãos e regrados no seu regime (R. 408b), e os filhos de Asclépio não curariam o doentio por natureza e incontinente mesmo que ele fosse mai rico que Midas. Esta figura parece não chegar ao texto por acaso. Platão poderia estar falando sobre uma possível ligação dos kompsoi asklepiou paidas com a ganância de ganhar dinheiro (408b-c). Para sustentar a hipótese, veremos no texto a seguirum desejo de Sócrates de demolir a tradição mitológica do "patrono" da medicina "ocidental": Asclépio. Neste projeto, ele ataca a terceira Ode Pítica de Pindaro:

Eram bem refinados os filhos de Asclépio, pelo que dizes.

Como se deve, disse eu, ainda que os poetas trágicos e Píndaro não partilhem do nosso parecer. Dizem que Asclépio, por ser filho de Apolo, foi persuadido com ouro a curar um rico que estava com doença mortal, por isso foi fulminado pelo raio. Mas nós, pela base da

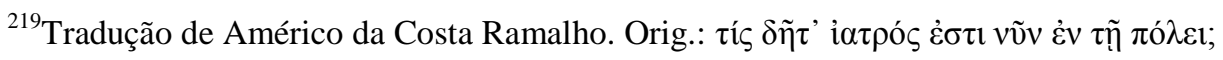


nossa premissa, das duas não aceitamos uma: se era filho de um deus, diremos, não era ávido por dinheiro, se era ávido por dinheiro, não era filho de um deus. 220

Píndaro compôs várias odes para Hierão de Siracusa que governou entre 478 e 467 aEN. As Odes Píticas 1-3 são destinadas ao tirano (ou rei dependendo do ponto de vista) de Siracusa. Estas odes epinícias são consideradas "impuras" (MORGAN, 2015, p.3-5), pois elas possuem duplo significado. As odes de Píndaro evocavam figuras do passado que foram um desastre por causa das suas falhas. A apresentação destes lados obscuros era acompanhada por uma elaboração das virtudes da realeza de Hierão tais como a justiça, cultura, generosidade, $\operatorname{etc}^{221}$.

Edelstein divide a figura de Asclépio em duas, o heroi e o deus. Segundo ele (1998, p.1), para Homero ${ }^{222}$ e para Hesíodo ${ }^{223}$ Asclépio era mortal. Píndaro o descreve como heroi (EDELSTEIN, 1998, p.66) nas Odes Píticas (3. 1-58). Ele relata que Asclépio era filho de Apolo com a mortal Coronis. Ela se entrega a um mortal, então Apolo, tendo descoberto a infidelidade, envia Artemis para matar Coronis. Mas quando o cadáver se encontra na pira, o deus salva a criança ainda por nascer. Asclépio é entregue aos cuidados do centauro Quíron e se torna um grande médico. Por fim, Asclépio faz ressuscitar dos mortos um homem com sua arte, mas em troca de dinheiro (3. 45-60), pelo que Zeus intervém e o mata com seu

\footnotetext{
${ }^{220}$ Tradução própria baseada na tradução de Mario Vegetti e Maria Helena da Rocha Pereira. Orig.: $\pi$ óvv

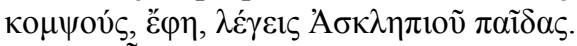

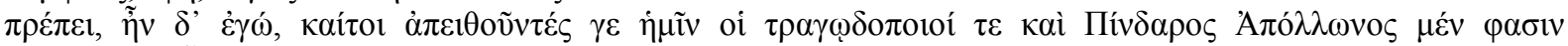

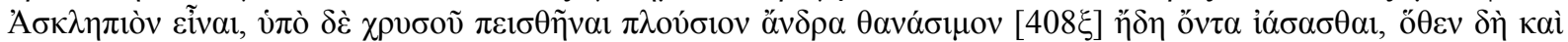

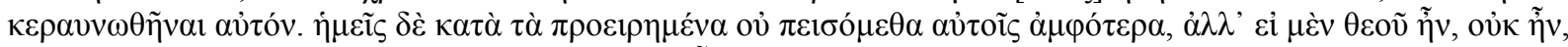

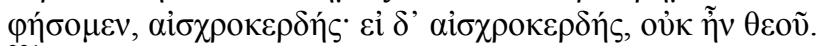

${ }^{221}$ Para as relações entre a corte de Hirão e o mito de Asclépio ver Morgan (2015, p. 260-299). Possivelmente, Hierão estava doente e Píndaro estava dizendo que Asclépio não poderia ressuscitar, mas a poesia poderia imortalizar.

${ }^{222}$ É na Ilíada que o heroi Asclépio é mencionado pela primeira vez. No Catálogo das Náus, Homero (Ilíada 2. 725-733) diz que Asclépio era pai de Podalírio e Macáon, líderes dos homens de Trica, Itome e Ecália. Provavelmente, o Asclépio da Ilíada era como um rei cujos filhos também combateram na Guerra de Tróia. Macáon cura Menelau com um bálsamo que, segundo o autor da Ilíada (4. 219), foi oferecido pelo centauro Quíron ao seu pai Asclépio. Quíron foi considerado o inventor da "fitoterapia". Asclépio foi posteriormente considerado aluno de Quíron. Quanto aos filhos do heroi, duas vezes na Ilíada (4. v.194; 11. v.518) Macáon é chamado de filho de Asclépio, o médico imaculado. Quinto de Esmirna celebra Macáon, afirmando que sua morte na batalha foi uma grande perda para os gregos (Edelstein, frag. T.180). Podalírio, por sua vez, é mencionado na Ilíada somente duas vezes e sempre em conexão com Macáon. Na literatura pós-homérica, Podalírio tratava com a dieta enquanto Macáon tratava com cirurgia e remédio (Edelstein, frag. T.141).

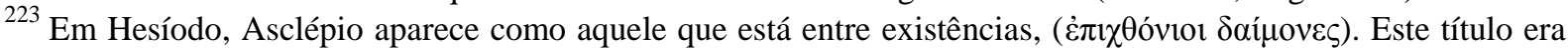
apropriado para o filho de uma mortal com um deus e que depois da morte continua curando os homens em seu templo divino Asclépio (EDELSTEIN, 1998, p.24-34).
} 
relâmpago. Existem muitos problemas com respeito à datação exata da deificação de Asclépio (EDELSTEIN, 1998, p.91-101). Sabemos que no final do século V aEN, seu nome foi ligado com Hygieia, esta fora considerada ora filha, ora esposa de Asclépio ${ }^{224}$. Também nesta mesma data aparece o Hino Homérico a Asclépio ${ }^{225}$.

Sócrates não está de acordo com esta narrativa de Píndaro ${ }^{226}$. Sócrates se refere a ele como filho de Apolo. Ele afirma que se Asclépio era filho de deus, então ele não curava por ganância: e se ele curava por ganância, então ele não era filho de deus. De onde se pode deduzir que: Asclépio era filho deus, logo ele não era interesseiro. Esta argumentação envolve duas noções desenvolvidas na crítica à poesia dos Livros II e III da República. A primeira se refere ao entendimento platônico que os deuses são bons (379a-b) e que eles são a causa do bem (380c). A segunda está relacionada com o poder de influência (386a-c) e o poder mimético que a poesia carrega em si (395b-d). A poesia (também toda arte, a mitologia, o teatro, a performance, a arte da mímesis) exerce uma influência sobre o comportamento das pessoas (MUNIZ, 2011, p.70). O contexto nos leva a afirmar que Platão estava preocupado com os que se dizem descendentes de Asclépio. Então, parece que Platão estaria dizendo que o mito de Píndaro é perigoso, pois levaria os médicos a praticarem a medicina por sórdida ganância.

A Atenas histórica vivia em uma crise financeira e no sistema de saúde. Um tratamento médico custava caro: Eurípedes diz que o pão de cada dia não custa muito caro (El. 426-9), o que pesa no orçamento é hospedar alguém e pagar a conta de um recurso terapêutico. Os médicos buscavam os lugares onde pagavam salários melhores.

Como foi dito no primeiro capítulo, Hipócrates e Platão foram idealizados por Galeno para combater os médicos de sua época. O testemunho de Galeno sobre a ida de Hipócrates à região da Tessália, baseado no tratado Epidemias, está imbricado com a temática de renúncia às riquezas por parte do médico. O médico de Pérgamo tinha interesse em construir esta visão hagiográfica de um Hipócrates "médico de pobres" para denunciar a avareza e a ganância de seus colegas. Contudo as pesquisas recentes sobre as cidades descritas nas Epidemias demonstram a possibilidade de que os médicos hipocráticos não foram profissionais de saúde

\footnotetext{
${ }^{224}$ Edelstein, frag. T.282, T.601.

${ }^{225}$ Asclépio parece ter como função a revelação de alguns oráculos, proteção das famílias, preservação da ordem do cosmos, e curar enfermidades nos sonhos, motivo pelo qual era famoso na Antiguidade.

${ }^{226}$ Deve-se notar que Platão não era o único que criticou Píndaro. Os antigos acusavam de inventar mitos, distorcer fatos para proteger Apolo (ELDELSTEIN, 1998, p.31).
} 
que viajavam indiscriminadamente de cidade em cidade para curar doenças, mas procuravam cidades ricas e populosas em busca de emprego, patronagem e reconhecimento técnico.

O livro III (especialmente o capítulo 14), das Epidemias cita a cidade de Cízico uma antiga colônia dos milésios. Era uma cidade próspera, um grande entreposto comercial, pois fazia parte da rota entre o Mar Negro e o Mar Egeu. Seu território era fértil e produzia madeira, vinho e sal (CHANG, 2005, p.159), além de que pagava altas quantias de tributárias a Atenas ${ }^{227}$. Os médicos visitaram também Ainos e Abdera, cidades excepcionalmente ricas conhecidas pelos seus portos e pela produção de prata. Perinto era uma cidade comercial que os médicos se referiram nos livros II e IV das Epidemias; ela pagou 10 talentos para Atenas durante os V e IV séculos, uma das maiores quantias de toda Grécia. Os médicos hipocráticos ficaram em Tassos por um longo período, de tal forma que esta cidade se tornou o pano de fundo para o Livro I e parte do Livro III das Epidemias. A ilha era rica em vinhedos e peixes, conhecida pelas minas de ouro e prata. A região da Tessália se desenvolveu mais tardiamente tendo em conta que, muitas cidades cresceram rapidamente ao longo dos séculos V e IV. Esta região chamou atenção de todo o mundo grego pela fertilidade de suas terras e pela sua localização estratégica. Isócrates (Antidosis, XV, 155) os chamou de mais prósperos da Grécia e acrescenta que entre eles o sofista Górgias foi o que mais ganhou dinheiro lá.

Um grande número de casos no Livro $\mathrm{V}$ das Epidemias encontra-se registrado em Larissa, a cidade rival de Feras na Tessália (CHANG, 2005, p.165). Em Larissa, onde Hipócrates residiu e provavelmente morreu, os médicos hipocráticos tiveram contato com a ilustre e poderosa família dos Alêuades (JOUANNA, 1992, p.169). No livro das Epidemias pode-se reconhecer entre os nomes dos habitantes de Larissa ali mencionados, membros desta grande família: Diseris (V, 25), Simos (V, 53) e Equécrates (VII, 57). O nome de Aleuas também é mencionado sem indicação da sua cidade de origem; teria sido evocado naturalmente por sua família (II, 1, 10). Em Tassos um dos doentes citados nas Epidemias (I, 8) é Antifon "filho de Critóbulo", que era um theore, ou seja, um magistrado importante que era recrutado dentre as mais poderosas famílias de Tassos na época da oligarquia de 410 (JOUANNA, 1992, p.169). Além da busca por emprego e patronagem em cidades prósperas, pode-se acrescentar a crescente demanda de mão de obra especializada por parte destas cidades. Quando uma cidade cresce, a divisão do trabalho permite que se desenvolvam vários ofícios especializados. Esta cidade busca o conforto e o luxo, pelo que os comércios e

\footnotetext{
${ }^{227}$ Em 442-440, 438, 434, 432 e 431 aEN a cidade pagou 9 talentos; em 429-428 a cidade pagou 8 talentos segundo a Lista de Tributos de Atenas (CHANG, 2005, p.159)
} 
serviços excedem os mínimos exigíveis para a sobrevivência, e por consequiência todos os que contribuem para o conforto da vida se tornam uma necessidade. A ilha de Tassos, por exemplo, atingiu um nível de desenvolvimento e luxo extraordinários (CHANG, 2005, p.168) conforme demonstram os artefatos arqueológicos e iconográficos, cujo testemunho sugere uma similaridade entre ela e a cidade triphosa descrita por Platão na República (369a - 373d)

Deve-se acrescentar que no debate com Trasímaco, Sócrates tinha dito que o verdadeiro médico tem por objetivo tratar dos doentes e não ganhar dinheiro (341c). Todas estas evidências nos levam a questionar se realmente Platão estava sendo inofensivo quando escreveu que Hipócrates de Cós ensinava medicina por dinheiro (Prt. 311b-c). Parece que Platão chega ao âmago da polêmica com os hipocráticos. Agora, ele segue atacando ao centro de todo ensino hipocrático: quem são os bons médicos e como eles devem ser formados?

\subsubsection{Os bons médicos e sua formação.}

Glauco exclama que é necessário ter bons médicos na cidade. Então, ele defende que este bom médico deve ter muita experiência, ou seja, deve tratar o máximo de pacientes sãos e doentes (408c-e):

E isto é tudo correto, eu disse. Mas que dizes disso, ó Sócrates, não pensas que a cidade precisa de bons médicos? E tais devem ser, ao que parece, aqueles que trataram o mais possível de pacientes sãos e doentes, e analogamente os juízes devem ter que lidar com toda classe e toda natureza.

Certamente precisam - respondi -, se eles forem bons. Mas sabes quais eu considero como tais?

Se me explicares, disse.

Vou tentar, disse eu. Tu, porém, colocastes neste discurso questões diversas. 
Como? Indagou.

Os médicos, respondi, mais hábeis são aqueles que começaram desde a infância aprender a técnica, de um lado a ter tratado um grande número de corpos e nas piores condições possíveis, de outro lado sofreram cada doença, não tendo a si mesmo uma natureza sã. Não penso que curam o corpo pelo corpo (porque não consentiria que o próprio corpo possa jamais se enfermar ou se tornar enfermo), mas o corpo pela alma, e se a alma está ou vier a ficar enferma, não pode cuidar bem de qualquer coisa que seja. ${ }^{228}$

Sócrates parece ir além de Gláucon. Os médicos devem ser bons (agathous iatrous), mas também hábeis (iatroi deinotatoi). Vegetti (1995, p.3-48), analisando a ocorrência desta expressão nos escritos de Platão, afirma que há uma busca dos bons médicos nos diálogos socráticos. Em parte, isso se deve à craft-analogy, presente no elenchos socrático. De outra parte, existia um debate vivo sobre quem seriam os bons médicos.

Nadia van Brock (1961, p. 9-17), ao analisar os nomes dos médicos na literatura grega, constata que a expressão ieter agato se encontra pela primeira vez na Ilíada (2. 732) e foi aplicada aos filhos de Asclépio, Podalírio e Macáon. Segundo van Brock, a Ilíada conhecia duas formas da palavra médico: ieter e ietroi. A segunda era destinada ao médico em geral e a primeira era revestida de uma aura mítica. $\mathrm{O}$ termo era empregado, sempre em um contexto laudativo, às vezes qualificado com agatos, e se dirigia ao médico que possuía capacidades preciosas. Platão e seus contemporâneos só utilizam o termo iatros (ietros), que era o termo corrente no grego da sua época.

\footnotetext{
${ }^{228}$ Tradução própria baseada na tradução de Mario Vegetti e Maria Helena da Rocha Pereira. Orig.: ỏ $\rho \theta$ ó $\alpha \tau \alpha, \tilde{\eta}$

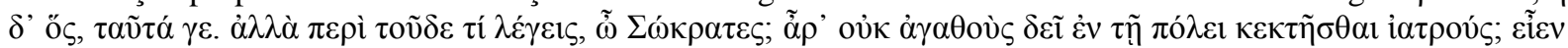

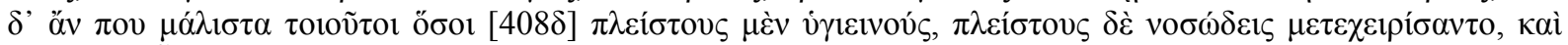

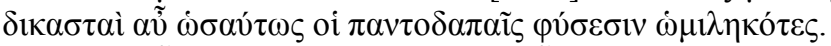

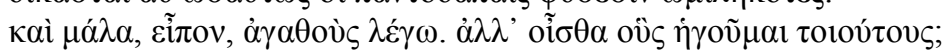

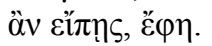

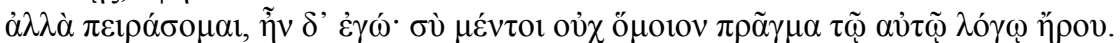
$\pi \tilde{\omega} \varsigma ;$ है $\varphi \eta$.

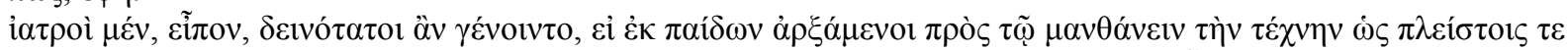

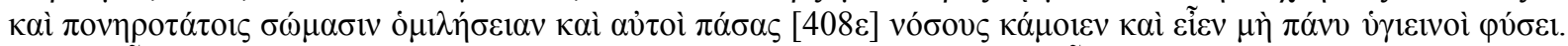

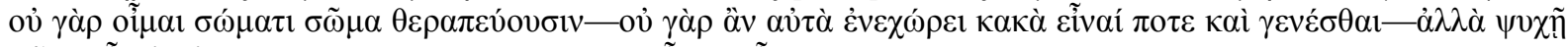

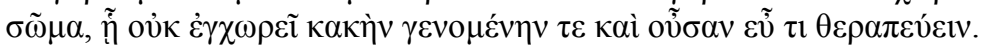


No Corpus hippocraticum, temos a ocorrência do termo jônico ietros, que significava médico e possuidor de alguns conhecimentos. No termo ietros está implicitamente o conceito de "homem que sabe" (VM. 7), além disso o termo está em oposição ao demotes (VM. 2), e ao idiotes (VM. 9, 21; De Arte 6; Flat.1). No tratado Da arte $(12,13)$ encontramos ietros como significando o homem que deve conhecer sua arte. Por isso, não se deve estranhar quando deparamos, na literatura antiga, com os termos cheirotechnes, demiourgosou technites sendo aplicados ao médico (van BROCK, 1961, p.16).

Porém, Platão agora coloca na boca de Sócrates uma tentativa (peirasomai) de esboçar um conceito, não de médico, mas de bom médico. O bom médico é:
a) aquele que começou desde a infância;
b) aquele que tratou de vários corpos;
c) aquele que tratou de várias doenças graves;
d) não são sadios, pois foram vítimas das doenças;
e) não curam o corpo pelo corpo, mas o corpo pela alma.

Vejamos cada uma das afirmações. A primeira afirmação parece estar coerente com o plano de paideia dos guardiões que é descrito no início do Livro III (386a), mas também pode ser uma polêmica contra o corporativismo hipocrático (VEGETTI, 1996, p.62-75). Sócrates criticara (405a) o fato de jovens honrarem a medicina e se ocuparem "fervorosamente" dela. Não faltavam jovens que pagavam aos médicos para aprenderem a sua técnica. Além do testemunho do Protágoras (311b-c), o Juramento hipocrático, segundo Jouanna ${ }^{229}$ (1992, p.72-4), assinala uma revolução no interior das práticas médicas na Grécia, particularmente na abertura da escola médica primitivamente reservada a uma família (Pl. Lg. 720a-b). Esta abertura precisava de uma garantia, que se encontrava no Juramento. É possível que ele fosse

\footnotetext{
${ }^{229}$ Jones (1923, p.291) afirma (pelo contrário) que a exata relação do Juramento com a história da medicina é desconhecida e provavelmente impossível de se conhecer. Jones $(1945$, p.14) também vê com cautela a posição de Edelstein (1960, p.3-64), segundo a qual o Juramento hipocrático foi feito por comunidades pitagóricas do século IV, (essa ideia de relacionar o Juramento com comunidades esotéricas está presente em Szlezák, 2009, p.18). Segundo Jones o texto parece ter inúmeras transposições e interpolações, ou seja, nunca saberemos como ele era originalmente. Para um estudo do Juramento, ver também Cairus; Ribeiro Júnior (2005, p. 151-167)
} 
originariamente um contrato entre o médico que ensina e o jovem que aprende, pois o ensinamento não era gratuito. Atualmente, o Juramento é estudado em vistas de construir uma ideia de ética médica na Antiguidade ${ }^{230}$. Contudo isso nos parece anacrônico, pois o Juramento tinha mais uma função de iniciação do que de moralização ${ }^{231}$.

A segunda e a terceira afirmação parecem estar ligadas. Os bons médicos devem ter tratado de várias pessoas, nas piores condições. Aqui ele não descarta a prática no aprendizado da medicina. Mas o que acontece quando o médico trata os doentes nas piores condições? Tucídides (2.47) relata que, durante a peste, era grande a mortandade entre os médicos, pois eles ficavam expostos à ela. $\mathrm{O}$ autor Dos ventos (1), diz que a medicina é útil ao paciente, mas é fatigante ao médico, porque este vê coisas horríveis, toca em coisas desagradáveis, e sofrem com a desgraça alheia. Esta é a face desagradável da arte médica, segundo o autor hipocrático. Para Platão, dizer que os médicos devem tratar de um grande número de corpos em péssimo estado significa dizer que os médicos deveriam experimentar mais o lado desagradável da profissão para uma possível humanização da classe médica.

A quarta e a quinta descrição do bom médico aparecem sob a forma de uma negação. Sócrates diz que o ele deve experimentar as doenças e sua natureza não será sã. Nota-se uma sutileza no texto: os guerreiros da antiguidade eram saudáveis (408a hygieinos), os novos doentes são enfermos por natureza (408b nosode de physei); e os bons médicos não possuem uma natureza saudável (408e me pany hygieinoi physei). O texto pode estar criticando a exigência de que o médico seja saudável (Grg. 514d), bem como toda a estética performativa do doutor e de sua clínica (Off. 3). Mas o texto também pode estar dizendo que não importa se o corpo do médico está ou é são, pois ele não cura o corpo com o corpo. O médico hábil cura o corpo pela alma.

\subsubsection{Os bons médicos e cura do corpo pela alma.}

\footnotetext{
${ }^{230}$ Cf. de Koninck (2007, p.223); Miles (2004, p.55-160).

${ }^{231}$ Jones nota discrepâncias entre o Juramento e outros livros do Corpus hippocraticum, como por exemplo, o tratado Da natureza da criança, (13) onde o médico hipocrático relata casos em que se usam métodos abortivos, contrariando o Juramento. Na realidade, muitos médicos deram drogas a quem pretendia cometer suicídio, administravam remédios abortivos e praticavam cirurgia.
} 
No capítulo 1, discutimos a questão se Platão era um cientista natural. Foi discutido se Platão era o fundador da psiquiatria ou da psicologia clínica. Agora estamos caminhando em direção de uma resposta final à esta questão.

O médico hipocrático não estava alheio à saúde mental dos pacientes. Eles descrevem perturbações das funções mentais e têm um vocabulário específico para elas (van der EIJK, 2009, p. 21). Dentre as doenças descritas no Corpus hippocraticum se encontram não somente a loucura (mania) e a epilepsia, mas também a insônia, o arrancar cabelos, o arranhar-se, as lágrimas (Epid. 1.23).

Existe uma passagem nas Epidemias (6.5.7) em que o autor aconselha o médico a enrolar uma lã em seu dedo, colocando uma gordura quente e apoiar no ouvido dolorido do paciente, deixando parecer que saiu algo de lá, e ele termina dizendo "apate", (engano). Jouanna (1992, p.191-2) vê uma possível "boa mentira", trabalhando com o imaginário do paciente para ajudar na cura.

Ademais, os médicos não desconheciam o poder do diálogo no tratamento. Apesar da interdição do Juramento e da Lei de ensinar medicina aos pacientes, o autor do Das afecções (1), defende que se ensine às pessoas leigas para que cada indivíduo saiba prestar ajuda a si mesmo na hora das doenças. Ainda no capítulo 13 o autor completa dizendo que se um profano souber mais sobre as doenças e sobre os assuntos de medicina, ele não cairá em enfermidades irremediáveis. O testemunho de Platão nas Leis (720c-e) faz referência a dois tipos de médicos, fazendo supor que existiam duas clientelas e seus respectivos médicos, ou seja, o médico dos escravos que nada lhes comunicava sobre o tratamento, e o médico dos livres que conversava com o paciente e só prescrevia o medicamento com o consentimento destes. Nos tratados das Epidemias encontram-se inúmeras alusões sobre a clientela dos médicos, que totalizam cerca de quatrocentos e cinquenta casos individuais, dentre os quais muitos são anônimos. Outros são pormenorizados, descritos de diferentes formas sendo até possível determinar a origem social do enfermo. Quanto aos escravos, não é possível fazer uma reconstituição precisa da quantidade devido à ambiguidade da palavra pais que pode significar tanto "criança" quanto "escravo". Nas Epidemias, encontra-se também uma grande quantidade de testemunhos da profissão dos pacientes. Geralmente a menção da profissão se faz quando ocorreu um acidente de trabalho, como por exemplo, um sapateiro que se fere acima do joelho (Epid. 5. 45), um cerâmico cai do forno (Epid. 4. 20), etc. A maior parte 
destas profissões são modestas (JOUANNA, 1992, p.168) e tais testemunhos transparecem a imagem de um médico que não deixava de cuidar de uma clientela pouco afortunada ${ }^{232}$.

Todos estes exemplos de profissão, estado social, estado de saúde, demonstram uma comunicação entre o médico hipocrático e o paciente. Apesar de não haver notícias de um manual sobre a interrogação do doente na época de Hipócrates, saber interrogar e ouvir o doente constituía uma virtude entre os médicos (Epid. 6. 2. 24). Por outro lado, a resposta do doente é um guia para o médico na condução do tratamento, assim o diálogo atento é uma peça importante, um trabalho de equipe ${ }^{233}$ entre o médico e o doente para combater a doença.

Laín Entralgo (1958, p.199-241), conclui que o médico hipocrático não desconhecia a importância de uma "psicoterapia". Ele acrescenta que os hipocráticos conheciam bem a eficácia somática da vida psíquica e souberam utilizá-la terapeuticamente. Porém, os médicos hipocráticos não tinham uma categoria que diferenciasse enfermidade física de enfermidade mental (van der EIJK, 2009, p.21). Eles localizavam os processos mentais em órgãos específicos (Morb.Sacr. 16), e a saúde mental era discutida em referências aos diversos estados físicos (Vict. 35-36). Platão irá diferenciar a saúde do corpo da saúde da alma, avançando mais que a nosologia hipocrática. E talvez, devamos interpretar o Fedro (270c-d) neste prisma: precisamos ir além de Hipócrates. ${ }^{234}$

Sócrates conta à Cármides (Chrm. 156d-e), que aprendeu um encantamento no exército com um médico trácio de Zalmoxis. Segundo este médico, Zalmóxis afirmara que não se pode curar os olhos sem tratar da cabeça, ou tratar da cabeça sem curar o corpo. Do mesmo modo não se pode curar o corpo sem tratar da alma. Disto se segue uma crítica aos médicos gregos: a maioria das doenças escapa-lhes ao diagnóstico porque descuidam do todo. Ele continua dizendo que alma está na origem do bem ou mal corpóreo.

Esta crítica do Carmides é reformulada na República ao definir o bom médico. Os bons médicos não são os hipocráticos, nem os médicos gregos. Pensamos que aqui Platão está

\footnotetext{
${ }^{232}$ Talvez os autores das Epidemias estejam implicitamente rebatendo a ideia de que os médicos se preocupavam somente com os ricos.

${ }^{233}$ Mas nem sempre este diálogo era sucesso para o tratamento (Fract. 9). Muitos doentes desobedeciam e até mesmo mentiam para os médicos, o que poderia levá-los a acusação judicial. No tratado Do decoro (14) o autor chama atenção para que o médico esteja vigiando os enfermos, pois eles mentem, não seguem o tratamento e depois acusam o médico. Antifonte, na Tetralogia, 3. 1-4, mostra um julgamento cuja a culpa é atribuída a um médico.

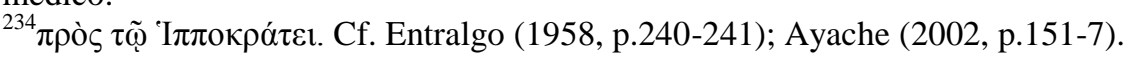


tentando redefinir os rumos da medicina: o médico deve curar o corpo pela alma. Mas o que é a alma? Estamos diante de um grande debate entre os especialistas de Platão ${ }^{235}$. Acreditamos que Platão joga com a polissemia da palavra alma assim como ele faz com várias palavras no Corpus de diálogos. Contudo, nesta passagem ele parece estar usando-a em um sentido específico, ou seja, moral ${ }^{236}$. A saúde é uma questão de moralidade, sustentada por um regime frugal e conduzida pela razão.

\section{ALGUMAS CONCLUSÕES PRELIMINARES.}

A questão da saúde e da doença nunca foi um tema exclusivo da medicina. A doença é uma questão social, pois ela é um dos fatores que forjam o destino dos homens. As pessoas podem ficar doentes através de uma doença endêmica, epidêmica ou pandêmica. Mesmo uma simples e não contagiosa doença em uma pessoa pode mudar toda a rotina e o equilíbrio de uma família ou de uma sociedade ${ }^{237}$. Quando e como se fica doente? Por que ocorrem doenças? Qual é a sua natureza? Estas perguntas conduzem a outra pergunta: quem está na posição de respondê-las? Quem são as autoridades e os experts neste assunto? Médicos, purificadores, magos, parteiras, filósofos, barbeiros, sofistas, disputavam a autoridade para dar a resposta.

A medicina dietética estava tentando se firmar como a única autoridade para explicar o que é a natureza e o homem. Ela "medicalizava" a vida, exaltava a saúde como o maior bem e provocava na sociedade uma divisão de classes. Platão, na República, estava em rota de colisão com as ideias dos hipocráticos.

Platão entra neste debate para dizer o que é a saúde, a medicina e o bom médico:

\footnotetext{
${ }^{235}$ Cf. Robinson (2007, p.73-98); Brisson, Pradeau (2010, p.11-13); Santos (2009, p.35-126); Dodds (2002, p.209-236).

${ }^{236}$ Cf. Robinson (2007, p.85-90); van der Eijk (2009, p.24).

${ }^{237}$ Grmek (1983, p.33) sublinha que o impacto social da doença pode afetar a economia, os movimentos demográficos e os costumes.
} 
a) a saúde, como vimos acima, é a predominância de um elemento sobre o outro conforme a natureza. Alcmeon teria definido a saúde como uma perfeita isonomia dos elementos. Os médicos hipocráticos, inspirados nele, criaram a ideia de uma perfeita mistura dos humores. $\mathrm{O}$ autor do Regime, diz que doença é a predominância de um elemento sobre o outro.

b) medicina é a ciência da saúde e da doença. Este conceito não era comum aos escritos hipocráticos, podendo ter vários significados.

c) os bons médicos são aqueles que desde a infância trataram de vários corpos na pior situação possível e que curam o corpo pela alma.

Devemos notar que quando Platão propõe uma mudança no sistema de saúde e na formação do médico ele não está voltando à Asclépio (pelo menos o de Píndaro), nem à um passado primevo. De forma alguma ele é historicista como pensava Popper. Também na delimitação dos conceitos, Platão não usa ironicamente um conceito de "medicina de Homero" como pensava Strauss. Por fim, Platão não se aproxima de uma medicina "templária" para polemizar contra os hipocráticos como pensa Vegetti (1996, p.62-75), pois não há uma oposição entre medicina "templária" e medicina hipocrática, nem há vestígios textuais na República que sustentam esta afirmação.

Platão não é o criador de uma teoria psiquiátrica, nem psicossomática, pois parece que os médicos hipocráticos possuíam entendimento que algumas doenças tinham origem psicossomática (ENTRALGO, 1958, p.228-9). Platão, de certa forma, "inova" trazendo sua teoria psicológica para o debate da medicina. Curar o corpo pela alma significa aqui curar o corpo pela educação da alma. Um projeto de moralização e educação que envolve a justiça pessoal, a saúde psicológica e uma dieta equilibrada. 


\section{CONCLUSÃO}

Desde a antiguidade, Platão foi ligado à medicina. Os primeiros passos desta ligação não se deram de uma forma sistemática. Surgiu uma interpretação "psicológico-salvífica" (Platão era um médico das almas que tratava da tristeza humana) e outra interpretação "físicobiológica". Estas interpretações, a bem ver, não eram conflitantes. Foi Galeno que nos legou uma ideia de que Platão estaria trazendo os conceitos e o vocabulário da medicina hipocrática para sua filosofia. Platão, nas palavras do médico de Pérgamo, foi um grande admirador de Hipócrates, e ele teceu um grande elogio ao método hipocrático no Fedro. Segundo Galeno, Platão copiou de Hipócrates até mesmo a tripartição da alma. Estas ideias passaram pela Idade Média e chegaram até os dias de hoje.

Durante os debates empiristas e racionalistas, os olhares se voltaram para o padrão da ciência grega antiga. A medicina entra na pauta destas discussões. Para saber como era a medicina hipocrática, os classicistas se lançaram à busca do verdadeiro Hipócrates. Primeiro, tentaram descobrir as escolas médicas que lhe eram concorrentes. Depois, procuraram nos escritos de Platão, especialmente no Fedro, o método hipocrático descrito por Sócrates e o relacionaram com as obras do Corpus hippocraticum. Este debate deu origem à famosa Questão Hipocrática.

Entre os platonistas, este debate tomou outra forma. Parte defendia que Platão importava os conceitos da medicina para sua filosofia, outra parte acreditava que Platão mudou de opinião sobre a medicina durante sua vida. Também, não faltaram aqueles que atacaram Platão, acusando-o de uma engenharia social, a qual usaria a medicina para os interesses do estado. Isso gerou um contra-ataque daqueles que estavam dispostos a fazer uma apologia a Platão, afirmando que ele tinha a intenção de ironizar, e às alusões à medicina queriam dizer o contrário daquilo que está nos diálogos.

Visitando as páginas dos quatro primeiros livros da República, constatamos que, apesar deste diálogo falar sobre vários temas, ele segue um fio condutor: a justiça. Para refutar o pensamento de Trasímaco, Sócrates utilizou a craft-analogy, ou seja, a analogia das technai, 
da qual a medicina tem um papel importante. Até aqui nada parece ter sido conclusivo, pois o Livro I termina com uma aporia.

Nos livros seguintes, Glauco e Adimanto dizem que não foram convencidos completamente pela sua argumentação de Sócrates e apresentam várias objeções. Sócrates propõe um analogon, uma analogia mais profunda entre a cidade e a alma. Neste analogon, há uma constatação que a cidade está "inflamada". Sócrates, então parece perceber a necessidade de "reeducar" a cidade. Ele propõe um regime dos guardiões, que é saudável, diferentemente da atual situação da Atenas histórica. Segundo ele, a medicina que lhe era contemporânea estava se tornando uma "pedagogia da doença". O termo, como vimos, é irônico, e designava uma medicina que ensinava o homem a fugir de um tratamento doloroso, escapar de responsabilidades para com a cidade e abandonar a filosofia, com a desculpa de estar sempre cuidando da saúde.

Sócrates evoca a figura de Heródico de Selimbra como sendo o paradigma da atual medicina. Apesar de não podermos identificar com clareza quem foi Heródico e quais suas ideias, verificamos, em Aristóteles e nos escritos hipocráticos, que ele era uma personagem muito criticada na época. Platão parece estar dizendo que este a quem os médicos criticam é exatamente o representante da medicina.

Sócrates não está propondo uma volta à medicina de Homero, mas ele apresenta uma reforma no sistema de saúde. Esta reforma começa nos mitos "fundadores" da medicina: Asclépio. Asclépio não poderia ser como Píndaro descrevera: ávido por dinheiro. Se fosse assim, ele não seria filho de um deus. Assim também, os asclepíadas não deveriam se mostrar gananciosos por dinheiro. Através dos testemunhos de Eurípedes, de Aristófanes e das cidades descritas nos livros das Epidemias, os médicos buscavam grandes centros onde eles teriam maior chance de exercer sua profissão e também ganhar mais dinheiro. Asclépio era um político, pois sua medicina se preocupava com as pessoas sadias e que seguiam um regime são, conforme a natureza. Esta medicina serve para curar as doenças sazonais e ferimentos, mas não se presta a servir uma cidade que produz cada vez mais novas doenças devido à sua incontinência e desregramento. Então, quem seriam os bons médicos na cidade? Eles são os que desde a infância tratam das pessoas e que curam o corpo pela alma.

No Livro IV, Platão segue o analogon entre cidade e alma. Ele define a medicina como a ciência da saúde e da doença. Depois, para estabelecer um conceito provisório de 
justiça e de atos justos, Sócrates evoca a saúde. Segundo ele, a saúde é a predominância de um elemento sobre os outros, conforme a natureza.

Este modelo de bom médico, de medicina e de saúde era estranho aos conceitos hipocráticos. O vocabulário da medicina se valia de palavras que tinham um forte estreitamento com a política. Platão parece estar fazendo com que os conceitos da medicina estejam mais próximos dos seus propósitos políticos (entendendo política em um sentido mais amplo).

A conclusão que chegamos foi que, nos quatro primeiros livros da República, Platão não está importando conceitos e palavras da medicina de sua época para sua filosofia. Parece mais que ele está polemizando contra os médicos e contra todas as conseqüências que esta medicina estava trazendo para a cidade. Esta medicina, que surgia no século $\mathrm{V}$ aEN, se consolidava com o nome de dietética. Ela trazia um slogan, muito conhecido nas rodas populares, que dizia: a saúde é o maior bem do ser humano. Esta dietética controlava todos os aspectos da vida do ser humano: a comida, os banhos, as bebidas, as relações sexuais e os exercícios. Mas o que parece ser ainda pior: esta nova terapia dividia o tratamento entre os menos favorecidos e os mais abastados.

A dietética se afirmava como um desenvolvimento da culinária, pois através dos alimentos o homem viu o que deveria comer em momentos de debilidade. Porém, desde a antiguidade, as formas de produção e acesso aos alimentos (CRAIGH, 1995, p. 393) escondem subrepticiamente o padrão de vida das populações. No Regime, encontra-se uma longa lista de alimentos, alguns eram comuns aos gregos e outros não (WILKINS, 2005, p. 121-134): o bolo de cevada ou maza era comum a todos, mas as pessoas ricas comiam de forma melhor; os peixes incluem os de grande porte, aparentemente caros; os oroboi, ervilhas amargas, foram utilizados para gado. O testemunho de Ateneu e de Galeno atestam uma demanda crescente por alimentos novos e cada vez mais a cidade se via cativa da necessidade de cozinheiros que oferecessem a uma elite pratos requintados e prazerosos na antiguidade tardia.

A crítica de Platão nestes quatro primeiros livros de República gira em torno das consequencias políticas das novas práticas terapêuticas. Platão propõe uma reorientação na medicina e nos médicos. Contudo a polêmica não acaba nestes livros. Nos livros que se seguem Platão irá falar do conhecimento. Esta teoria enfrenta enormes dificuldades, pois ela 
está ligada com a famosa "Teoria das Ideias" e do conhecimento do Bem. É possível que o alvo das críticas seja a teoria "epistemológica" dos sofistas, mas parece que nos Livros VI e VII a medicina perde totalmente seu estatuto de techne.

No Livro IX, Platão volta ao tema da justiça e tenta responder, definitivamente, Glauco e Adimanto. Nestes dois últimos livros, a medicina está relacionada com as ideias da alma, doença e aos prazeres, bem como uma noção muito debatida no Corpus hippocraticum: plerosis e kenosis. A saúde volta a cena e, de uma forma mais profunda, ela é redefinida. Porém, devido à complexidade dos assuntos, à extensão e aos limites desta dissertação, estes próximos livros serão tema de uma investigação futura. 
APÊNDICE $1^{238}$

\begin{tabular}{|c|c|c|}
\hline \multicolumn{2}{|c|}{ TRADADO HIPOCRÁTICO } & DATA APROXIMADA \\
\hline \multicolumn{3}{|c|}{ Escritos de caráter geral } \\
\hline 1. Juramento & (Iusiurandum; Horkos) & $\begin{array}{l}\text { Data incerta: séc. V ou IV } \\
\text { aEN. }\end{array}$ \\
\hline 2. Lei & (Lex, Nomos) & Provavelmente séc. IV aEN. \\
\hline 3. Da arte & (De artes, Peri technes) & Fim do século $\mathrm{V}$ aEN. \\
\hline 4. Da medicina antiga & $\begin{array}{l}\text { (De prisca medicina, Peri } \\
\text { archaies ietrikes) }\end{array}$ & Fim do século $\mathrm{V}$ aEN. \\
\hline 5. Do médico & (De medico, Peri ietrou) & $\begin{array}{l}\text { Data incerta. Provavelmente } \\
\text { no período helenístico ou } \\
\text { início da era cristã. }\end{array}$ \\
\hline 6. Do decoro & $\begin{array}{l}\text { (De habitu decenti, Peri } \\
\text { euschemosynes) }\end{array}$ & I ou II séc. dEN. \\
\hline 7. Preceitos & (Praecepta, Parangeliai) & $\begin{array}{l}\text { Data incerta. Provavelmente } \\
\text { no período helenístico. }\end{array}$ \\
\hline 8. Aforismos & (Aphorismi, Aphorismoi) & $\begin{array}{l}\text { O tratado conserva material } \\
\text { antigo, mas a redação não é } \\
\text { anterior ao século IV aEN. }\end{array}$ \\
\hline \multicolumn{3}{|c|}{ Escritos com conteúdo anatomo-fisiológico } \\
\hline 9. Anatomia & (De anatomia & Data incerta. Provavelmente \\
\hline
\end{tabular}

${ }^{238}$ Seguimos aqui a classificação temática de Garcia Gual (1983, p.23-25) e a datação de Jacques Jouanna (1992, p.526-563). Littré (1839, p.292-439) divide o Corpus Hippocraticum em classes pelo critério de autenticidade. A classificação de Littré possui alguns problemas quanto à autoria dos escritos, pois que existem diversas controvérsias em relação a muitos dos que o autor considera autênticos. Já a classificação de Garcia Gual, ela enfrenta outros problemas já identificados por Lloyd (2003, p.42). Temas como patologia, fisiologia, cirurgia, embriologia ginecologia e farmacologia, apesar de estarem presentes nos tratados hipocráticos, são inapropriados para classificação, pois nenhuma destas fronteiras disciplinares foi traçada pelos antigos. Além disso, o que estas áreas atualmente representam é muito diferente das práticas e teorias antigas. Apesar disso, optamos por seguir a classificação de Gual por ser mais didática em suas divisões. 


\begin{tabular}{|c|c|c|}
\hline & anatomes) & $\begin{array}{l}\text { no período helenístico ou } \\
\text { romano. }\end{array}$ \\
\hline 10. Do coração & (De corde, Peri kradies) & $\begin{array}{l}\text { Data incerta. Provavelmente } \\
\text { no período helenístico. }\end{array}$ \\
\hline 11. Das carnes & (De musculis, Peri sarkon) & Fim do século $\mathrm{V}$ aEN. \\
\hline 12. Das glandes & (De glandulis, Peri adenon) & $\begin{array}{l}\text { Fim do séc. } \mathrm{V} \text { ou início do } \\
\text { IV aEN. }\end{array}$ \\
\hline 13. Da natureza dos ossos & $\begin{array}{l}\text { (De natura ossium, Peri } \\
\text { osteon physios) }\end{array}$ & Data incerta. \\
\hline 14. Da natureza do homem & $\begin{array}{l}\text { (De natura hominis, Peri } \\
\text { physios anthropou) }\end{array}$ & Fim do séc. $\mathrm{V}$ aEN. \\
\hline $\begin{array}{l}\text { 15. Da geração e Da } \\
\text { natureza da criança }\end{array}$ & $\begin{array}{l}\text { (De genitura e De natura } \\
\text { pueri, Peri gones e Peri } \\
\text { physios paidiou) }\end{array}$ & $\begin{array}{l}\text { Fim do séc. } \mathrm{V} \text { ou início do } \\
\text { IV aEN. }\end{array}$ \\
\hline 16. Do alimento & (De alimento, Peri trophes) & $\begin{array}{l}\text { Data incerta. Provavelmente } \\
\text { no período helenístico devido } \\
\text { ao vocabulário influenciado } \\
\text { pelo estoicismo. }\end{array}$ \\
\hline \multicolumn{3}{|c|}{ Escritos dietéticos } \\
\hline 17. Da dietaou Regime & (De victu, Peri diaites) & $\begin{array}{l}\text { Fim do séc. } \mathrm{V} \text { ou início do } \\
\text { IV aEN. }\end{array}$ \\
\hline 18. Da dieta salutar & $\begin{array}{l}\text { (De salubri victu, Peri } \\
\text { diaites higieines) }\end{array}$ & Fim do séc. $\mathrm{V}$ aEN. \\
\hline \multicolumn{3}{|c|}{ Escritos de caráter patológico geral } \\
\hline 19. Ares, águas e lugares & $\begin{array}{l}\text { (Aere, aquis et locis, Peri } \\
\text { aeron, hydaton, topon) }\end{array}$ & $\begin{array}{l}\text { Segunda metade do século V } \\
\text { aEN. }\end{array}$ \\
\hline 20. Dos humores & $\begin{array}{l}\text { (De humoribus, Peri } \\
\text { chymon) }\end{array}$ & $\begin{array}{l}\text { Data incerta. Provavelmente } \\
\text { séc. IV aEN. }\end{array}$ \\
\hline 21. Das crises & (De crisibus, Peri krision) & Data incerta. Provavelmente \\
\hline
\end{tabular}




\begin{tabular}{|c|c|c|}
\hline & & posterior aos Aforismos. \\
\hline 22. Dos dias críticos & $\begin{array}{l}\text { (De hebdomadis, Peri } \\
\text { hebdomadon) }\end{array}$ & Data incerta. \\
\hline 24. Dos ventos & (De flatibus, Peri physon) & $\begin{array}{l}\text { Segunda metade do séc. V } \\
\text { aEN. }\end{array}$ \\
\hline 25. Prognostico & $\begin{array}{l}\text { (Prognosticon, } \\
\text { Prognostikon) }\end{array}$ & $\begin{array}{l}\text { Segunda metade do séc. V } \\
\text { aEN. }\end{array}$ \\
\hline 26. Predições I & (Praedicta I, Prorretikon A) & $\begin{array}{l}\text { Primeira metade do séc. IV } \\
\text { aEN. }\end{array}$ \\
\hline 27. Predições II & (Praedicta II, Prorretikon B) & Data incerta. \\
\hline 28. Prenoções de Cós & $\begin{array}{l}\text { (Praenotiones } \\
\text { Coacae,Koiakai prognoseis) }\end{array}$ & Fim do séc. IV aEN. \\
\hline \multicolumn{3}{|c|}{ Escritos sobre patologia geral } \\
\hline 29. Epidemias (7 livros) & $\begin{array}{l}\text { (Epidemiorum libri VII, } \\
\text { Epidemion biblia hepta) }\end{array}$ & $\begin{array}{l}\text { Epidemia I e III: fim do séc. } \\
\mathrm{V} \text { aEN Demais livros: } \\
\text { primeira metade do séc. IV } \\
\text { aEN. }\end{array}$ \\
\hline 30. Das afecções & $\begin{array}{l}\text { (De affectionibus, Peri } \\
\text { pathon) }\end{array}$ & Cerca de $380 \mathrm{aEN}$. \\
\hline 31. Das Doenças I & (De morbis I, Peri nouson A) & Cerca de $380 \mathrm{aEN}$. \\
\hline 32. Das Doenças II e III & $\begin{array}{l}(\text { De morbis II, III, Peri } \\
\text { nouson } B, \Gamma)\end{array}$ & $\begin{array}{l}\text { Provavelmente primeira } \\
\text { metade do séc. V aEN. }\end{array}$ \\
\hline 33. Das afecções internas & $\begin{array}{l}\text { (Affectionibus internis, Peri } \\
\text { ton entos pathon) }\end{array}$ & $400-390 \mathrm{aEN}$. \\
\hline 34. Da doença sagrada & $\begin{array}{l}\text { (De morbo sacro, Peri hieres } \\
\text { nousou) }\end{array}$ & $\begin{array}{l}\text { Segunda metade do séc. V } \\
\text { aEN. }\end{array}$ \\
\hline 35. Dos lugares nos homens & $\begin{array}{l}\text { (De locis in homine, Peri } \\
\text { topon ton kat'anthropou) }\end{array}$ & $\begin{array}{l}\text { Data incerta. Provavelmente } \\
\text { séc. IV aEN. }\end{array}$ \\
\hline \multicolumn{3}{|c|}{ Escritos terapêuticos } \\
\hline
\end{tabular}




\begin{tabular}{|c|c|c|}
\hline $\begin{array}{l}\text { 36. Das dietas nas doenças } \\
\text { agudas }\end{array}$ & $\begin{array}{l}\text { (De victu acutorum, Peri } \\
\text { diaites oxeon) }\end{array}$ & Fim do séc. $\mathrm{V}$ aEN. \\
\hline 37. Do uso dos líquidos & $\begin{array}{l}\text { (De liquidorum usu, Peri } \\
\text { hygron chresios) }\end{array}$ & Provavelmente séc. IV aEN. \\
\hline \multicolumn{3}{|c|}{ Escritos cirúrgicos } \\
\hline 38. Da oficina do médico & $\begin{array}{l}\text { (De officina Medici, } \\
\text { Kat'ietreion })\end{array}$ & Provavelmente séc. IV aEN. \\
\hline 39. Das articulações & (De articulis, Peri arthon) & $\begin{array}{l}\text { Fim do séc. } \mathrm{V} \text { ou início do } \\
\text { IV aEN. }\end{array}$ \\
\hline 40. Das fraturas & (De fracturis, Peri agmôn) & $\begin{array}{l}\text { Fim do séc. } \mathrm{V} \text { ou início do } \\
\text { IV aEN. }\end{array}$ \\
\hline 41. Instrumentos de redução & (vectiarius, Mochlikon) & $\begin{array}{l}\text { Fim do séc. } \mathrm{V} \text { ou início do } \\
\text { IV aEN. }\end{array}$ \\
\hline 42. Das feridas na cabeça & $\begin{array}{l}\text { (De capitis vuneribus, Peri } \\
\text { ton en kephalei traumaton) }\end{array}$ & $\begin{array}{l}\text { Fim do séc. } \mathrm{V} \text { ou início do } \\
\text { IV aEN. }\end{array}$ \\
\hline 43. Das úlceras & (De ulceribus, Peri helkon) & $\begin{array}{l}\text { Fim do séc. } \mathrm{V} \text { ou início do } \\
\text { IV aEN. }\end{array}$ \\
\hline 44. Das hemorróidas & $\begin{array}{l}\text { (De haemorrhoidibus, Peri } \\
\text { haimorroidon) }\end{array}$ & $\begin{array}{l}\text { Data incerta. Provavelmente } \\
\text { séc. IV aEN. }\end{array}$ \\
\hline 45. Das fístulas & (De fistulis, Peri syringon) & $\begin{array}{l}\text { Data incerta. Provavelmente } \\
\text { séc. IV aEN. }\end{array}$ \\
\hline \multicolumn{3}{|c|}{ Escritos oftalmológicos } \\
\hline 46. Da visão & (De visu, Peri opsios) & $\begin{array}{l}\text { Fim do séc. } \mathrm{V} \text { ou início do } \\
\text { IV aEN. }\end{array}$ \\
\hline \multicolumn{3}{|c|}{ Escritos ginecológicos e pediátricos } \\
\hline 47. Das doenças das virgens & $\begin{array}{l}\text { (De his quae ad virgines } \\
\text { spectant, Peri parthenion) }\end{array}$ & Provavelmente séc. IV aEN. \\
\hline
\end{tabular}




\begin{tabular}{|l|l|l|}
\hline 48. Da natureza da mulher & $\begin{array}{l}\text { (De natura muliebri, Peri } \\
\text { gynaikies physios })\end{array}$ & Data incerta. \\
\hline $\begin{array}{l}\text { 49. Das enfermidades das } \\
\text { mulheres }\end{array}$ & $\begin{array}{l}\text { (De morbis mulierum, Peri } \\
\text { gynaikeion })\end{array}$ & Provavelmente séc. IV aEN. \\
\hline 50. Da superfetação & $\begin{array}{l}\text { De superfoetatione, Peri } \\
\text { epikyesios })\end{array}$ & $\begin{array}{l}\text { Fim do séc. V ou início do } \\
\text { IV aEN. }\end{array}$ \\
\hline $\begin{array}{l}\text { 51. Do nascimento no sétimo } \\
\text { mêse Do nascimento no } \\
\text { oitavo mês }\end{array}$ & $\begin{array}{l}\text { (De septimestri partu e De } \\
\text { octimestri partu, Perì } \\
\text { heptamenou } \\
\text { octamenou })\end{array}$ & $\begin{array}{l}\text { Fim do séc. V ou início do } \\
\text { IV aEN. }\end{array}$ \\
\hline 52. Da excisão de embriões & $\begin{array}{l}\text { (De embryonis excisione, } \\
\text { Peri enkatatoumes embryou })\end{array}$ & Data incerta. \\
\hline 53. Da dentição & $\begin{array}{l}\text { (De dentitione, Peri } \\
\text { odontophyies })\end{array}$ & $\begin{array}{l}\text { Data incerta. Provavelmente } \\
\text { no início da era cristã. }\end{array}$ \\
\hline
\end{tabular}




\section{APÊNDICE 2}

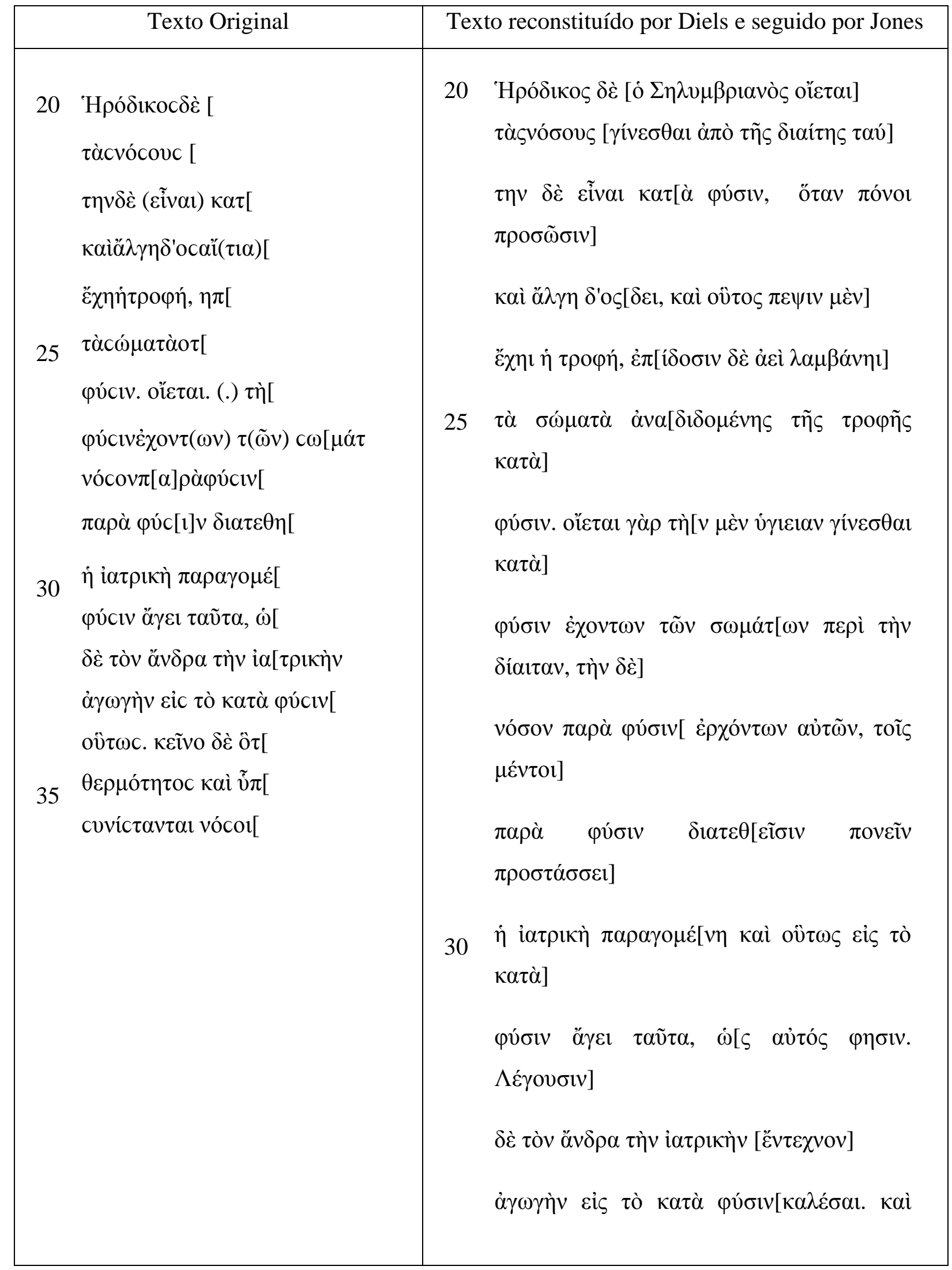




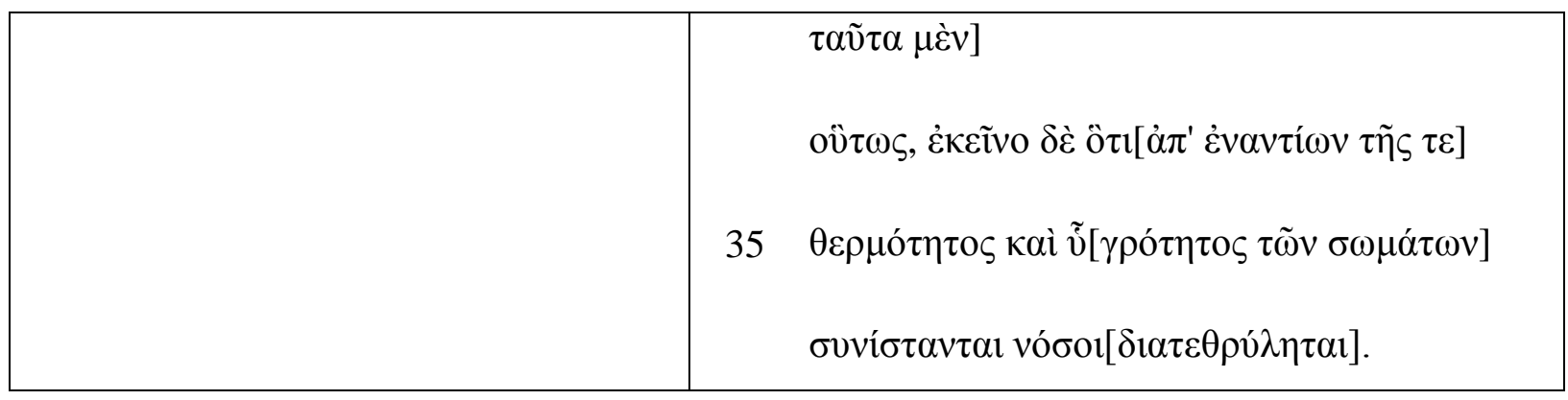




\section{REFERÊNCIAS BIBLIOGRÁFICAS}

\section{FONTES ANTIGAS.}

ANONYMUS LONDINENSIS. Tradução W.H.S. JONES, Cambridge: Cambridge University Press, 2010.

ANTIFONTE. Testemunhos, fragmentos, discursos. Tradução Luis Felipe Bellintani Ribeiro. São Paulo: Edições Loyola, 2008.

ANTOLOGIA PALATINA. Tradução de Miguel Hernandez Galiano. Madri: Editorial Gredos, 1978.

APULEIO. Ouvres Completes D’Apuleé. Tradução de M.V. Bétolaud. Paris: Garnier Frères Libraire, 1836. 2v.

ARISTÓFANES. As vespas, as aves e as rãs. Tradução e apresentação Mario da Gama Cury, $3^{\mathrm{a}}$ edição, Rio de Janeiro: Jorge Jahar, 2004.

. Pluto. Tradução de Américo da Costa Ramalho. Brasília: Editora UnB, 1999.

. Acarnienses. Los caballeros. Introdução, tradução e notas de Luis Gil Fernandes. Madri: Editorial Gredos, 1995.

As nuvens. Tradução de David Jardim Júnior, São Paulo: Ediouro, 1988

ARISTÓTELES. Retórica. Tradução de Quintin Racionero. Madrid: Editorial Gredos, 1994.

Investigación sobre los animales. Traducão de Julio Palli Bonet. Madri: Editorial Gredos, 1992.

Política. Introdução, tradução e notas de Manuela Garcia Valdés. Madri: Editorial Gredos, 1988.

ATENEU. Banquete de los eruditos. Tradução Lúcia Rodriguez Norrega Guillén. Madri: Editorial Gredos, 1998. 
AVERRÓIS. Exposición de la Republica de Platón. Tradução Miguel Cruz Hernandez. $6^{\mathrm{a}}$ edição. Madri: Tecnos, 2011.

CÍCERO. Disputaciones Tusculanas. Tradução de Alberto Medina González. Madri: Editorial Gredos, 2010.

Da República. São Paulo: Ed. Abril Cultural, 1980.

DIÓGENES LAERCIO. Vidas e doutrinas dos filósofos ilustres. Tradução de Mário da Gama Kury. 2 ${ }^{\text {a }}$.ed. Brasília: Editora UnB, 2014.

DIONÍSIO DE HALICARNASSO. Sobre la composicion literária. Tradução de David Hernández de la Fuente. Madri: Editorial Gredos, 2001.

EPICRATES. Fragmentos da Comédia Média. Tradução: Llopis, J.S. et.al. Madri: Editorial Gredos, 2007.

EPICTETO. Dissertaciones por Arriano. Tradução de Paloma Ortiz Garcia. Madri: Editorial Gredos, 1993.

ÉSQUILO. Tragédias. Tradução Jaa Torrano. São Paulo: Iluminuras, 2009.

ESOPO. Fábulas. Tradução de P.Bárdeno de la Peña y J. Lopez Facal. Madri: Editorial Gredos, 1985.

EURÍPEDES. Electra. Tradução Trajano Vieira. São Paulo: Atelie Editorial, 2009.

GALENO. Nuovi scriti autobiografici. Introdução, tradução e comentário de Mario Vegetti. Roma: Carocci editore, 2013. 2009. . Méthode de traitement. Tradução e anotações de Jacques Boulogne. Paris: Gallimard, On the doctrines of Hippocrates and Plato. Edição, tradução e comentário de Phillip de Lacy. $3^{\text {a }}$ edição. Berlin: Akademie Verlag, 2005.

Las Facultades del alma siguen los temperamentos del cuerpo. Tradução de Juana Zaragoze Gras. Madri: Editorial Gredos, 2003a. 
. Tratados filosóficos y autobiográficos. Tradução de Tereza Martinez Manzano. Madri: Editorial Gredos, 2003b.

Oeuvres médicales choisies I: de l'útilité des parties du corps humain. Paris: Gallimard, 1994.

HOMERO. Ilíada. Tradução Haroldo de Campos. São Paulo: Editora ARX, 2008. 2 vol.

HERODOTO. Histórias. Tradução de José Brito Broca. São Paulo: Centauro.

HIPÓCRATES. Tratados Hipocráticos. Edição de Garcia Gual. Madri: Editorial Gredos, 1993-2008. $8 \mathrm{v}$.

On ancient medicine. Tradução, introdução e comentário por M. J. Schiefsky. vol.28. Boston: Brill, 2005.

. Du Régime. Edição e comentário de Robert Joly. Berlin: Academie Verlag, 2003.

. L'ancienne médecine. Introdução e comentário por A.-J Festugière. New York: Arno Press, 1979.

. Opere di Ippocrate. Tradução e introdução por Mario Vegetti. Torino: Tipografico Editrice Torinese, 1965.

Works. Loeb Classical Library. Edição de W. H. S. Jones. Cambridge: Harvard University Press, 1948, 3 vol.

Ouvres Complètes. Edição de Èmile Littré. Paris: Baillière, 1839-1861. 10 v.

ISOCRATES. Discursos. Tradução: Juan Manuel G. Hermida. Madri: Editorial Gredos, 1979-80. 2v.

JUSTINO DE ROMA. I-II Apologias e Diálogo com Trifão. 2a . edição. São Paulo: Paulus, 1995.

MARCO AURÉLIO. Meditações. Coleção Os Pensadores. São Paulo: Ed. Abril Cultural, 1980. 
PÍNDARO. Odas y fragmentos. Tradução de Alfonso Ortega. Madri: Editorial Gredos, 1964.

PLATÃO. A República: ou sobre a justiça, diálogo político. Tradução de Anna Lia Amaral de Almeida Prado. 2 edição. São Paulo: Ed. Martins Fontes, 2014.

. A República. Tradução e organização de J. Guinsburg. São Paulo: Perspectiva, 2012. 2011.

. Górgias. Tradução, introdução e notas de Daniel R. N. Lopes. São Paulo: Perspectiva,

2011.

Timeu-Crítias. Tradução, introdução e notas de Rodolfo Lopes. Coimbra: ECH,

- Carta VII. Introdução Terence Irwin, tradução e notas de José Gabriel Trindade Santos. São Paulo: Edições Loyola, Rio de Janeiro: PUC, 2008.

2008.

La Repubblica. Tradução e comentário de Mario Vegetti. Milão: Bibliopolis, 1998-

La Repubblica. A cura de M. Vegetti. Milano: BUR, 2006.

A República. Introdução, tradução e notas de Maria Helena da Rocha Pereira. 9a. edição. Lisboa: Fundação Calouste Gilbenkian. 2001.

A República. Tradução de Pietro Nassetti. São Paulo: Martins Claret, 2001.

Diálogos. Madri: Editorial Gredos, 1985-1999, 9 v.

. The Republic of Plato. Tradução e notas interpretativas por Allan Bloom. $2^{\mathrm{a}}$. ed. Nova Iorque: Basic Books, 1991.

Obras Completas. $2^{\mathrm{a}}$ ed, Madri: Aguilar, 1980.

Gorgias. Tradução, introdução e comentário de E. R. Dodds. Oxford: Claredon Press, 1959. 
Complete Works. Loeb Classical Library. Cambridge: Harvard University Press, 1917-1927, 12 v.

The Republic of Plato. Editado por James Adam. London: Cambridge University Press, 1902, 2 v.

PLINIO. História Natural. Tradução Josefa Cantó [et all.]. 2 edição. Madri: Catedra Letras Universales, 2007.

PLUTARCO. Consejos para conservar la salud. Tradução de Concepcion Morales Otal y José Garcia Lopez. Madri: Editorial Gredos, 1986.

POETAE LYRICI GRAECI. Editado por Theodor Bergk. Leipzig: B.G. Teubner, 1843.

PORFÍRIO. Astinenza dagli animali. Tradução Giuseppe Girgenti. Milão: Bompiani, 2005.

PROCLO. Commentaire sur la République. Tradução de A.J. Festugière. Paris: Vrin, 2012. 3 vol.

TUCÍDIDES. História da Guerra do Peloponeso. Brasília: Editora UnB, 2001.

XENOFONTE. Ditos e feitos memoráveis de Sócrates. Tradução de Enrico Corvisieri e Mirtes Coscodai. São Paulo: Nova Cultural, 1999.

\section{FONTES MODERNAS}

ALBERT, K. Platonismo: caminho e essência do filosofar ocidental. São Paulo: Edições Loyola, 2011.

AYACHE, L. Hippocrate. Paris: Presses Universitarires de France, 1992.

Hippocrate, l'ultime recurs contre Socrate. In: DIXSAUT, M.; BRANCACCI, A. (org.) Platon sources des présocratiques. Paris: Librairie Philosophique J. Vrin, 2002. p.1517. 
BOURGEY, L. Observation et expérience chez les médecins de la Colletion Hippocratique. Paris: Vrin, 1953.

BOYASK, R. M. Plague and the athenian imagination: drama, history and the Cult of Asclepius. Cambridge: Cambridge University Press, 2007.

BRANDWOOD, L. Estilometria e cronologia. In: KRAUT, R. (org.) Platão. São Paulo: Ideias e letras, 2013. p. 113-146.

BRENNAN, T. A vida estóica: Emoções, obrigações e destino. São Paulo: Edições Loyola, 2010 .

BRISSON, L. O continuun da vida em Platão: dos deuses às plantas. In. FRONTEROTTA, F. Platão: Leituras. São Paulo: Edições Loyola, 2011. p.219-28.

A história da Academia e a tradição platônica. In: .; FRONTEROTTA, F. Platão: Leituras. São Paulo: Edições Loyola, 2011. p.133-139.

A ciência e os saberes. In: ; FRONTEROTTA, F. Platão: Leituras. São Paulo: Edições Loyola, 2011. p.78-92.

.; PRADEAU, J-F. Vocabulário de Platão. São Paulo: Martins Fontes, 2010.

Leituras de Platão. Porto Alegre: EDIPUCRS, 2003.

VAN BROCK, N. Recherches sur le vocabulaire médical du grec ancien. Paris: Librairie C.Klincksieck, 1961.

BURKERT, W. A criação do sagrado: vestígios biológicos nas antigas religiões. Lisboa: Edições 70, 2001. 1993. Religião Grega Clássica e Arcaica. Lisboa: Editora Fundação Calouste Gulbenkian, Platon oder Pythagoras? Zum ursprung des wortes "philosophie".Hermes, Stuttgart, v. 88 , n. 2, p. 159-177, 1960.

BURNET, J. O despertar da filosofia grega. São Paulo: Siciliano, 1994. 
CAIRUS, P. H.; RIBEIRO JÚNIOR, W. A. Textos Hipocráticos: o doente, o médico e a doença. Rio de Janeiro: Editora Fiocruz, 2005.

CAMBIANO, G. Platone e le tecniche. Roma: Editora Laterza, 1991.

La methode par hypothèse em République II. In: DIXAUT, M. (Org.) Études sur la République de Platon: de la science, du bien et des mythes. V. 2. Paris: Vrin, 2005. p. 9-24.

CAMPESE, S. La genesi della polis. In: La Repubblica. Tradução e comentário de Mario Vegetti. Milão: Bibliopolis, 1998-2007. 7 v. p. 285-332.

CASERTANO, G. Uma introdução a República de Platão. São Paulo: Paulus, 2011. Os Pré-socráticos. São Paulo: Edições Loyola, 2011.

CHANG. H. H. The cities of the hippocratic doctors. In: VAN DER EIJK, P.J. Hippocrates in Context. Boston: Brill, 2005, p.154-72.

CHERNISS, H. The riddle of the early academy. New York: Russell and Russell, 1962.

CHROUST, A.-H. Plato's Detractors in Antiquity. The review of metaphysics, Washington v.16, n.1, p.98-118, 1962.

CORNELLI, G. Calcular a saúde: a saúde como equilíbrio de forças na tradição pitagórica. 18. In.: PEIXOTO, M.C.D. A saúde dos antigos: reflexões gregas e romanas. São Paulo, Edições Loyola, 2009, p.33-42

CORNFORD, F. M. Antes e depois de Sócrates. São Paulo: Martins Fontes, 2001. 1987. Principium Sapientiae: los origenes del piensamiento filosófico griego. Madri: Visor,

CRAIK, E. Diet, diaita and dietetics. In: POWELL, A. The Greek World. Londres: Routledge, 1995, p.307-402.

CROMBIE, I. M. Análisis de las doctrinas de Platón: el hombre y la sociedad. Madri: Alianza Editorial, 1962. 
DESCLOS, M-L. Représentation médicale du plublic et publicité de la médecine. In: MACÉ, A. (Org.) Le Savoir Public: la vocation politique du savoir em Grèce ancienne. Paris: Presses Universitaires de Franche-Comté, 2013, p. 201-234.

Aux marges des dialogues de Platon: essais d'histoire anthropologique de la philosophie ancienne. Grenoble: Editions Jérôme Million, 2003.

DIXAUT, M. Platon: le désir de comprendre. Paris: Vrin, 2003.

DODDS, E. R. Os gregos e o irracional. São Paulo: Escuta, 2002.

DOMBROVSKI, D.A. Vegetarianism and the arguments from marginal case in Porphyry. Journal of the history of ideas, Philadelphia, v. 45, p.141-3, 1985.

DUCATILLON, J. Collection Hippocratique. Du Régime, Livre III. Les deux publics. Revue des Études Grecques, Paris, t. 82, f. 389-390, p.33-42, 1969.

EDELSTEIN, L.; EDELSTEIN, E. J. Asclepius: collection and interpretation of the testemonies. Baltimore: The John Hopkins University Press, 1998.

The dietetics of Antiquity. In: TEMKIN, O.; TEMKIN, C.L. Ancient Medicine. Baltimore: John Hopkins Press, 1960, p.303-318.

. The Hippocratic Oath: text, translation and interpretation. In: TEMKIN, O.; TEMKIN, C.L. Ancient Medicine. Baltimore: John Hopkins Press, 1960, p.3-64.

The role of Eryximachus in Plato's symposium.American Philological Association, Philadelphia, v. 76, p.85-103, 1945.

The genuine works of Hippocrates. Bulletin of the history of medicine, Baltimore, v. 7, p. 236-48, 1939.

VAN DER EIJK, P. Os conceitos de saúde mental na medicina e na filosofia gregas dos séculos V e IV a.C (com um breve panorama da Antiguidade tardia). In: PEIXOTO, M. C. D. (Org.) A saúde dos antigos: reflexões gregas e romanas. São Paulo: Edições Loyola, 2009.

Press, 2005.

Medicine and Philosophy in Classical Antiquity. New York: Cambridge Universiy 
FERNANDES, E. Platão e a mereologia da luz. Archai, Brasília, n.11, p. 143-8, jul-dez 2013.

FERRARI, F. Platão e a teoria dos princípios. In: In: BRISSON, L.; FRONTEROTTA, F. Platão: Leituras. São Paulo: Edições Loyola, 2011, p.123-130.

FREDE, M. Essays in ancient philosophy. Minneapolis: University of Minnesota Press, 1987.

FRIAS, I. Doença do corpo, doença da alma: medicina e filosofia na Grécia clássica. Rio de Janeiro: Ed.PUC; São Paulo: Loyola, 2004.

GADAMER, H-G. O caráter oculto da saúde. São Paulo: Editora Vozes, 2011.

GILL, C. O diálogo platônico. In: BRISSON, L.; FRONTEROTTA, F. Platão: Leituras. São Paulo: Edições Loyola, 2011, p.53-71.

GIL, L. Medicina, magia y religión en el mundo griego.Cuadernos de Filología Clásica. Estudios griegos e indoeuropeos, vol.11, Madri, p.178-198, 2001.

GRMEK, M. Les maladie à l'aube de la civilizacion occidentale. Paris: Payot, 1983.

GOMPERZ, T. Os pensadores da Grécia, história da filosofia antiga. São Paulo: Ícone, 2011, vol. 1.

GUTHRIE, W.K.C. Os Sofistas. São Paulo: Paulus, 1995.

História de la filosofia griega. Madri: Editorial Gredos, 1990-1992. 6v.

GRAHAM, D.W. Socrates, the craft analogy, and science.Apeiron, Philadelphia, v. 24, n.1, p.1-24, 1991.

HAUSSLEITER, J. Der Vegetarismus in der antike. Berlin: Verlag, 1935.

HAVELOCK, E. Preface to Plato. Cambridge: Harvard University Press, 1963.

IRWIN, T. Plato's moral theory: the early and middle dialogues. Oxford: Oxford University Press, 1977. 
JAEGER, W. Paidéia: a formação do homem grego. São Paulo: Martins Fontes, 2001.

JOLY, R. Le niveau de la science hipoccratique. Paris: Belles Lettres, 1966.

. La question hippocratique et le témoignage du Phèdre. Revue des Études Grecques,Paris, t. 74, f. 349-350, p. 69-92, jan-jun.1961.

Recherches sur le traité pseudo-hippocratique du Régime. Paris: Édition Belles Lettres, 1960.

JOUANNA, J. Dietetics in hippocratic medicine: definition, main problems, discussion. In: .Studies in Ancient Medicine. Boston: Brill, 2012, p.137-54.

. Hippocrate: pour une archéologie de l'École de Cnide. Paris: Belles Lettres, 2009.

Hippocrate. Paris: Fayard, 1992.

Hippocrate de Cos et le Sacré. Journal des savants, Paris, v.1, n. 1-2, p. 3-22, 1989.

KAHN, C. H. Plato and the Socratic dialogue: the philosophical use of a literary form. Cambridge: Cambridge University Press, 1996.

Proleptic Composition in the Republic, or why Book 1 was never a separate dialogue. The Classical Quarterly, Cambridge, New Series, v. 43, n. 1, p. 131-142, 1993.

KERFERD, G.B. Thrasymachus and justice: a reply.Phonesis, Leiden, v. 9, n. 1, p. 12-16, 1964.

KEYT, D. Platão e a justiça. In: BENSON, H. (org.) Platão. Porto Alegre: Artmed, 2011. p. 318-332.

KIPLE, K.F. The Cambridge Word History of Human Disease. Cambridge: Cambridge University Press, 2008.

KIRK, G. S.; RAVEN, J. E.; SCHOFIELD, M. Os filósofos Pré-socráticos. Lisboa: Fundação Calouste Gulbenkian, 1994. 
KRAUT, R. A defesa da justiça na República de Platão. In: KRAUT, R. (org.) Platão.São Paulo: Ideias e letras, 2013, p. 367-397.

KUCHARSKI, P. La «méthode d'Hippocrate» dans le Phèdre. Revue des Études Grecques, Paris, t. 52, f. 245, p. 301-357, abr-jun 1939.

KUDLIEN, F. Early Greek Primitive Medicine. Clio Medica, Londres, v.3, p. 305-336, 1968.

DE LACY, P. Galen's Platonism. The American Journal of Philology, Baltimore, v. 93, n. 1, p.27-39, 1972.

LAKS, A. Introdução à filosofia Pré-socrática. São Paulo: Paulus, 2013.

LANATA, G. Medicina magica e religione popolare in Grecia, fino all'etá di Ippocrate. Roma: Edizioni Dell'Ateneo, 1967.

LANZA, D. Linguae discorso nell'Atene delle professioni. Napoli: Liguori, 1979.

LEBOUCQ, J. B. G. Une anatomie antique du coeur humain Philistion de Locres et le “Timée” de Platon. Revue des Études Grecques, Paris, v. 57, f. 269-273, p. 7-40, 1944.

LEVIN, S. Plato's rivalry with medicine: a struggle and it's dissolution. Oxford: Oxford University Press, 2014.

LLOYD, G.E.R. Disciplines in the making. Oxford: Oxford University Press, 2009a. Press, 2009b.

In the grip of disease: studies in the greek imagination. Oxford: Oxford University 1991.

Methods and Problems in Greek Science. Cambridge: Cambridge University Press, 1968.

Plato as a natural scientist. The journal of Hellenic Studies, Cambridge, v.88, p.78-92,

Polarity and Analogy: two types of argumentation in early Greek thought. Cambridge: Hackett Publishing Company, 1966. 
LOMBARD, J. Platon et la medicine: le corps affaibli et l'âme attristée. Paris: L'Harmattan, 1999.

LONG, A. Platão e a filosofia helenística. In: BENSON, H. (org.) Platão. Porto Alegre: Artmed, 2011. p. 17-27.

LONGRIGG, J. Greek rational medicine: philosophy and medicine from Alcmeaon to the Alexandrians. London: Routledge, 1993.

LONIE, I.M. The Cnidian treatises of the "Corpus Hippocraticum". Classical Quarterly, Cambridge, v. 59, p. 1-30, 1965.

Cos versus Cnidus and the historians, part 1.History of science, Cambridge, v.16, n.31, p.42-75, mar. 1978.

Cos versus Cnidus and the historians, part 2.History of science, Cambridge, v.16, n.32, p.77-92, jun. 1978.

MONDOLFO, R. Problemas de cultura e educação. São Paulo: Editora Mestre Jou, 1967.

NAILS, D. A vida de Platão de Atenas. In: BENSON, H. (org.) Platão. Porto Alegre: Artmed, 2011. p. 17-27.

. The dramatic date of Plato's Republic. The Classical Journal, Monmouth, v. 93, n. 4, p. 383-96, 1998.

NOTOPOULOS, J. A. Plato's Epitaph. The American Journal of Philology, Baltimore, v. 63, n. 3, p. 272-293, 1942.

NUSSBAUM, M. C. A fragilidade da bondade: fortuna e ética na tragédia e na filosofia grega. São Paulo: Martins Fontes, 2009.

MACÉ, A. Trasymaque de Chalcédoine. In: PRADEAU, J.-F. (Org.) Les sofistes. Paris: GF Flammarion, 2009.

MANETTI, D. Note di lettura dell'Anonimo Londinense - prolegomena ad uma nuova deizione. Zeitschrift für Papyrologie und Epigraphik. Köln, v. 63, p. 57-74, 1986. 
MARX, K. O capital: crítica da economia política. São Paulo: Editora Nova Cultural, 1996. V. 1 .

MESQUITA, P.A. Varia Antiqua: estudos de Filosofia Antiga. Lisboa: Centro de Filosofia da Universidade de Lisboa, 2011.

MILER, S. H. The Hippocratic Oath and the ethics of medicine. Oxford: Oxford University Press, 2004.

MILLER, F. D. A alma platônica. In: In: BENSON, H. (org.) Platão. Porto Alegre: Artmed, 2011. p. 261-275.

MORGAN, K. A. Pindar and the construction of syracusan monarchy in fifth century B.C. Oxford: Oxford University Press, 2015.

MUELLER, I. Método matemático e verdade filosófica. In: KRAUT. R. (org.) Platão. São Paulo: Ideias e Letras, 2013, p.201-35.

MUNIZ, F. Platão e a arte na República. In: XAVIER, D.G.; CORNELLI, G. A República de Platão, outros olhares. São Paulo: Loyola, 2011.

PEIXOTO, M.C.D. Kairos e metron: a saúde da alma na therapeia do corpo. In: A saúde dos antigos: reflexões gregas e romanas. São Paulo: Edições Loyola, 2009.

PENNER, T. Sócrates e os primeiros diálogos. In: KRAUT, R. (org.) Platão. São Paulo: Ideias e letras, 2013, p. 147-199.

PERINE, M. Estudos platônicos: leituras entre o escrito e o não-escrito. In: PERINE, M. (org.) Estudos platônicos: sobre o ser e o aparecer, o belo e o bem. São Paulo: Edições Loyola, 2009, p. 9-26.

PIGEAUD, J. Metáfora e Melancolia: ensaios médicos filosóficos. Rio de Janeiro: Editora PUC - Rio, 2009.

POPPER, K. A sociedade aberta e seus inimigos: o fascínio de Platão. São Paulo: Editora da Universidade de São Paulo; São Paulo: Editora Itatiaia, 1974.

PRADEAU, J-F. Platon et la cité. Paris: PUF, 1997. 
QUINCEY, J. H. Another purpose for Plato, Republic I. Hermes, Stuttgart, n. 109, f. 3, p. 300-315, 1981.

REALE, G. Per uma nuova interpretazione di Platone: alla luce delle "dottrine non scritte". 22a edição. Milano: Edizione Bompiani, 2010. 2002. Corpo, alma e saúde: o conceito de homem de Homero a Platão. São Paulo: Paulus, REEVE, C. D. C. The argument of Plato's Republic. Cambridge: Hackett, 1988.

ROBINSON, T. M. A psicologia de Platão. São Paulo: Edições Loyola, 2007.

ROMILLY, J. Les Grands Sophistes dans l'Athènes de Périclès. Paris: Éditions Fallois, 1988.

ROOCHNIK, D. Of art and wisdom: Plato's understanding of techne. Pennsylvania: Pennsylvania State University Press, 1998.

ROSS, W.D. Plato's theory of ideas. Oxford: Clarendon Press, 1951.

ROSSETTI, L. Introdução à filosofia antiga: premissas filológicas e outras ferramentas de trabalho. São Paulo: Paulus, 2006.

ROWE, C. Modelos de hermenêutica platônica nos séculos XIX e XX. In: MIGLIORI, M.; FERMANI, A. (org.) Platão e Aristóteles: dialética e lógica. São Paulo: Edições Loyola, 2012, p. 383-95. 28-39. Interpretando Platão. In: BENSON, H. (org.) Platão. Porto Alegre: Artmed, 2011. p.

RYLE, R.J. Epictetus. Proceeding of the Aristotelicum Society, Chichester, v. 2, n. 3, p. 123$132,1894$.

SANTAS, G. Understanding Plato’s Republic. Oxford: Wiley-Blackwell, 2010.

SANTOS, J. G. T. Para ler Platão: alma, cidade, cosmo. São Paulo: Edições Loyola, 2009. 
Loyola, 2008.

Para ler Platão: a ontoepistemologia dos diálogos socráticos. São Paulo: Edições

SCARBOROUGH,J. The pharmacology of sacred plants, herbs and roots. In: FARAONE, C.A.; OBBINK, D. (ed.) Magika Hiera: Ancient greek magic and religion. Oxford: Oxford University Press, 1991, p. 138-174.

SCHOFIELD, M. Approaching the Republic. In. ROWE, C.; SCHOFIELD, M. The Cambridge history of Greek and Roman political thought. Cambridge: Cambridge University Press, 2008, p.190-232.

SINGER, P. N. Aspects of Galen's Platonism. In: LÓPEZ FÉREZ (ed.), Galeno: obra, pensamiento e influencia. Colóquio internacional. Madri: UNED, p. 41-55, 1991.

VON STADEN, H. Dynamis: the Hippocratics and Plato. In: BOUDOURIS, K.J. (ed.) Philosophy and medicine. Jonia: Ionia Verlag, 1998, p.262-279.

STRAUSS, L. La Cité et l'Homme. Paris: Biblio Essais, 1986.

Seminar on Plato's Republic - 1957. Universidade de Chicago, 2014. Disponível em: $<$ https://leostrausscenter.uchicago.edu/sites/default/files/Republic1957.finalF.pdf. $>\quad$ Acesso em: 10 de agosto de 2014.

SZLEZÁK, T.A. Platão e a escritura da filosofia: análise de estrutura dos diálogos da juventude e da maturidade à luz de um novo paradigma hermenêutico. São Paulo: Edições Loyola, 2009.

Ler Platão. São Paulo: Edições Loyola, 2005.

TEMKIN, O. Hippocrates in a Word of Pagans and Christians. Baltimore: John Hopkins University Press, 1995.

TRABATTONI, F. Platão. São Paulo: Annablume, 2010.

UNTERSTEINER, M. A obra dos sofistas: uma interpretação filosófica. São Paulo: Paulus, 2012.

Problemi di filologia filosófica. Milão: Istituto Editoriale Cisalpino, 1980. 
. Sofisti: testemonianze e frammenti. Florença: La Nuova Italia Editrice, 1949-1954. 3 vol.

VEGETTI, M. Guida alla lettura della Repubblica di Platone. 5a. edição. Bari: Editora Laterza, 2011.

. Um paradigma do céu: Platão político de Aristóteles ao século XX. São Paulo: Annablume, 2010.

Trasimaco. In: La Repubblica. Tradução e comentário de Mario Vegetti. Milão: Bibliopolis, 1998-2008. 7 v. p.233-256.

Glaucone. In: La Repubblica. Tradução e comentário de Mario Vegetti. Milão: Bibliopolis, 1998-2007. 7 v. p. 151-172.

.Adimanto. In: La Repubblica. Tradução e comentário de Mario Vegetti. Milão: Bibliopolis, 1998-2008. 7 v. p. 221-32.

Techne. In: La Repubblica. Tradução e comentário de Mario Vegetti. Milão: Bibliopolis, 1998-2008. 7 v. p.193-207.

Culpabilidade, responsabilidade e causa: filosofia, historiografia e medicina no século V a.C. In: LONG, A.A. Primórdios da filosofia grega. São Paulo: Ideias e Letras, 2008, p.345-364.

Quindici lezioni su Platone. Torino: Piccola Biblioteca Einaudi, 2003.

Kompsoi Asklepiades: la critica di Platone allá medicina nel III libro della Repubblica. In: BRILL, E.J. (Org.). Studies in the History and historiography of Ancient Philosophy. Danvers: Polyhistor, 1996, p.62-75.

La Medicina in Platone. Venezia: Il Cardo, 1995.

. Technai e filosofia nel "Peri technes" pseudo-ippocratico. In: Atti della Accademia delle Scienze di Torino, Turim, v. 98, p.5-35, 1964.

VLASTOS, G. Socrate: ironie et philosophie morale. Paris: Aubier, 1994. 
The argument in the Republic that "justice pays".The Journal of Philosophy, New York, v. 65, n. 21, p. 665-674, 1968.

WILKINS, J. The social and intellectual context of Regimen II. In: VAN DER EIJK, P.J. Hippocrates in Context. Boston: Brill, 2005, p.121-134.

Food in ancient word. Oxford: Blackwell Publishing, 2006.

XAVIER, D. G. Epékeina tês ousias: o Uno-Bem na República de Platão. In: XAVIER, D.G.; CORNELli, G. A República de Platão: outros olhares. São Paulo: Edições Loyola, 2011, p. 227-238.

\section{DICIONÁRIOS}

AST, F. Lexicon Platonicum: sive vocum platonicarum index. Leipzig: Wiedmann, 1835.

CHANTRAINE, P. Dictionaire étimologique de la langue grecque. Paris: Éditions Klincksieck, 1968.

KÜHN, J-H; FLEISHER, U. Index Hippocraticus. Gottingen: Vanderhoeck and Ruprecht. 1986-1989. 4 vol.

LIDDELL and SCOTT. Greek-english lexicon. Revisado por H. S. Jones. 9a edição. Oxford: Oxford University Press, 1840.

Novas normas de transliteração. Revista Archai, Brasília, Editora UnB, n. 12, p. 193 jan-jun 2014.

PEREIRA, I. Dicionário Grego-português Português-grego. $8^{\text {a }}$ edição. Braga: A. I., 1999. 